\title{
Home-based literacy experiences of severely to profoundly deaf pre-schoolers and their hearing parents
}

\author{
Carlin Lillian Stobbart
}

Submitted in partial fulfilment of the requirements for the degree Masters in Augmentative and Alternative Communication Faculty of Humanities

University of Pretoria

Supervisor: $\quad$ Prof E. Alant

Co-Supervisor: Dr S. Dada

Pretoria

December 2005 


\section{ACKNOWLEDGEMENTS}

This report is dedicated to my husband, Kent and my sons Mark and Rowan. Without their support, I could not have completed this work.

\section{I would like to express my sincere appreciation to the following people:}

- My supervisor, Professor Erna Alant, for her continual interest and guidance as well as for sharing her enthusiasm and knowledge.

- My co-supervisor, Dr Shakila Dada, for her invaluable suggestions.

- Ms Jaqui Sommerville and Ms Karien Malan, Department of Statistics, for their input and assistance with the questionnaire design and statistical analyses.

- The principals, speech therapists, teachers and parents at the schools for the deaf and units for language and hearing impaired children. Thank you to everyone who made suggestions and shared their unique experiences with me.

- Stephne Smit and Ian van den Berg, for their invaluable input in the translation of the questionnaire.

- Desiree Seekola, Odette Swift and Ingrid Parkin for their inspiration and for sharing their enthusiasm for education of the deaf.

- My husband Kent for his help with the visual presentation of the results and for printing the final document.

- Jann Tilbury and Ruth Kuhn for meticulously proofreading the final report.

- My family and my friends for their continual support and encouragement. 


\begin{abstract}
The low literacy levels achieved by deaf children are of ongoing concern to educators and researchers alike. The present research considered emergent literacy as one aspect to consider in the acquisition of literacy skills in deaf children. The aim of this research was to describe the home-based literacy experiences of severely to profoundly deaf preschoolers as provided by their hearing parents. Parents of twenty-nine pre-school deaf children from schools for the deaf were selected to complete a questionnaire. The questionnaire was developed based on the four identified literacy contexts: the physical and functional context, the language context, the affective context and the educational context. The results obtained indicate that the deaf children in this survey are exposed to literacy-rich home environments where they are able to observe literate adult role models. Limitations in the quantity and quality of text-based interaction between the deaf pre-schoolers, their hearing parents and older siblings were identified. The results also indicated that the parents who participated in this research regarded the development of language and communication as more important than the early acquisition of literacy skills. The parents assigned the greatest responsibility in teaching literacy skills to teachers. This study highlights the sensitive nature of early literacy and language learning in young deaf children. Suggestions for further research are presented.
\end{abstract}

Key terms: Emergent literacy, early literacy skills, home-based literacy experiences, severely to profoundly deaf, physical and functional context, language context, affective context, educational context 


\section{OPSOMMING}

Die lae vlakke van geletterdheid in dowe kinders, is ' $n$ voordurende kommer vir beide navorsers en onderwysers. Hierdie navorsing stel voor dat vroeë geletterdheid ' $n$ belangrike punt is om in ag te neem in die ontwikkeling van geletterdheid in dowe kinders. Die doel van die navorsing was om die tuis-geletterdheidservarings, van ernstige tot totale dowe kinders en hul horende ouers, te beskryf. Ouers van nege-en-twintig voorskoolse dowe kinders van verskillende skole vir dowes is gekies om 'n vraelys te voltooi. Die vraelys was spesifiek vir die navorsingsdoeleindes ontwikkel en was op vier kontekste wat met geletterdheid verband hou, gebaseer: die fisiese en funksionele konteks, die taalkonteks, die affektiewe konteks en die onderrigkonteks. Die resultate dui daarop dat die dowe kinders in hierdie studie aan ouerhuise ryk in geletterdheid blootgestel word. Die kinders het die geleentheid om volwasse geletterdheidsmodelle waar te neem. Beperkings in die hoeveelheid en kwaliteit van teks-gebaseerd interaksie tussen die dowe kinders, hul ouers en ouer broers en susters, is waargeneem. Hierdie navorsing dui ook aan dat ouers die vroeë taal- en kommunikasie ontwikkeling van hul dowe kinders as belangriker as die ontwikkeling van vroeë geletterdheid. Die ouers het die meeste verantwoordelikheid vir hul kinders se verwerwing van geletterdheid aan onderwysers toegelaat. Die navorsing beklemtoon verder die sensitiewe verwantskap tussen die ontwikkeling van vroeë taal-en geletterdheidsvaardighede in dowe kinders. Aanbevelings vir verdere navoring word ingesluit.

Sleutelwoorde: vroeë geletterdheid, vroeë geletterdheidsvaardighede, tuis-gabaseerde geletterdheidservarings, ernstige tot totale doofheid, fisiese en funksionele konteks, taalkonteks, affektiewe konteks, onderrigkonteks. 


\section{TABLE OF CONTENTS}

ACKNOWLEDGEMENTS ......................................................................................................... ii

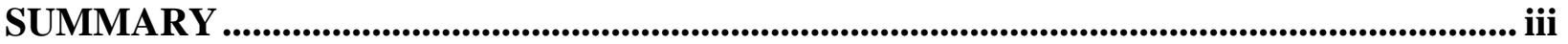

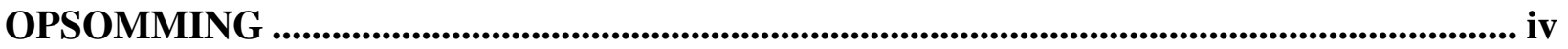

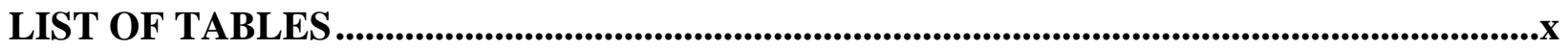

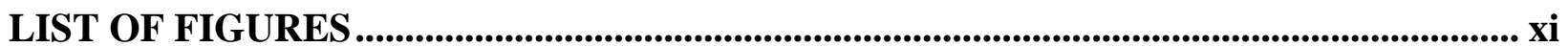

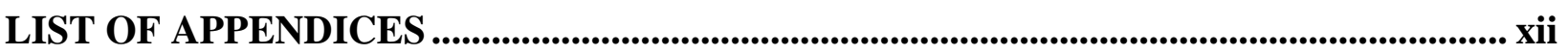

\section{CHAPTER 1}

INTRODUCTION TO THE STUDY

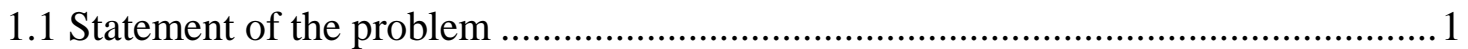

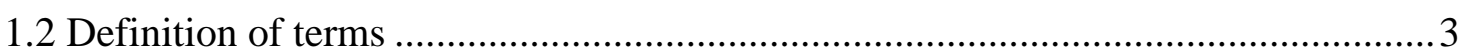

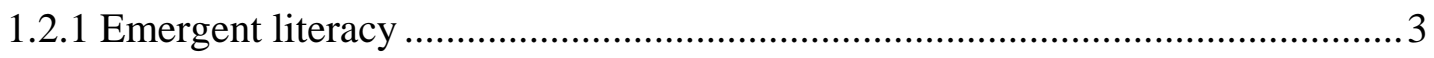

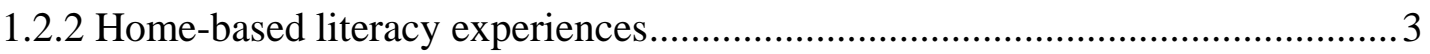

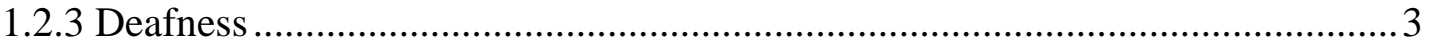

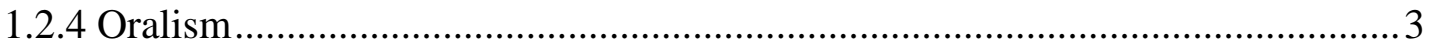

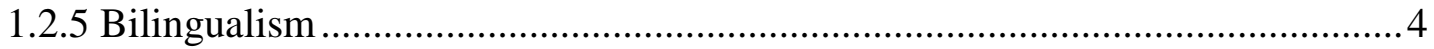

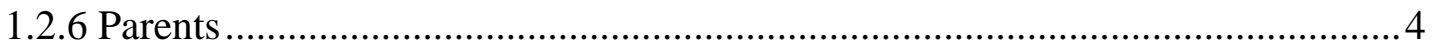

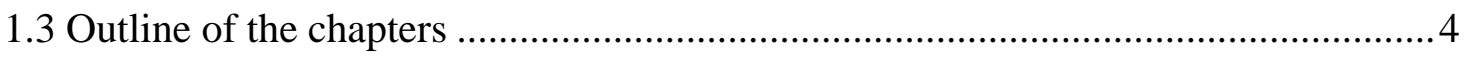

1.3.1 Chapter one: introduction.....................................................................

1.3.2 Chapter two: overview of the literature ....................................................... 4

1.3.3 Chapter three: methodology ......................................................................... 4

1.3.4 Chapter four: results and discussion ............................................................. 4

1.3.5 Chapter five: conclusion and recommendations ..............................................5

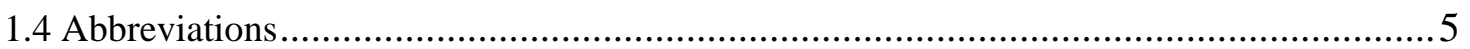

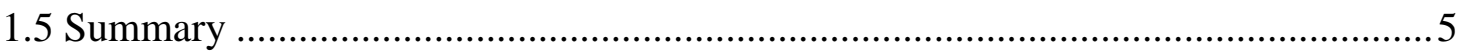




\section{CHAPTER 2}

REVIEW OF THE LITERATURE

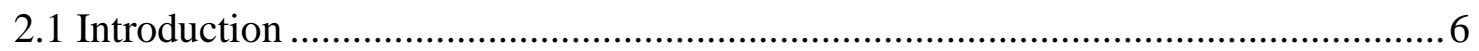

2.2 Emergent literacy as the cornerstone of literacy development................................ 7

2.3 Overview of research studies on emergent literacy relevant to the present research 9

2.4 Factors to consider in the emergent literacy development of deaf children.............15

2.4.1 The role of theories in emergent literacy of deaf children ................................15

2.4.2 The role of language in the emergent literacy of deaf children ........................17

2.4.3 The role of context in the emergent literacy of deaf children.......................... 18

2.4.3.1 The physical and functional context ........................................................20

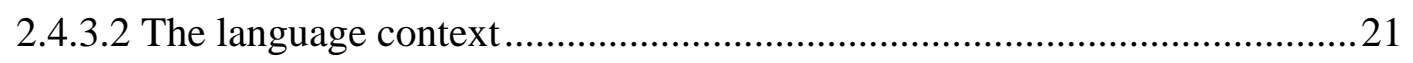

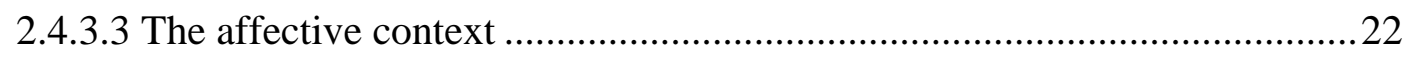

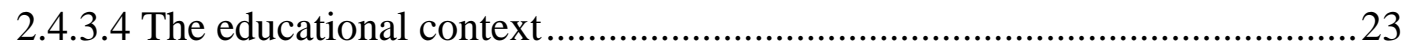

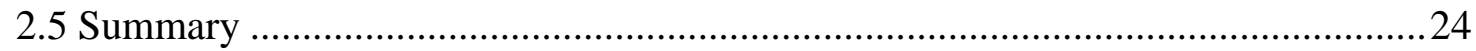

\section{CHAPTER 3}

RESEARCH METHODOLOGY

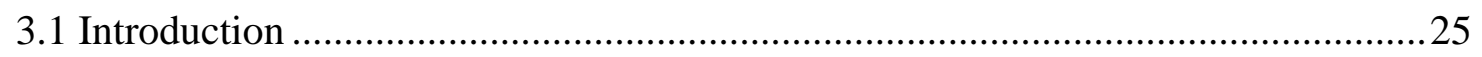

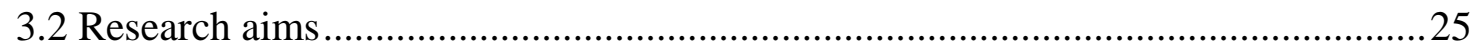

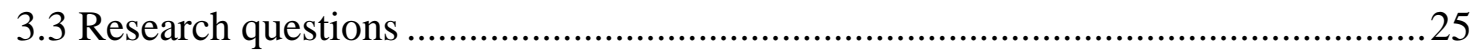

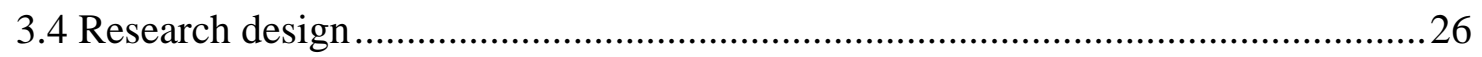

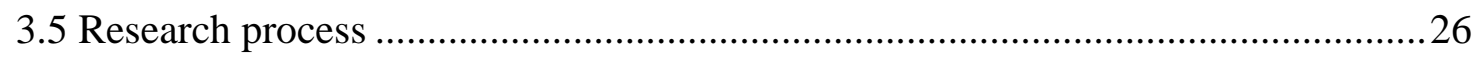

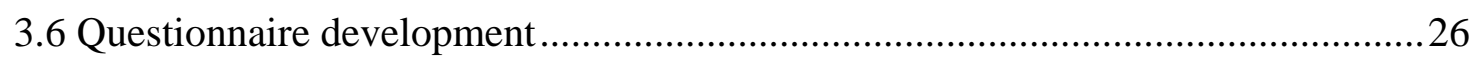

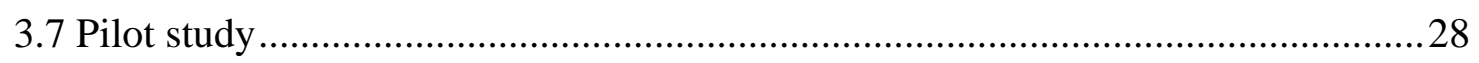

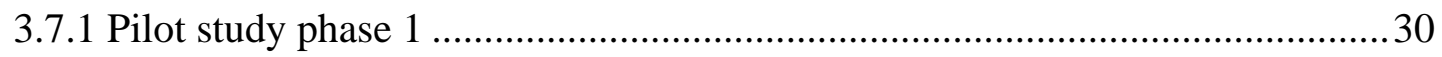

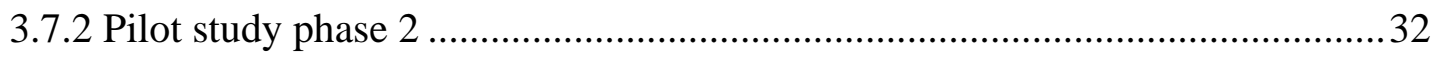

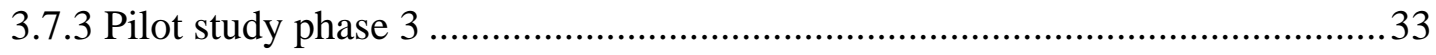

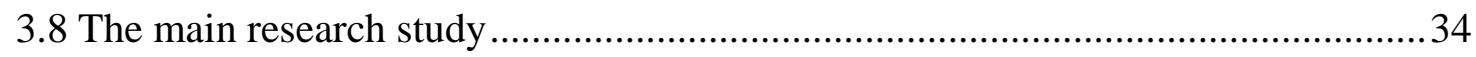

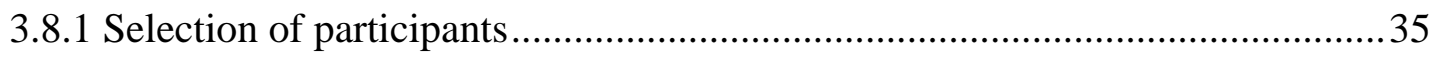

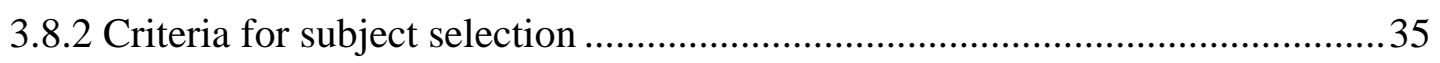

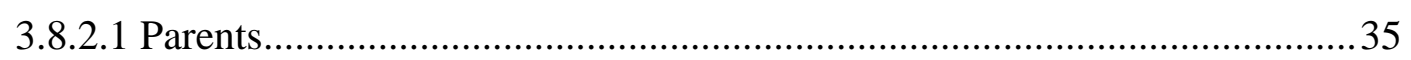

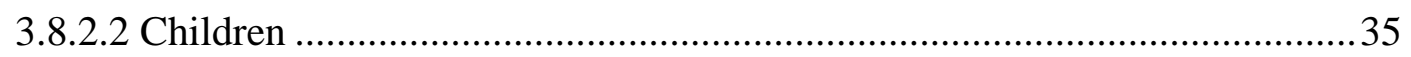




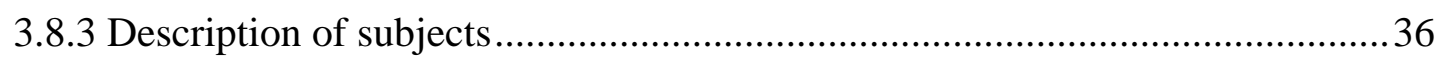

3.8.3.1 Description of parents.............................................................................. 36

3.8.3.2 Description of children ................................................................................ 38

3.8.4 Research sample........................................................................................

3.8.5 Presentation of research participants............................................................... 41

3.8.6 Materials used in the study............................................................................ 43

3.8.6.1 Questionnaire layout.................................................................................. 43

3.8.7 Procedures for data collection......................................................................... 45

3.8.7.1 Preparation for the fieldwork.................................................................... 45

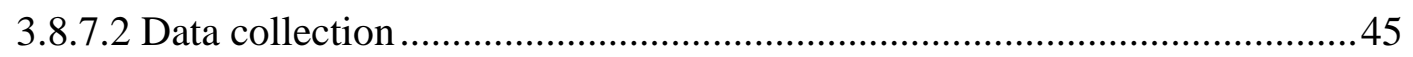

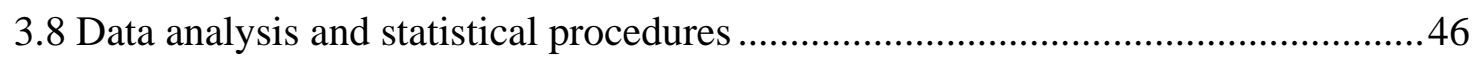

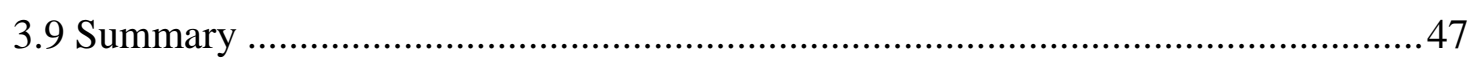

\section{CHAPTER 4}

RESULTS: PRESENTATION AND DISCUSSION

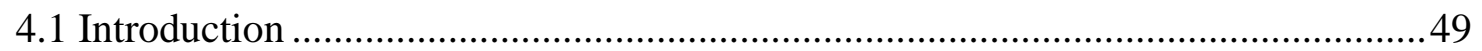

4.2 The physical and functional context...............................................................5

4.2.1 Reading and writing as favourite activities.......................................................50

4.2.2 The nature of the home reading and writing environment..................................53

4.2.2.1 Parents' reading and writing ....................................................................... 53

4.2.2.2 Availability of reading and writing materials ...............................................5 55

4.2.3 The deaf child's early literacy experiences within the physical and functional

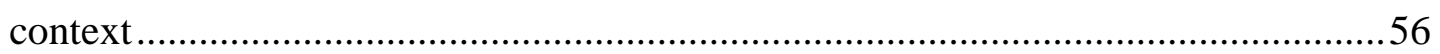

4.2.4 The deaf child's engagement in reading and writing activities .........................59

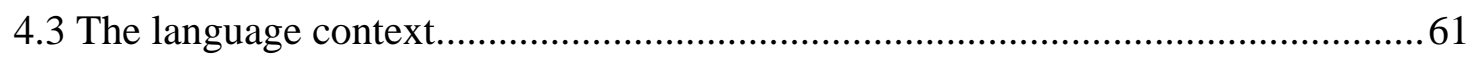

4.3.1 The deaf child's behaviour and communication during story reading activities

4.3.2 Hearing parents' role during story reading activities..........................................64

4.3.3 The role of other family members in the literacy activities of deaf children....66

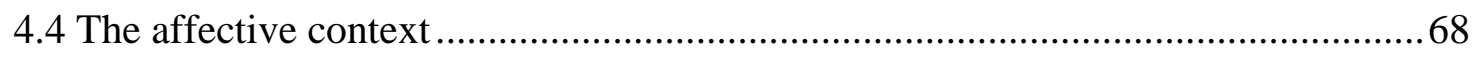

4.4.1 Parents' views on aspects of their deaf children's development .........................68

4.4.2 Parents' allocation of responsibility in their children's literacy development..70

4.5 The educational context........................................................................................ 
4.5.1 Parents' experiences in reading to their deaf children .................................... 71

4.5.2 Parents' experiences of support received from their children's schools............ 72

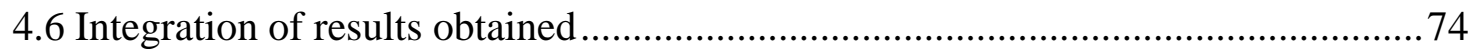

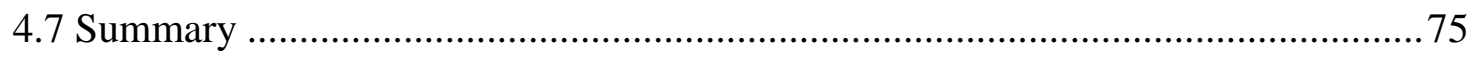

CHAPTER 5

CONCLUSIONS AND

RECOMMENDATIONS FOR FUTURE RESEARCH

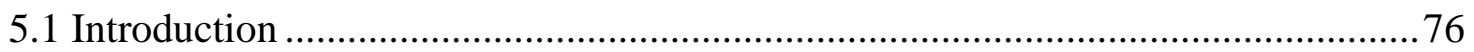

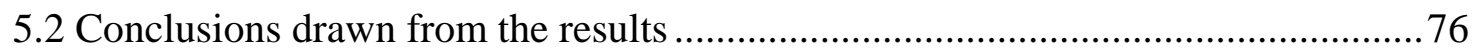

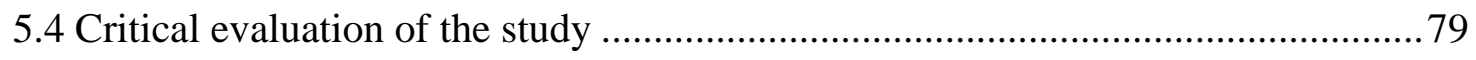

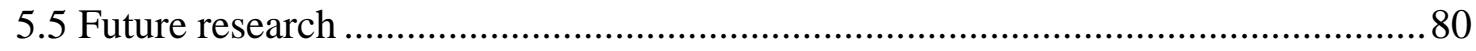

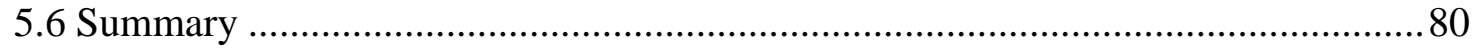

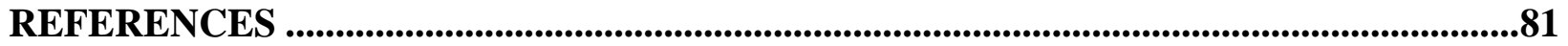

APPENDIX A
DEVELOPMENT AND DESCRIPTION OF QUESTIONNAIRE CONTENT

WITH THEORETICAL JUSTIFICATION.

APPENDIX B

RESULTS OF PILOT STUDY PHASE ONE

ADJUSTMENTS TO THE QUESTION FORMAT, QUESTION FORMULATION

AND RESPONSE FORMAT.

APPENDIX C

RESULTS OF PILOT STUDY PHASE 2

ADJUSTMENTS TO THE QUESTIONNAIRE FOLLOWING THE

TRANSLATION INTO AFRIKAANS .96

APPENDIX D

QUESTIONNAIRE .98 
APPENDIX E

VRAELYS .113

APPENDIX F

COVERING LETTER TO THE QUESTIONNAIRE IN ENGLISH AND

AFRIKAANS. .130

APPENDIX G

LETTER OF PERMISSION TO CONDUCT THE RESEARCH: .134 GAUTENG DEPARTMENT OF EDUCATION. .134

APPENDIX H

ETHICAL CLEARANCE FROM THE UNIVERSITY OF PRETORIA .136

APPENDIX I

CONSENT AND INFORMATION LETTER TO SCHOOLS AND UNITS .137

APPENDIX $\mathbf{J}$

PARENTAL CONSENT LETTERS FOR PARTICIPATION IN THE RESEARCH ......139

APPENDIX K

QUESTIONNAIRE: CATEGORIES FOR OPEN QUESTIONS .143

APPENDIX L

OUTLINE FOR INTEGRATION OF QUESTIONS INTO THE DISCUSSION OF THE RESULTS. .149

APPENDIX M

DETAILED RESULTS OBTAINED FOR QUESTION 11 .151

APPENDIX N

STATISTICAL ANALYSIS. 153 


\section{LIST OF TABLES}

Table 2.1: $\quad$ Research focusing on the emergent literacy of deaf children

Table 2.2: $\quad$ Research focusing on the emergent literacy of hearing children

Table 3.1: $\quad$ Pilot study phase 1

Table 3.2: $\quad$ Pilot study phase 1: Adaptation of the initial version of the questionnaire

Table 3.3: $\quad$ Pilot study phase 2

Table 3.4: $\quad$ Pilot study phase 2: Translation of the questionnaire

Table 3.5: $\quad$ Pilot study phase 3

Table 3.6: Pilot study phase 3: Field-testing of the final versions of the questionnaire

Table 3.7: Background information on respondents who completed the questionnaire

Table 3.8: Background information on deaf children who participated in the research

Table 3.9: A summary of subjects selected from the schools participating in the research

Table 3.10: A Summary of consent letters and questionnaires issued and returned

Table 3.11: Presentation of children who met the subject selection criteria

Table 3.12: Questionnaire outline

Table 4.1: Deaf children's favourite reading material according to their hearing parents

Table 4.2: $\quad$ Deaf children's communication during story reading activities

Table 4.3: $\quad$ Sibling's participation in reading and writing activities with the deaf child 


\section{LIST OF FIGURES}

Figure 3.1: A schematic presentation of the three phases of the pilot study

Figure 4.1: $\quad$ Outline for presentation and discussion of results

Figure 4.2: $\quad$ Deaf children's favourite activities as reported by their parents

Figure 4.3: Deaf children's enjoyment of reading

Figure 4.4: Deaf children's interest in reading and writing activities

Figure 4.5: Family's interest in reading activities

Figure 4.6: The frequency of the family's reading and writing activities

Figure 4.7: Deaf children's book ownership

Figure 4.8: Reading material parents usually read to their children

Figure 4.9: Frequency of engagement in reading and writing activities by the deaf child

Figure 4.10: The nature of reading activities and the frequency of engagement in these activities

Figure 4.11: The deaf child's behaviour during story reading activities

Figure 4.12: Nature of parents' participation during story reading activities with their deaf children

Figure 4.13: Initiator of reading and writing activities within the home

Figure 4.14: Parental ratings of most important aspects of their deaf children's development

Figure 4.15: Parent's allocation of responsibility in teaching deaf children to read and write

Figure 4.16: Respondents' experiences of school support 


\section{LIST OF APPENDICES}

Appendix A: Development and description of questionnaire content with theoretical justification

Appendix B: Results of pilot study phase one adjustments to the question format, question formulation and response format

Appendix C: Results of pilot study phase two adjustments to the questionnaire following the translation into Afrikaans

Appendix D: Questionnaire

Appendix E: Vraelys

Appendix F: Covering letter to the questionnaire in English and Afrikaans

Appendix G: Letter of permission to conduct the research: Gauteng Department of Education

Appendix H: Ethical clearance from the University of Pretoria

Appendix I: Consent and information letter to schools and units

Appendix J: Parental consent letters for participation in the research

Appendix K: Questionnaire: categories for open questions

Appendix L: Outline for integration of questions into the discussion of the results

Appendix M: Detailed results obtained for question 11

Appendix N: Statistical analysis 


\section{CHAPTER 1 \\ INTRODUCTION TO THE STUDY}

Deafness is an invisible disability, which has a profound impact on a young child's language and literacy development. For many deaf children, the early years are marked by much confusion amongst the magic of their early development (Sass-Lehrer and Bodner-Johnson, 2003). The importance of early intervention in the language and communication development of young deaf children has been recognised for a long time. The present research will address another aspect of this early development, by focussing on the home-based literacy experiences of severely to profoundly deaf preschool children.

\subsection{Statement of the problem}

The significance of literacy in modern society cannot be underestimated. Current South African statistics indicate that about two thirds of the deaf adult population are functionally illiterate and unemployed (McAllister, 2004). This corresponds with wordwide concern about the fact that deaf people generally underachieve in the acquisition of their literacy skills, with far reaching implications for their personal development (Watson, 1999; Webster, 2000; Loeterman, Paul and Donahue, 2002; Swanwick, 2002; Paul, 2003).

The low literacy levels of deaf individuals are alarming if one considers that, as society becomes more information based, there will be an increasing need for higher levels of literacy amongst the deaf to facilitate successful participation and interaction in the hearing world. The ability to read and write competently increases the likelihood of academic success, provides more career opportunities and ultimately leads to greater personal fulfilment and improved quality of life (Koppenhaver, Evans and Yoder, 1991; Blume, 2003). Given this situation, there is an urgent need to investigate the factors that may contribute to improving the literacy skills of deaf individuals.

Loeterman et al (2002) highlight a number of factors that influence deaf children's development of literacy, such as phonemic awareness, vocabulary, syntax and the use of prior knowledge and metacognitive skills. The role of early literacy exposure as the foundation to later literacy development has now also been identified in the literature as a 
factor that contributes to the development of literacy in deaf children. Research has shown that the foundations for literacy development are established well before a child commences with formal schooling (Light and Kent-Walsh, 2003). Recent literature (Schirmer and Williams, 2003; Swanwick and Watson, 2005) highlights the need for a paradigm shift in the understanding of the nature and importance of deaf children's early literacy development.

Many authors (Erting and Pfau, 1997; Heineman-Gosschalk and Webster, 2003; Swanwick and Watson, 2005), highlight the need for research into deaf children's early literacy learning. The limitation of previous literacy research for the deaf is that it is mostly based on hearing models of literacy development without the recognition of the unique linguistic situation of the deaf child (Swanwick, 2002). Furthermore, research has traditionally focused mainly on the linguistic development of deaf children. The general belief has been that establishing a primary language base in either speech or sign precedes, or is a prerequisite for, written language development (Heineman-Gosschalk and Webster, 2003).

According to Swanwick and Watson (2005), the study of deaf children's early literacy experiences raises fundamental questions about access to language and early interaction in their home environments. Koppenhaver, Coleman, Kalman and Yoder (1991) conclude that successful development of literacy skills seems to be related to supportive literacy experiences within the home and school context. Difficulties in developing reading and writing skills may reflect the limited access which young deaf children have to supportive literacy experiences within their home and school environments. Heineman-Gosschalk and Webster (2003) state that there are generalised findings in the literature about parents' difficulties in providing early literacy experiences to their young deaf children but very little on exactly what these difficulties are.

It is against this background that the present research will describe the home-based literacy experiences of severely to profoundly deaf pre-schoolers as provided by their hearing parents. The nature of early literacy exposure in the home environment will be investigated with reference to four literacy contexts identified. This research may highlight the need to include literacy development in the early intervention with young deaf children. 


\subsection{Definition of terms}

The following terminology is used in this report and defined as follows:

\subsubsection{Emergent literacy}

Teale and Sulzby (1986) describe emergent literacy as young children's knowledge concerning the forms and functions of print. It includes the reading and writing behaviours that precede and develop into later conventional literacy skills. Emergent literacy therefore includes a range of experiences, activities, understandings and misunderstandings as the child learns to derive meaning from print (reads) and learns to create print (writes) prior to formal literacy instruction.

\subsubsection{Home-based literacy experiences}

These refer to the early literacy activities such as storybook reading where children are introduced to books by their parents and other literate adults within the home environment. It includes the critical roles played by these adults in creating supportive language and literacy environments at home (Light, Binger and Kelford-Smith, 1994; Van Kleeck, 1990).

\subsubsection{Deafness}

Deafness, as a loss of peripheral hearing in one or both ears, can be described with reference to two different paradigms. Within a clinical framework, deafness can be viewed as a disability, which need to be prevented or cured. In contrast, a cultural paradigm “depathologises” deafness (Clark, 2002, p2). The distinction between viewing deafness clinically and thus using a lower case "d" and a cultural perspective of Deafness and thus using an upper case " $\mathrm{D}$ ” is beyond the scope of the present research. The lowercase "d" will be adhered to throughout the report to prevent confusion. This is however not a reflection of the author's views on deafness.

\subsubsection{Oralism}

Oralism refers to the use of an oral language as mode of communication with the deaf child. This means that the parents adopt a spoken language as the preferred language. This language is used for communication and literacy mediation at home and at school. 


\subsubsection{Bilingualism}

Bilingualism refers to the situation where both Sign Language and a spoken language are used in the home. The aim is for the deaf children to develop Sign Language as their first language. Spoken and written languages develop alongside Sign Language and are taught at school as the second language (Swanwick and Watson, 2005).

\subsubsection{Parents}

In this research, reference will be made to the "parents of deaf children". The term "parents" is used to refer to the biological parents of the deaf children. The term “parents” will also be used to refer to the primary caregivers (adoptive parents and foster parents) in whose care the children are due to absence of their biological parents.

\subsection{Outline of the chapters}

\subsubsection{Chapter one: introduction}

This chapter presents a motivation for the present research. Terms used in the title of the research are defined. This chapter also provides an outline of the chapters in the research report.

\subsubsection{Chapter two: overview of the literature}

This chapter provides a critical discussion of the literature as it relates to the research topic. Key issues relating to the emergent literacy skills of deaf children are addressed with reference to four literacy contexts identified.

\subsubsection{Chapter three: methodology}

The aims of the research are presented and the research design is described. This chapter also gives a detailed overview of the questionnaire design and development. The threephase pilot study used in the questionnaire development is described. Participants in the research are described and the procedures for data collection are presented. Lastly, the statistical procedures implemented in data analysis are described.

\subsubsection{Chapter four: results and discussion}

This chapter provides a visual presentation and description of the results obtained from the questionnaire with reference to the four literacy contexts identified. This chapter also 
presents an integrated and critical discussion of the results with reference to current literature.

\subsubsection{Chapter five: conclusion and recommendations}

This chapter presents the conclusion to the research with reference to the four literacy contexts. The limitations of this research are discussed and implications for future research are presented. Chapter five is followed by a reference list of all authors quoted and the appendices referred to in the text.

\subsection{Abbreviations}

The following abbreviations have been used in the text:

SL: refers to Sign Language

AAC: refers to Augmentative and Alternative Communication

ND: refers to non-disabled

\subsection{Summary}

Chapter one presented a motivation for the present research by highlighting the low levels of literacy in the deaf population and the need for research into the early literacy development of young deaf children. The chapter concluded with a definition of key terms and an outline of the chapters to follow in this research report. 


\section{CHAPTER 2}

\section{REVIEW OF THE LITERATURE}

\subsection{Introduction}

Historically, research into the acquisition of reading and writing skills in deaf children has consistently revealed low levels of literacy (Paul, 1998; Marschark and Lukomski, 2002; Swanwick and Watson, 2005). These consistent low levels of literacy are a concern, as Watson (1999, p97) expresses that "the development of reading and writing and achievement of literacy skills in the deaf present a gloomy picture”. Given the fact that some deaf children do not even attain functional levels of literacy, it is necessary to reflect on the factors that may contribute to the development of literacy skills in this population group.

The literature extensively debates the reasons for the reading difficulties of deaf children and how these difficulties are best addressed. It is, however, difficult to identify one “cause” for these low levels of literacy. The variables involved in reading acquisition of deaf children are complex and difficult, if not impossible to change (Marschark, 2001). The focus of this research project is on emergent literacy skills as one variable to consider in exploring the low reading levels of deaf children.

Teale and Sulzby (1986, p. xix) adopted the term 'emergent literacy' to signal a break from the traditional focus on reading readiness where the acquisition of specific skills are implied and to emphasise the fact that "children are in the process of becoming literate, as the term emergent indicates”. According to Yaden, Rowe and MacGillivray (2000, p426), the term emergent literacy implies a "wide theoretical stance about literacy learning (developmental and constructivist) and age (birth to 5-6 years of age) and a focus on informal learning in holistic activities at home, pre-school or kindergarten”. The present research uses the term emergent literacy, and acknowledges that, as pointed out by Yaden et al (2000), there is controversy amongst researchers in their perspectives on and approaches to the study of early literacy learning. Emergent literacy concerns the children's knowledge concerning the forms and functions of print and the relationship between oral and written language (Teale and Sulzby, 1986). It also includes early skills relating to book orientation, early print awareness and knowledge of print, prior to the acquisition of formal literacy skills. 
This chapter will present emergent literacy as the cornerstone of literacy development and highlight the relevance of this for deaf children. Four literacy contexts will be identified to describe the home-based literacy experiences of severely to profoundly deaf pre-schoolers. These contexts will be discussed with reference to the aims of the research.

\subsection{Emergent literacy as the cornerstone of literacy development}

According to Teale (2003, p41), "the initial part of the $21^{\text {st }}$ century has emerged as a period offering unprecedented attention to emergent literacy”. The focus has been on exposure to both reading and writing activities in the home and pre-school environments and the acquisition of these skills as part of early child development and intervention. Whitehurst and Lonigan (1998) emphasise that emergent literacy consists of skills, knowledge and attitudes that are developmental precursors to reading and writing and the environments that support these developments. The foundations for reading development can be seen in the early shared book experiences between parents and children and the foundations for writing development are in the child's early scribbling and drawings.

During early interactions with print and writing material in supportive home environments, children acquire skills that can be viewed as components of emergent literacy. Whitehurst and Lonigan (1998) describe these skills in terms of the child acquiring knowledge on the functions, uses and significance of text, which form the foundation for later conventional literacy learning. In the context of emergent literacy, the child needs exposure to literacy related activities in the home environment that involve both reading and writing.

Early reading and writing experiences are thus considered as equal components of a complex process involving both production and reception of written language. Koppenhaver, Coleman, Kalman and Yoder (1991) view reading and writing as cognitive activities embedded in social and linguistic contexts and as such, are greatly influenced by these contexts. The development of reading and writing skills is an interactive process that involves communication, listening, speaking, reading and writing related to everyday life, irrespective of the mode of communication used for the deaf child. These components are not only interrelated, but they develop simultaneously and 
interactively along a developmental continuum with its origins early in the life of the child (Teale and Sulzby, 1986; Whitehurst and Lonigan, 1998; Watson, 1999).

Emergent literacy acquisition is an ongoing process with emphasis on growth and development in the home and pre-school setting and not on the acquisition of specific skills, which must be taught. Children must be encouraged to participate in meaningful reading and writing activities with adults and other children in their social and cultural environment, to provide a foundation for the acquisition of later formal literacy skills. The origin of literacy is in the social contexts of the home and the community and the child's early experiences with print will determine whether later formal literacy learning builds on existing understandings and skills or whether the child will be confronted with an entirely new set of learning challenges (Koppenhaver et al, 1991a; Schirmer and Williams, 2003).

Emergent literacy skills therefore, form the foundation for and are inextricably part of a child's literacy development. Whitehurst and Lonigan (1998) propose that a description of emergent literacy must refer to the characteristics and abilities of the child as well as to the emergent literacy environment which refers to the adults in the child's environment and the nature of the environment within which the child develops. Ewoldt (1985) also highlights the need for appropriate environmental conditions for the nurturing of reading and writing skills. This shows that literacy learning cannot be separated from the context within which these skills develop and mature.

It is thus proposed that emergent literacy consists of component skills the deaf child needs to acquire as a foundation to the development of more conventional literacy learning. These skills can only be acquired in a literacy-favourable context that supports and encourages early literacy activities. According to Williams (2004), deaf children's emergent reading reflects the same developmental sequence as hearing children and deaf children are likely to benefit from early literacy-based experiences in the same way as hearing children do.

It is suggested that with the emphasis on early language acquisition for deaf children, the role of emergent literacy in the development of these children is currently being neglected (Swanwick and Watson, 2005). The aim of this research is to describe the 
home-based literacy experiences of young deaf children to determine the extent to which the children in this study are exposed to early literacy activities. The theoretical discussion, aims and methodology of the present research are based on and developed from relevant research on the emergent literacy of deaf children and hearing children (typically developing children and children using AAC).

\subsection{Overview of research studies on emergent literacy relevant to the present research}

To ensure development and progress in the field of emergent literacy and deafness, continued research should be guided by methodological observations and results of research that has already been done. Neuman and Dickinson (2002) indicate that the study of early literacy is maturing. This is evident in emerging theoretical stances and development of instructional approaches, which are subjected to serious empirical scrutiny. It is suggested that emergent literacy as pertaining to deaf children has not yet reached such maturity due to the emphasis on language acquisition in deaf children and the views that language competence is a prerequisite for literacy development.

Yaden et al (2000) state that the advantage of knowledge of the emergent literacy research pool is that a researcher can take ownership of his/her own perspective and also recognise, understand and hopefully appreciate other different viewpoints. A methodological crossroad in emergent literacy research has been identified by Yaden et al (2000, p446) and these authors emphasise the need for "a broader array of research participants so that a wider range of social, political, economic and cultural understanding of literacy is presented in the literature”. The need for continued research into the emergent literacy skills of deaf children as a specific group is thus highlighted.

An overview of the research, which has contributed to the theoretical background, and methodology of the present research are presented in Table 2.1 and Table 2.2 respectively. These studies focus on emergent literacy development in the home environment as well as the pre-school setting and implement different methodologies to document and observe the emergent literacy acquisition in young children. 
Table 2.1, on the next two pages, presents an overview of research conducted on deaf children. From the studies presented, the following conclusions have been drawn which form a theoretical foundation for the present research. These conclusions are:

1. The early work by Andrews and Taylor (1987) highlights the value of printoriented home environments and the need for determining the nature of these environments as part of the emergent literacy development of young deaf children.

2. Deaf children have the same natural ability to develop literacy skills as hearing children do, given favourable and supportive contexts at home and at school (Ewoldt, 1985; Gioia, 2001)

3. Deaf children's delayed language acquisition does not prevent them from developing emergent literacy skills (Williams, 1994; Williams and McLean, 1997).

4. Deaf children can use literacy as an interactional tool. The roots of such interaction are in the early home-based literacy experiences of young children and such interactions can be shared between parents and children irrespective of the mode of communication used (Rottenberg and Searfoss, 1992).

5. Literacy-rich environments at home and at school and collaboration between these two contexts foster and support emergent literacy development in young deaf children (Akamatsu and Andrews, 1993; Gillespie and Twardosz, 1997; Heineman-Gosschalk and Webster, 2003).

Table 2.1 is followed by another summary of research studies, which shaped the present research arguments and methodology. These studies are presented in Table 2.2 and involve emergent literacy research conducted on hearing children. 


\section{Table 2.1: Research focusing on the emergent literacy of deaf children}

\begin{tabular}{|c|c|c|c|}
\hline Study & Research Aims & Methodology & Results of the research \\
\hline Ewoldt (1985) & $\begin{array}{l}\text { To document the literacy development of } 10 \text { deaf } \\
\text { children aged 3-5 years over a three-year period in a } \\
\text { pre-school setting. }\end{array}$ & $\begin{array}{l}\text { Naturalistic measures involving live } \\
\text { observations, videotaping, parent interviews } \\
\text { and writing samples. }\end{array}$ & $\begin{array}{l}\text { The patterns and strategies observed in hearing children were present and functioning in deaf children. } \\
\text { This research shows that literacy development in deaf children is a naturally emerging process that can } \\
\text { parallel development in hearing children, given supportive environments. }\end{array}$ \\
\hline $\begin{array}{l}\text { Andrews and } \\
\text { Taylor (1987) }\end{array}$ & $\begin{array}{l}\text { To document the reading practice of a hard-of-hearing } \\
\text { mother with her three and a half-year old hearing- } \\
\text { impaired son. The aim was to determine the nature of } \\
\text { the print environment the child is exposed to as well } \\
\text { as the strategies the mother used when reading to her } \\
\text { child. }\end{array}$ & $\begin{array}{l}\text { A case-study design comprising a one-hour } \\
\text { interview with the mother and a } 45 \text {-minute } \\
\text { video recording of a reading session of the } \\
\text { mother and her child. }\end{array}$ & $\begin{array}{l}\text { The results show that this child is exposed to a varied print-oriented environment where ample reading } \\
\text { and writing materials are available to him. He regularly observes his parents reading and writing for } \\
\text { recreation. He interacts with print on a daily basis and family members explain concepts to him. In the } \\
\text { shared reading activities it is clear that this mother is able to provide her child with successful } \\
\text { scaffolding for his early literacy development. The strategies used by the mother are discussed in } \\
\text { detail. The educational significance of providing secure and successful book interactions with deaf } \\
\text { children are highlighted. }\end{array}$ \\
\hline $\begin{array}{l}\text { Rottenberg and } \\
\text { Searfoss (1992) }\end{array}$ & $\begin{array}{l}\text { To examine the patterns of literacy learning common } \\
\text { across } 7 \text { deaf children in a pre-school setting }\end{array}$ & $\begin{array}{l}\text { Qualitative methods involving observation of } \\
\text { the children, drawing and writing samples } \\
\text { and interviews with teachers and parents over } \\
\text { a } 9 \text { month period }\end{array}$ & $\begin{array}{l}\text { The deaf children in this study used literacy for entry into the hearing world. They used literacy as a } \\
\text { tool for communication and interaction and as a means of making sense of the world around them. } \\
\text { These results show that deaf children view literacy events as significant. The children in the study } \\
\text { made great efforts to engage in literacy-related activities. }\end{array}$ \\
\hline $\begin{array}{l}\text { Akamatsu and } \\
\text { Andrews (1993) }\end{array}$ & $\begin{array}{l}\text { To provide a description of one deaf child's literacy } \\
\text { development from age two to five as it is shaped by } \\
\text { adult scaffolding. To describe the structure of } \\
\text { dialogue and the types of literacy activities parents } \\
\text { and children engage in. This study involved a deaf } \\
\text { child and deaf parents }\end{array}$ & $\begin{array}{l}\text { Longitudinal study with qualitative analysis } \\
\text { of data with reference to the literacy } \\
\text { behaviour of the child, the strategies used by } \\
\text { adults to engage the child in literacy, } \\
\text { strategies used by the child to engage and } \\
\text { seek adult support and the dialogue involved. }\end{array}$ & $\begin{array}{l}\text { These results show the importance of talking about text and the engagement in literacy-related } \\
\text { activities that include both reading and writing. The need for visually rich environments for deaf } \\
\text { children is emphasised. }\end{array}$ \\
\hline Williams (1994) & $\begin{array}{l}\text { To determine the nature of three deaf children's } \\
\text { language and literacy worlds and to describe the } \\
\text { knowledge and understanding the children have about } \\
\text { written language upon informal assessment. }\end{array}$ & $\begin{array}{l}\text { Naturalistic case study methodology with a } \\
\text { qualitative and interpretive approach to data } \\
\text { collection and analysis. }\end{array}$ & $\begin{array}{l}\text { Results highlight the need to acknowledge the complexities involved in deaf children's early language } \\
\text { development and the difficulty parents are faced with in selecting an appropriate mode of } \\
\text { communication for their children. The deaf children's experiences with verbal language were different } \\
\text { from one another's and from hearing children's experiences with spoken language. Williams (1994, } \\
\text { p.145) state that "the children's delayed language acquisition did not prevent them from experiencing, } \\
\text { participating and using written language in their homes in ways that hearing children do". }\end{array}$ \\
\hline
\end{tabular}




\begin{tabular}{|c|c|c|c|}
\hline $\begin{array}{l}\text { Gillespie and } \\
\text { Twardosz (1997) }\end{array}$ & $\begin{array}{l}\text { To document group storybook readings with attention } \\
\text { to adult reading styles and children's responses. To } \\
\text { assess the effects of storybook reading on deaf } \\
\text { children's literacy development with reference to } \\
\text { reading or pretending to read a familiar book. }\end{array}$ & $\begin{array}{l}\text { Before-after experimental group/control } \\
\text { group design. } 18 \text { children, aged } 4-11 \text { years, } \\
\text { from } 4 \text { cottages at a residential school for the } \\
\text { deaf, were assigned to either the experimental } \\
\text { or control group. }\end{array}$ & $\begin{array}{l}\text { When readers employed interactive and/or expressive reading styles, children were significantly more } \\
\text { engaged than when reading was unexpressive. The results show that in literacy rich environments, deaf } \\
\text { children can become more independent in their reading and develop a greater interest in books. } \\
\text { Independence was identified as an important aspect of emergent reading development. }\end{array}$ \\
\hline $\begin{array}{l}\text { Williams and } \\
\text { McLean (1997) }\end{array}$ & $\begin{array}{l}\text { To examine deaf children's response to picture book } \\
\text { reading in a pre-school setting and to compare } \\
\text { responses to those of hearing children as documented } \\
\text { in research literature. }\end{array}$ & $\begin{array}{l}\text { Qualitative methodology with systematic } \\
\text { observation in three classrooms over a 6- } \\
\text { month period. Data analysis involved the } \\
\text { transcription of video recordings. }\end{array}$ & $\begin{array}{l}\text { Despite severe language delays, the deaf children's responses to storybook reading events were very } \\
\text { similar to hearing children's responses. The deaf children learnt a great deal about what reading was } \\
\text { about through the storybook reading events. This study acknowledges the value of storybook reading } \\
\text { and highlights the importance of the deaf child's responses to picture books. }\end{array}$ \\
\hline Gioi & $\begin{array}{l}\text { To document the ways in which the deaf children } \\
\text { interacted with and around storybooks in a pre-school } \\
\text { setting. }\end{array}$ & $\begin{array}{l}\text { Multiple case study with three profoundly } \\
\text { deaf pre-schoolers aged } 3 \text { and } 4 \text { years over a } \\
\text { 12-month period. An ethnographic } \\
\text { methodology was implemented to document } \\
\text { the language and literacy experiences of the } \\
\text { deaf children. }\end{array}$ & $\begin{array}{l}\text { These results highlight the parallels between deaf and hearing children regarding their participation and } \\
\text { benefit from literacy endeavours. The results also show that storybook sharing provides a powerful } \\
\text { language and literacy milieu and allows children "to weave important literacy knowledge with } \\
\text { language learning" (Gioia 2001, p421). This research indicates that through interactive storybook } \\
\text { reading, deaf children are able to participate in lap reading traditions enjoyed by all children. Results } \\
\text { also show that the families had well-established literacy practices in the home but not satisfactory } \\
\text { shared reading rituals with their deaf children. The results importantly show that support from the } \\
\text { school in helping parents read to their children, increased the frequency of storybook reading at home. }\end{array}$ \\
\hline $\begin{array}{l}\text { Heineman- } \\
\text { Gosschalk and } \\
\text { Webster (2003) }\end{array}$ & $\begin{array}{l}\text { To determine the involvement of parents in the } \\
\text { reading development of their deaf children and to } \\
\text { describe parental experiences of reading with their } \\
\text { deaf children. The relationship between parents and } \\
\text { teachers in establishing a literacy environment is } \\
\text { emphasised. }\end{array}$ & $\begin{array}{l}\text { Survey methodology where two different } \\
\text { fixed item questionnaires were used. One was } \\
\text { sent to } 100 \text { parents of deaf children, the other } \\
\text { was sent to } 80 \text { teachers working at hearing } \\
\text { impaired services and schools for the deaf }\end{array}$ & $\begin{array}{l}\text { Results of this research highlight the need for collaboration between parents and teachers in } \\
\text { establishing a literacy environment for deaf children. The results further show that parents enjoy } \\
\text { reading to their deaf children but they experience obstacles in the reading process. The parents also } \\
\text { show uncertainty regarding the most effective ways in which to enable their deaf children to become } \\
\text { literate. }\end{array}$ \\
\hline
\end{tabular}


The studies presented in Table 2.2 reflect research conducted on hearing children, which includes typically developing children and children who use AAC. Research on emergent literacy skills of deaf children must not be isolated. This means that valuable guidelines can be obtained from early literacy acquisition of hearing children. The studies in Table 2.2 contributed to the theoretical background of the present research as follows:

1. Based on the work by Light and Kelford-Smith (1993) four literacy-related contexts were identified which served as a foundation for the present research. These four contexts guided the theoretical discussion and the development of the methodology.

2. The work by Dodici, Draper and Peterson (2003) shows that parent-child interactions are strongly related to emergent literacy learning. Justice et al (2005) also highlight the value of exposure to storybook text and the impact it can have on vocabulary learning. A description of the home-based literacy experiences of deaf children may give some information on the parent-child interactions and the extent to which deaf children in this study are exposed to literate adult role-models in their home environments. The need for emphasis on the emergent literacy skills of deaf children becomes clear, as research has indicated the benefits early parent-child interaction around text for language acquisition and later literacy development.

3. The value of storybook reading between parent and child as a potential vocabulary-building activity has been extensively described (Justice, Meier and Walpole, 2005). This served as a further motivation to determine the nature of home-based literacy experiences and storybook reading activities between parents and deaf pre-schoolers.

4. Lenhart and Roskos (2003) highlight the role of sibling interaction in literacy development. The questionnaire developed for the present research included this aspect of literacy development in the home environment.

5. The questionnaire developed by Boudreau (2005) also guided the formulation of questions. It was included in the development of the questionnaire used in the present research. Boudreau's (2005) research highlights that parent questionnaires can be used successfully in obtaining information regarding young children’s literacy development. 
Table 2.2: Research focusing on the emergent literacy of hearing children (typically developing children and children using AAC)

\begin{tabular}{|c|c|c|c|}
\hline Study & Research Aims & Methodology & Results of the research \\
\hline Light and Kelford-Smith (1993) & $\begin{array}{l}\text { To compare the home literacy } \\
\text { experiences of physically disabled pre- } \\
\text { schoolers who use AAC systems to the } \\
\text { experiences of their non-disabled (ND) } \\
\text { peers. }\end{array}$ & $\begin{array}{l}\text { A survey methodology was implemented where } 15 \\
\text { parents from each group of children were requested to } \\
\text { complete a questionnaire developed according to four } \\
\text { contexts identified as relevant to home literacy } \\
\text { experiences. }\end{array}$ & $\begin{array}{l}\text { The results of this survey show that the physical and functional contexts, } \\
\text { language and cultural contexts of the home literacy experiences of children } \\
\text { who use AAC differ significantly from the experiences of their ND peers. } \\
\text { The need for further research into the school literacy environments of these } \\
\text { children is stressed. }\end{array}$ \\
\hline Dodici, Draper and Peterson (2003) & $\begin{array}{l}\text { To examine the relationship between } \\
\text { parent-child interactions and early } \\
\text { literacy skills. The central thought is that } \\
\text { children learn via daily interactions with } \\
\text { their parents and other significant adults } \\
\text { during play and teaching. }\end{array}$ & $\begin{array}{l}\text { A longitudinal study where } 27 \text { families living in low- } \\
\text { income households were examined. Parent-child } \\
\text { interactions in "simulated" daily experiences were } \\
\text { videotaped at age intervals } 14,24 \text { and } 36 \text { months. }\end{array}$ & $\begin{array}{l}\text { The results show that observed parent-child interactions are strongly related } \\
\text { to emergent literacy learning in the areas of receptive vocabulary, symbolic } \\
\text { representation and phonemic analysis. This research provides the theoretical } \\
\text { grounding for empirical examination of how specific characteristics of } \\
\text { parent-child interactions influence the development of early literacy skills. } \\
\text { The researchers highlight the limitations of utilising only a parent report on } \\
\text { home-based literacy experiences. This is in contrast to the findings of } \\
\text { Boudreau (2005) where the value of parent reports is emphasised. }\end{array}$ \\
\hline Lenhart and Roskos (2003) & $\begin{array}{l}\text { To document the literacy learning and } \\
\text { interaction between two siblings by } \\
\text { adopting a Vygotskian perspective. }\end{array}$ & $\begin{array}{l}\text { A longitudinal case study by a parent-researcher. The } \\
\text { literacy events between siblings in the flow of everyday } \\
\text { life are observed and documented and then discussed } \\
\text { with reference to the literature. }\end{array}$ & $\begin{array}{l}\text { The results show how the older sibling imparts literacy knowledge to the } \\
\text { younger child. This case study also shows how the older sibling } \\
\text { demonstrates literacy skills to the younger child. The older sibling shapes } \\
\text { the younger child's emergent attitudes towards print and books. }\end{array}$ \\
\hline Boudreau (2005) & $\begin{array}{l}\text { To evaluate the use of a parent } \\
\text { questionnaire in the assessment of } \\
\text { language and emergent literacy skills in } \\
\text { young pre-school children with language } \\
\text { impairments (LI) and to compare the } \\
\text { results with their typically developing } \\
\text { peers. }\end{array}$ & $\begin{array}{l}\text { A survey methodology was implemented where parents } \\
\text { were requested to complete a questionnaire that was } \\
\text { developed for the purposes of the research. }\end{array}$ & $\begin{array}{l}\text { The results show a strong relationship between examiner-administered } \\
\text { assessments of early literacy and reports received from the parents of LI } \\
\text { children only. A comparison of the two groups find differences in time spent } \\
\text { watching television, age parents began reading to their children and number } \\
\text { of books owned by the children. This research supports the use of a parent } \\
\text { report as a tool in the assessment of emergent and early literacy knowledge } \\
\text { for children with LI. }\end{array}$ \\
\hline Justice, Meier and Walpole (2005) & $\begin{array}{l}\text { To examine the ability of children from } \\
\text { low socio-economic status groups, to } \\
\text { learn new words from storybook texts } \\
\text { and to study individual differences in } \\
\text { terms of response to treatment. }\end{array}$ & $\begin{array}{l}\text { A pre-test/post-test comparison group research design } \\
\text { was implemented. } 57 \text { children were randomly assigned to } \\
\text { an experimental and comparison group. }\end{array}$ & $\begin{array}{l}\text { A modest overall word-learning gain is observed in both groups of children } \\
\text { although the experimental group shows significantly greater gains in } \\
\text { elaborate words. Children with low vocabulary make the greatest gains in } \\
\text { elaborate words. }\end{array}$ \\
\hline
\end{tabular}


The research overview presented in Table 2.1 and Table 2.2 therefore serves as a background to the theoretical discussion and as a foundation to the questionnaire development and methodology presented in Chapter three. The research overview also serves as a guide for the presentation and discussion of the results in Chapter four.

\subsection{Factors to consider in the emergent literacy development of deaf children}

Based on the overview of research results presented in Table 2.1, it is suggested that a discussion of the acquisition of early literacy skills in deaf children should consider three factors:

1. The first factor relates to Paul's (1998) view that there are many reading theories on emergent and conventional literacy learning which offer diverse and conflicting interpretations of literacy learning in deaf children. This relates to whether deaf children can in fact acquire literacy in the same way as hearing children.

2. The second factor relates to the reality that deaf children do not share an accessible first language with their hearing parents (Marschark, 2001). The language difficulties of deaf children and mode of communication adopted by parents of deaf children cannot be ignored when considering the literacy acquisition of a deaf child.

3. The third factor relates to Teale's (2003) view that learning to read and write is a complex process, which must be understood with consideration of the context and culture within which it occurs. These three factors impact on an understanding of the role of emergent literacy in the reading and writing development of deaf children.

\subsubsection{The role of theories in emergent literacy of deaf children}

There are conflicting views in the literature on whether reading theories based on hearing children can be applied to the understanding of reading development and reading difficulties of deaf children. Various authors point out that hearing models cannot be blindly applied to the deaf population. According to Paul (1998), theorising on the literacy development of deaf individuals must be based on an acknowledgment of the relationship between deaf culture and literacy. This calls for an understanding of how deaf children approach and deal with print-related information and the manner in which deaf people use literacy. Theories on the emergent literacy development of young deaf children must therefore take into consideration that deaf children may construct meaning in ways different from hearing children.

Paul (2003) highlights the ongoing debate on whether the reading development of deaf children is similar to that of hearing children and thus justifying the use of mainstream literacy models for 
understanding and improving literacy skills. Marschark and Lukomski (2002, p71) say that “the egalitarian pronouncements of equity and flexibility of the young deaf learner may be wrong and following them blindly may be an even greater disservice to deaf children than treating them as though they are different from hearing children”. The question that arises is: which theoretical perspectives can best be implemented to understand the reading development of young deaf children and thus lead to the best possible intervention strategies?

In an attempt to answer this question, reference can be made to Webster (2000, p139-140), who identifies two main branches in literacy research in the field of deafness. One branch highlights "models constructed around the unique learning characteristics of deaf individuals (literacy different) which includes strategies for bypassing areas of literacy development that are inherently problematic, such as the grapheme-phoneme correspondence”. The other branch focuses on "similarities between the literacy development in hearing and deaf children (literacy same)" where the reading and writing processes in deaf children are understood and approached through resources and activities, which have been shown to be effective for hearing children.

It is proposed that both these perspectives may be usefully applied to understanding the literacy development of deaf children. Regarding “literacy different”, Williams (1994) points out that the language and literacy worlds of young deaf children are probably more diverse than those of their hearing peers as they move in and out of contexts where different language modalities are used by people of different levels of communicative competence. Marschark and Lukomski (2002) also highlight the fact that due to their unique language and communication situation, deaf children's early experiences may be different from hearing children's experiences. An understanding of the nature of these differences may foster the development of strategies and materials that may be more effective for the deaf.

Regarding "literacy same", the implication is that reading can be introduced "via personal, meaningful and purposeful exposure to print-rich environments, including story reading so that these literacy events are closely integrated with the children's language development” (Webster, 2000, p140). These ideas have already been applied to early intervention with deaf children in family and school contexts (Williams, 1994; Williams and McLean, 1997). According to Watson (1999), an acceptance of similarities between the experiences of learning to read and write between deaf and hearing children implies that deaf children must meet the same criteria as hearing children to have a chance of achieving adequate levels of literacy. This means that deaf children require a 
solid language base, the ability to use language for literacy purposes, a workable word knowledge, knowledge of books and stories as well as effective word attack skills for reading and writing (Watson, 1999).

Paul (1998) highlights the value of meta-analysis of various different theories and perspectives to synthesise information for the best possible understanding of the complexities of acquisition of literacy skills in deaf children. Therefore, using the understanding of the differences between hearing and deaf children's literacy development and the criteria for literacy development of hearing children, the challenge then is to apply these insights and criteria within a given language approach to facilitate and support the early literacy development of young deaf children.

\subsubsection{The role of language in the emergent literacy of deaf children}

Since the 1990s, it has been acknowledged that reading is a language-based skill (Wood and Hood, 2004) and currently the interrelationship between the development of language and literacy is receiving more attention in the literature. It is suggested that the acquisition of literacy skills, like language development, proceeds along a developmental continuum so that literacy learning can also be viewed as a continuous, evolving process, which starts from birth. According to Williams (2004), research findings show that spoken language, reading and writing develop concomitantly in literate environments and with mutual reinforcement in development.

Various authors highlight the complexity of the deaf child's early linguistic and literacy experiences. Erting and Pfau (1997) point out that most deaf children are born into a unique linguistic situation as they are born to hearing parents who have difficulties in communicating with their children, irrespective of the mode of communication used at home. Marschark (2001) also emphasises the challenges involved in effective early communication between parents and deaf children, the limited exposure to competent language models and the social and experiential hurdles with which the deaf child is confronted. The complexity of the deaf child's linguistic situation is further highlighted by Heinemann-Gosschalk and Webster (2003, p22) when they state that the "language and literacy worlds of young deaf children are probably more diverse than those of hearing children as they move in and out of contexts where different language modalities are used by people of varying degrees of linguistic competence”.

The consequence of this complex language and communication situation is that deaf children do not develop a strong linguistic base with which to express themselves and make sense of the world, 
resulting in them being cognitively, experientially and linguistically behind their hearing peers (Erting and Pfau, 1997). These issues may also impact on the deaf child's ability to benefit from, and participate in, home-based literacy experiences as provided by their hearing parents.

Until recently, there has been little research on deaf children's early literacy learning, partly because of a general belief that a primary communication mode (spoken or Sign Language) is a precursor to the development of literacy skills and thus takes precedence over the development of literacy skills (Webster and Heinemann-Gosschalk, 2000; Sagstetter, 2004). Research by Williams (1994) and Williams and McLean (1997) do, however, indicate that delayed language acquisition of deaf children does not prevent them from participating in early literacy events. It can thus be concluded that deaf children have the same potential to develop language and literacy skills as any other typically developing children. Marschark and Lukomski (2002) however, point out that deaf children may have experiences that are different from hearing children and as such, may develop different patterns of cognitive organisation, which may influence learning and literacy in particular.

The perspectives on early language and literacy development of young deaf children must acknowledge that both language and literacy develop concurrently "within the child" and is dependent on developmentally supportive and nurturing environments “outside the child”. Webster (2000, p136) states that educators are beginning to accept that "language acquisition and literacy learning can occur in parallel and reinforce on another in development, irrespective of the mode of communication”. According to Williams (2004), numerous research studies have demonstrated that the social interaction surrounding early literacy activities is a key factor in supporting the literacy development of young children.

The focus is therefore slowly shifting from viewing the acquisition of reading and writing skills as dependent on a pre-requisite language base, to how children learn to derive meaning from text in literacy-favourable contexts, irrespective of the mode of communication they use. Furthermore, there is evidence in the literature that it is now accepted that the language and literacy development of young deaf children must be understood with reference to the context in which it occurs.

\subsubsection{The role of context in the emergent literacy of deaf children}

As is evident from the preceding discussion, becoming literate is a complex process that involves more than the development of cognitive operations. Gaustad and Paul (1998, p185) say that reading "represents an evolving interaction / transaction between the text and the reader" which cannot be separated from the reader's individuality and interpretation of life experiences. The process of 
learning to acquire meaning from text is embedded in the social and cultural context within which the child develops. Research has shown that the life experiences of typically deaf children when compared to hearing children are restricted, not necessarily due to the deafness, but as a result of the reaction of adults to the presence of the deafness and the fact that adults may underestimate the value of contact with text (Paul, 1998). The acquisition of emergent literacy can thus not be separated from the context of the deaf child's development and the role of significant adults in this context. Teale (2003, p27) further highlights the importance of context and states, "Context is an integral part of thinking rather than merely a backdrop that influences thinking”. Such a perspective has significant theoretical implications for the roles of socio-cultural and linguistic factors in the process of becoming literate.

According to Webster and Heinemann-Gosschalk (2000), a socio-cultural perspective on literacy challenges the assumption that literacy should be taught as a system of rules and draws attention to the role of adults and adult strategies used in interaction with the deaf child. This approach highlights the quality of the child's interactive encounters, shared most often in the early stages with adults around text. Van Kleeck (1990) points out that the child acquires literacy capabilities on two levels, i.e. the psychological level that implies the skill and capabilities of the child, and the social level that refers to the tutorial and support practices provided by parents. The challenge is then to ensure that parents of young deaf children are able to foster the development of a broad general knowledge and an understanding of books and story structure prior to formal schooling (Watson, 1999). This is the essence of emergent literacy, which has its roots in the early meaningful literacy-based (involving reading and writing) interactions between deaf children, their parents and siblings. Whitehurst and Lonigan (1998, p855) refer to this as “a home literacy environment” which fosters the development of emergent literacy.

The fundamental issue in beginning literacy in deaf children is that the child must be exposed to a wide range of meaningful real-world experiences and be exposed to literacy-related activities in the home environment. Parents need to assist their deaf children in creating meaning through active participation in the world around them. This emphasis on meaning-making thus shifts the focus to the literacy environment and specifically to literacy-related interactions between parents and deaf children. These interactions, constructed around text will shape deaf children's early reading and writing experiences (Gaustad and Paul, 1998; Webster and Heinemann-Gosschalk, 2000). 
Literacy development can thus be viewed as a socially constructed phenomenon, which means that the deaf child's cognitive and linguistic processes for acquiring literacy skills as well as the support systems provided by the family, social and educational community for learning these skills must be considered (Light and Kelford-Smith, 1993). Therefore, a description of home-based literacy experiences must be based on an understanding of the contexts in which it occurs. Light and Kelford-Smith (1993) suggest that literacy events are embedded within multiple contexts, which affect both the child and the literacy event. Based on the work of these authors, four contexts surrounding the literacy experiences of young deaf children that are important in describing their home-based literacy experiences have been identified. These four contexts are as follows:

\subsubsection{The physical and functional context}

This context refers to the elements of the actual physical environment surrounding the child and the structure and function of daily activities. The functional aspect refers to the interpersonal interaction within the family, which consists of literacy experiences with a child by parents, siblings and other individuals in the home, and the physical aspects include the literacy materials available in the home (Morrow, 1993). It is the physical and social resources of the home that give rise to literacy activity and determine its nature. This includes literacy-related interactions between all members of the family. The home environment is also powerful in shaping sibling literacy interactions. Older siblings can share their knowledge of literacy in ways that are sensitive, instructive and enjoyable. Lenhart and Roskos (2003, p.90) emphasise the role of siblings in literacy-related interactions and state, "siblings can create zones of proximal development, scaffold instruction and demonstrate their roles as effective teachers for their younger siblings”.

This physical and functional context, furthermore, refers to the "culture of literacy" in the home and the family’s literacy routines. Heinemann-Gosschalk and Webster (2003, p.21) state, "The extent to which parents display and encourage an interest in reading and writing has been described as the single most important factor associated with children's educational development”. The parents' interest and participation in their own literacy-related activities serve as positive role models for the deaf child. Morrow (1993) points out that children require literacy models and literacy partners for them to observe reading and writing behaviours, and to see what a literate person does before, and after, they read and write.

In literacy-immersed environments children, therefore, observe demonstrations of how print functions and is produced. Lenhart and Roskos (2003) state that the literate environment of the 
home fosters interest in, and curiosity about, written language and supports children's efforts to become readers and writers both within and outside of the home. Truax et al (2004, p309) state that as "children become engaged personally in the literacy process, they begin to assume responsibility for selecting books and activities to meet social and personal purposes”.

The aim of including the physical and functional context is to determine how literacy practice operates in the homes of young deaf children as this may influence the children's attitudes and knowledge about literacy (Gillen and Hall, 2003).

\subsubsection{The language context}

This context refers to the interaction between adult and child during literacy activities and the patterns of language use within these interactions. Family-specific variations in parenting behaviours around text have been linked directly to the development of literacy skills in young deaf children (Heinemann-Gosschalk and Webster, 2003).

In the preceding discussion, it has been suggested that literacy learning proceeds in parallel with language development. During the period of emergent literacy development, children acquire important lexical and syntactic knowledge that supports their later literacy (Light and Kent-Walsh, 2003). The language input that deaf children receive may, however, be qualitatively and quantatively different from that of typically developing peers. Various authors highlight the possible difficulties parents may experience within this context. Williams (1994, p.127) states “ it takes time to develop a mutual system of communication; consequently, many profoundly deaf children are unlikely to have extensive, meaningful interactions with their hearing parents during the early school years”. Furthermore, parents of deaf children may experience difficulties during literacy-based interaction because print-related activities cannot be mapped onto an already established language (Swanwick and Watson, 2005). This may, in turn, have an impact on the child's ability to derive meaning from literacy-based interactions. Morrow (1993, p2) states that the conditions that promote first language learning are the same conditions that promote total literacy development and, created in a social context surrounding the child, "involve immersion, approximation, and opportunity for practice, feedback and modelling”.

When the child is immersed in literacy in the home environment, the child has the opportunity to explore a range of print communication and can engage in activities of interest. Truax, Foo and Whitesell (2004) highlight the need for parents' meaningful responses to the child's approximations 
during literacy activities, as well as responsive interaction to assist the child in constructing meaning from print. Within the language context, Van Kleeck (1990) stresses the role of parents in scaffolding the child's contributions during literacy events. This means that parents must be able to structure and constrain the linguistic and non-linguistic context to facilitate the child's success during literacy-related activities.

The aim in including the language context is to determine the nature of communication between parents and children, and the difficulty parents may experience in communicating with their children around text.

\subsubsection{The affective context}

The affective context refers to the parents' values and beliefs about literacy and their expectations of literacy development. It is suggested that the affective aspects relating to early literacy development need more attention because the attitudes and expectations of the parents, regarding their deaf child's literacy development, will impact on the child's attitudes and participation in early literacy related activities. Morrow (1993) states that the emotional and motivational context comprises the relationship among the individuals in the home, especially as reflected in the parents' attitudes towards literacy and their aspirations for their children’s literacy development.

According to Paul (1998), parental expectations of literacy development are reflected in their nonverbal and verbal expressions and this impacts on how they approach and value literacy interactions with their child. Most children between two and five enjoy drawing and writing to some degree, especially if they are showered with positive reinforcement for their efforts. Developing a positive attitude towards their ability to draw and write is the first step towards becoming a reader/writer (Erting and Pfau, 1997). Deaf children therefore need to be part of positive and supportive environments where parents have realistic expectations regarding their children's literacy development. Swanwick and Watson (2005) point out that the creation of such environments is dependent on the parents' own experiences, perceptions and assumptions about deafness.

The aim in including this context is therefore to determine parents' expectations regarding their children's literacy development as this will also impact on the responsibility assumed by the parents in providing positive and supportive home-based literacy experiences to their deaf children. 


\subsubsection{The educational context}

The educational context refers to the collaboration between the parent and the teacher in facilitating literacy experiences for the young child. It also includes the guidance and support parents receive from teachers in this regard. Research by Heinemann-Gosschalk and Webster (2003) indicates that most parents do not receive advice from professionals regarding effective literacy interaction with their deaf children.

Deaf children need instructional activities that are adapted to their interests, experiences as well as their rate and style of learning (Truax et al 2004). This necessitates collaboration between the child's parents and the school. This home school-based collaboration and communication is, according to Morrow (1993), also associated with better progress in literacy development, and highlights the need for a multidimensional approach to beginning literacy. Heineman-Gosschalk and Webster (2003, p.23) state, "Parent involvement is not about what parents can do for teachers, rather about what schools can do for them”. The teacher plays an important role as a supporter and facilitator of literacy-related activities in the home environment.

The aim in including the educational context as relevant to home-based literacy experiences is to determine the nature of support parents receive from professionals in terms of providing effective literacy support to their deaf children. Furthermore, some insight will be gained into the nature of home-school collaboration in providing meaningful literacy experiences to young deaf children.

Against the background of the three factors presented as relevant to the emergent literacy development of young deaf children, it is suggested that the home-based literacy experiences of these children can be described with reference to four literacy-related contexts. The aim of the present research is to develop a questionnaire based on these four literacy contexts to obtain information on the home-based literacy experiences of young deaf children and their hearing parents. In this way insight may be gained into the role and nature of literacy in the homes of young deaf children and the way in which individual families make their communication meaningful and successful in early reading and writing activities. The research questions and aims of the research are formulated with reference to the four identified literacy contexts. These are presented in the following chapter on the research methodology. 


\subsection{Summary}

This chapter proposed that emergent literacy could be considered as one variable in the low levels of literacy skills in deaf children. The role of emergent literacy as the foundation for literacy development of the young deaf child was described. An overview of research on the emergent literacy of deaf and hearing children is presented as a theoretical background to this research. Three factors relevant to the acquisition of early literacy skills in deaf children were identified and discussed with reference to the literature. Lastly, four contexts, relevant to the description of homebased literacy experiences of deaf children were identified and discussed with reference to the literature. These four contexts form the foundation for the research questions presented in the next chapter. 


\section{CHAPTER 3}

\section{RESEARCH METHODOLOGY}

\subsection{Introduction}

This chapter describes the research methodology that was implemented to describe the home-based literacy experiences of deaf pre-school children. Firstly, the aims of this research are presented and substantiated by the main research question and sub-questions. This is followed by a discussion of the research design and procedures involved in the development of the questionnaire. The aims, results and recommendations of the pilot study are then presented. The criteria for subject selection are discussed and visually presented in tables. Lastly, the procedures for data collection and data analysis, as implemented in the main study, are described.

\subsection{Research aims}

The aim of this research is to provide a description of the home-based literacy experiences of severely to profoundly deaf pre-schoolers and their hearing parents with reference to four contexts, i.e. the physical and functional context, the language context, the affective context and the educational context. These contexts relate to the sub-aims of the research. In order to reach the aims of the research, the following research questions are posed.

\subsection{Research questions}

The main research question is: "What is the nature of the home-based literacy experiences of severely to profoundly deaf pre-schoolers provided by their hearing parents?” With reference to the four literacy contexts identified, the sub questions are as follows:

- What is the nature of the physical and functional context of literacy events for severely to profoundly deaf pre-schoolers?

- With reference to the language context, what is the nature of the parent's communication and the deaf child's communication during literacy-related activities?

- With reference to the affective context, what are the parents' priorities and expectations regarding literacy development for their severely to profoundly deaf pre-school children?

- With reference to the educational context, what is the nature of the support and guidance parents receive from teachers in providing home-based literacy experiences to their severly to profoundly deaf pre-school children? 


\subsection{Research design}

A survey mode of inquiry was implemented and data was collected through a self-administered questionnaire that was hand-delivered to schools for the deaf and pre-school units for language and hearing-impaired children in Gauteng and Kwa-Zulu Natal. A consequence of hand-delivered questionnaires is that smaller geographical areas can be covered (Fouché, 1998). In this instance, specific schools and units within the geographical areas, which were accessible to the researcher, were included in the survey.

\subsection{Research process}

The research process followed a linear course, which involved developing a suitable questionnaire according to the aims of the research. The questionnaire was pilot tested to adapt and refine the questions, to translate it from English to Afrikaans and to test and finalise the measuring instrument in both languages.

Prior to conducting the fieldwork, permission to conduct the research was obtained from the Gauteng Department of Education and the University of Pretoria's Ethics Committee. As the Department of Education in Kwa-Zulu Natal follows a different protocol, consent to conduct the research was necessary from the principal of the school only. Once consent was finalised, schools and pre-school units were contacted and invited to participate in the research.

Once the fieldwork was finalised, raw data was captured, computerised and statistically analysed. This was followed by the interpretation of the results with reference to theory and research aims.

\subsection{Questionnaire development}

A questionnaire was designed and developed to answer the research questions. The questionnaire design was based on two studies: firstly, the research by Light and Kelford-Smith (1993), which compared the home-based literacy experiences of children who use AAC and their ND peers and secondly, the research by Heinemann-Gosschalk and Webster (2003), which considered literacy and the role of parents with reference to the effective partnerships between families and schools. Based on these two studies, theoretical constructs with reference to four literacy contexts were identified and questions were formulated accordingly. Appendix A contains a detailed breakdown of the constructs relating to each question as well as the theoretical justification for questions asked. 
In the questionnaire design, a variety of question formats and response options were utilised. The following question types were included in the questionnaire:

- Open-ended questions: requesting an answer to be written in an open space.

- Closed questions: providing the opportunity of selecting one or more response choices from a number provided. This is advantageous when response options are relatively well known as it provides clarity to the respondents regarding the meaning of the question (Fouché, 1998). The category, “other”, was included to ensure that unique information will not be missed. The majority of questions included in the questionnaire are closed questions as Delport (2002, p.179) highlights that "the degree, frequency and comprehensiveness of a phenomenon can be ascertained quite meaningfully by means of closed questions”. This question format is also most suitable for statistical processing by computer.

- Dichotomous questions with follow-up questions: providing two response possibilities. Further questions followed, to explore the yes/ no option, which was provided.

- Multiple-choice questions: providing three or more response options with the option of "not applicable”. These questions were used to obtain information, which can be divided into hard and fast categories (Fouché, 1998).

- Likert-type scaled questions: providing the opportunity to assign values to given experiences by placing them in order of importance from lowest to highest. The formats of these questions are "questions or statements followed by a scale of potential responses (McMillan and Schumacher, 2001, p262). These questions provide data of a more subjective nature, e.g. attitudes and opinions (Fouché, 1998).

- Matrix-type question: providing the opportunity to answer a variety of interrelated questions in one space.

The different question formats were utilised, according to the information needed to describe the home-based literacy experiences in the four identified contexts. Question formats and response requirements were coordinated to ensure that the questionnaire is as user-friendly as possible. Furthermore, questions and response modes were selected with reference to coding requirements for data analysis. Delport (2002) highlights the need for decisions regarding methods and facilities of data analysis during the questionnaire design as data processing and consequent analysis may be compromised if the questionnaire is not constructed in a specific manner. 
Once the questionnaire was developed, it was pilot tested in three phases (see Figure 3.1). Strydom (1998, p182) emphasises that the purpose of the pilot study is "to improve the success and effectiveness of the investigation, by making sure that the measuring instrument is reliable”.

\subsection{Pilot study}

A pilot study was conducted to address issues of reliability and validity of the developed questionnaire as a measuring instrument and to translate it into Afrikaans. The pilot study allows for adjustments and refinement of the questionnaire with reference to the aims of the research. In this way, attention is given to question formulation, question format and response modes required. Through the pilot study it can thus be determined whether the questions asked and coding procedure implemented, captures and represents the information needed for the targeted theoretical constructs.

For the purposes of the present research, a three-phase pilot study was conducted. Specific aims were set for each phase in an attempt to address the reliability and validity of the questionnaire as a measuring instrument. The aims of the three phases of the pilot study were as follows:

- Phase 1: To finalise the English Questionnaire according to the aims of the research and to ensure clarity in question formation and consistency in response requirements.

- Phase 2: To translate the English questionnaire into Afrikaans and to ensure equivalence in translation.

- Phase 3: To ensure that both versions of the questionnaire are user-friendly. In this phase final editing of the questionnaire was conducted for use in the fieldwork.

Figure 3.1 provides an overview of the stages of the pilot study. This is followed by a description of each of the phases. 


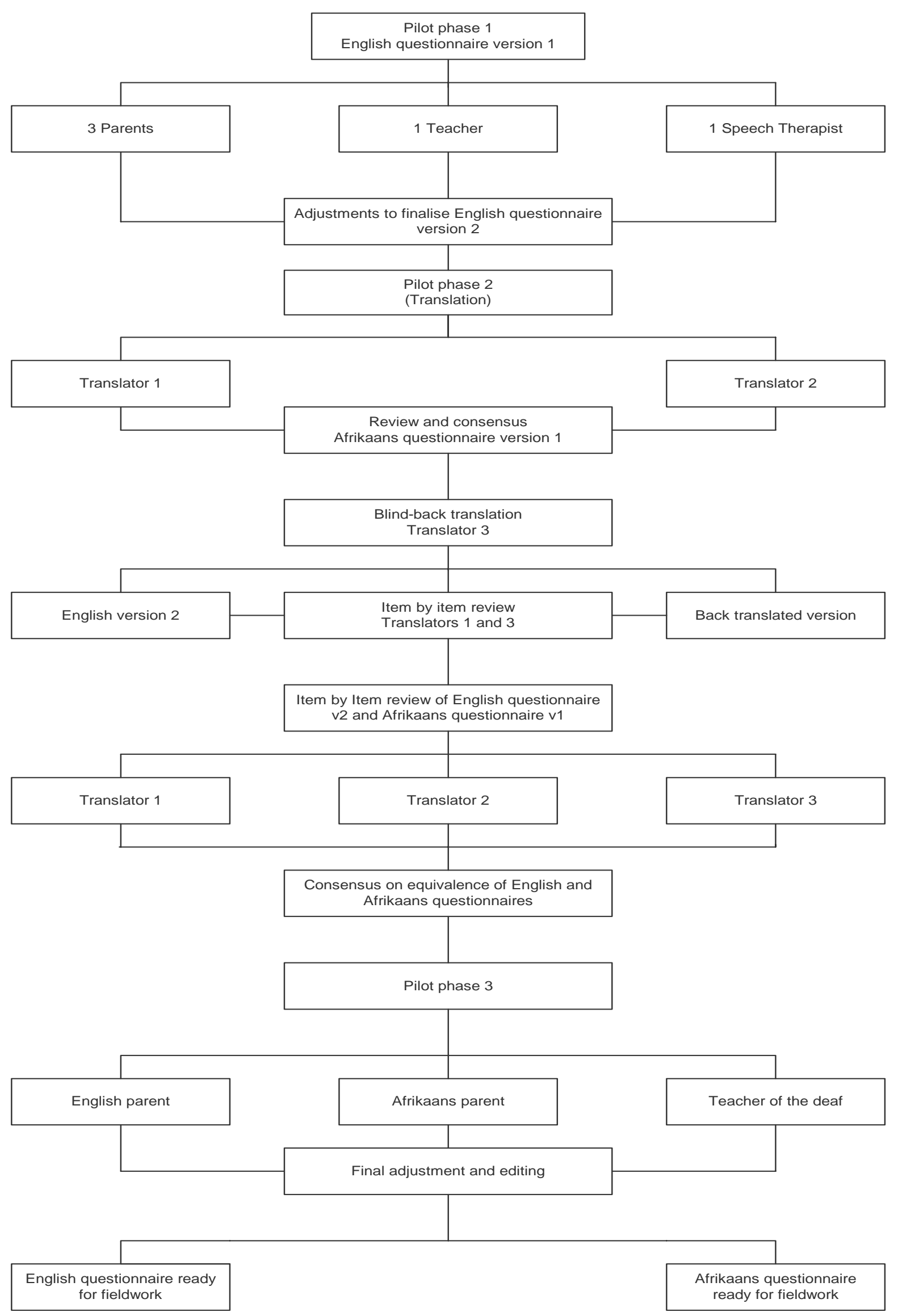

Figure 3.1: A schematic presentation of the three phases of the pilot study

Adapted from Haupt (2001) 


\subsubsection{Pilot study phase 1}

The first phase of the pilot study, in terms of aims, procedures, results and actions taken, are presented in Table 3.1.

Table 3.1: Pilot study phase 1

\begin{tabular}{|c|c|}
\hline Aims & $\begin{array}{l}\text { To adapt and refine the questionnaire according to the aims of the research and to ensure ease of } \\
\text { response to questions. }\end{array}$ \\
\hline Procedures & $\begin{array}{l}\text { The initial draft of the questionnaire was presented to three parents of deaf children, a teacher and a } \\
\text { speech therapist. } \\
\text { The following points were considered: } \\
\text { - Relevance of questions in the different sections } \\
\text { - Whether questions were clear in intent and well understood } \\
\text { - } \quad \text { Adether instructions were clear in intent and understood } \\
\text { - Time taken to complete the questionnaire. }\end{array}$ \\
\hline Results & $\begin{array}{l}\text { A summary of the results is presented in Table } 3.3 \text { which shows that the adjustments needed to the } \\
\text { questionnaire involved: } \\
\text { - question formulation } \\
\text { - response format to questions } \\
\text { A detailed breakdown of these changes can be viewed in Appendix B. }\end{array}$ \\
\hline $\begin{array}{l}\text { Actions } \\
\text { Taken }\end{array}$ & $\begin{array}{l}\text { - The initial draft of the questionnaire was revised and adjusted accordingly. } \\
\text { - The adjusted version of the English questionnaire was then ready for Phase two of the pilot } \\
\text { study. }\end{array}$ \\
\hline
\end{tabular}

Table 3.2 presents the changes, which were made to the questionnaire, following phase one of the pilot study. 


\section{Table 3.2: Pilot study phase one: Adaptation of the initial version of the questionnaire}

\section{(View this table in conjunction with Appendix B)}

\begin{tabular}{|c|c|c|}
\hline Adjustment & $\begin{array}{l}\text { Questions as per sections in } \\
\text { PILOT Questionnaire }\end{array}$ & Nature of adjustment \\
\hline \multirow{7}{*}{$\begin{array}{l}\text { Adjustment in question format } \\
\text { and question formulation }\end{array}$} & A: Q 3, 4 \& 5 & $\begin{array}{l}\text { Following the responses received on education and employment, it was necessary to reformulate these questions and to refine the } \\
\text { response options given. }\end{array}$ \\
\hline & B: Q 1, 3 \& 5 & $\begin{array}{l}\text { The multiple-choice categories for the questions on the child's age, communication used at home and age at time of diagnosis } \\
\text { were refined. }\end{array}$ \\
\hline & C: Q 1 & The question on daily activities was difficult to complete and thus omitted. Information needed was absorbed in other questions. \\
\hline & C: Q11 & The question format of this question was refined and more specific instructions for answering the question were provided. \\
\hline & C: Q12 & $\begin{array}{l}\text { This question appeared twice in the questionnaire in different formats. This question was omitted as the information was } \\
\text { obtained in a different question. }\end{array}$ \\
\hline & C: Q 14 & The question on book-related activities was reformulated to remove ambiguity and ensure ease in response. \\
\hline & C: Q $16 \& 19$ & $\begin{array}{l}\text { Following recommendations from professionals, these questions were refined to include more options regarding communication } \\
\text { and behaviour during reading activities. }\end{array}$ \\
\hline \multirow{6}{*}{ Adjustment in response format } & A: Q 7 \& 8 & Response format was changed to closed question response mode to provide more specific information \\
\hline & B: Q 2 & Information relating to siblings, gender, age and hearing status was tabulated in a matrix format to ensure ease in responding \\
\hline & B: Q 4 \& 5 & $\begin{array}{l}\text { Refinement of the response options to give parents more choice regarding the communication with their children at home, as } \\
\text { well as with reference to the assistive listening devices used by their deaf children. }\end{array}$ \\
\hline & C: Q3 \& 8 & $\begin{array}{l}\text { A four-point scale relating to the family and the deaf child's interest in reading and writing activities was presented for all these } \\
\text { questions to ensure minimal variation in response format. }\end{array}$ \\
\hline & C: Q4, 7, 21 \& 24 & $\begin{array}{l}\text { A five-point time scale was used to gauge the time spent on reading and drawing activities by the family as well as by the deaf } \\
\text { child. The same five-point scale was used as response format for all these questions to ensure consistency. }\end{array}$ \\
\hline & General & $\begin{array}{l}\text { To ensure clarity in requirements for answering questions, instructions were standardised and provided throughout the } \\
\text { questionnaire. }\end{array}$ \\
\hline Adjustment in coding & $\begin{array}{l}\text { Concerns all the questions in } \\
\text { the questionnaire. }\end{array}$ & $\begin{array}{l}\text { The initial basic coding system was changed to code all response options. The coding process also allows for the coding of } \\
\text { categories identified following the analysis of responses to open-ended questions. This is to facilitate accuracy in data capturing. }\end{array}$ \\
\hline
\end{tabular}




\subsubsection{Pilot study phase 2}

The aims, procedures, results and actions taken following phase two of the pilot study, are presented in Table 3.3.

Table 3.3: Pilot study phase 2

\begin{tabular}{|c|c|}
\hline Aims & $\begin{array}{l}\text { To translate the questionnaire into Afrikaans and to ensure that the questions and response options in the } \\
\text { English and Afrikaans versions were essentially equivalent in meaning. Alant (2005) points out that during } \\
\text { translation from one language to another, equivalence in the messages produced must be proven, as it } \\
\text { cannot be assumed. }\end{array}$ \\
\hline lures & $\begin{array}{l}\text { To ensure equivalence in translation of the present questionnaire, the guidelines for translation by Bracken } \\
\text { and Barone (1991) were followed. This meant that an independent bilingual individual conducted a blind } \\
\text { back-translation of the Afrikaans questionnaire into English. Figure } 3.1 \text { shows the process of translation. } \\
\text { The translation of the questionnaire proceeded as follows: } \\
\text { The English questionnaire was provisionally translated into Afrikaans by the researcher (translator 1), who } \\
\text { is fully bilingual. } \\
\text { An Educational Psychologist (translator 2), who is an Afrikaans mother-tongue speaker, also translated the } \\
\text { English questionnaire into Afrikaans. } \\
\text { Translators } 1 \text { and } 2 \text { then compared the two Afrikaans translations. Adjustments were made and a } \\
\text { provisional Afrikaans version of the questionnaire was accepted. } \\
\text { The provisional Afrikaans translation was presented to a Speech Therapist (translator 3), who is fluent in } \\
\text { English and Afrikaans. She performed a blind back-translation of this questionnaire into English. } \\
\text { Translators } 1,2 \text { and } 3 \text { compared the blind back English translation with the original English questionnaire. } \\
\text { This was done to determine whether there were questions and response options in the Afrikaans version that } \\
\text { differed in meaning from the English version of the questionnaire. } \\
\text { The final versions of the English and Afrikaans questionnaires were adjusted to ensure equality in } \\
\text { translation. Both versions were edited for spelling and grammatical errors. }\end{array}$ \\
\hline Res & $\begin{array}{l}\text { A summary of the adjustments needed in the English and Afrikaans questionnaires following the translation } \\
\text { is presented in Table } 3.5 \text { and the changes are detailed in Appendix C. Table } 3.5 \text { shows: } \\
\text { Discrepancies in translation of words and phrases of five questions and differences in the wording of the } \\
\text { eight questions. } \\
\text { A need for clarity in response requirements in both the English and Afrikaans questionnaires involving five } \\
\text { questions. } \\
\text { Section A: five out of the eight questions were accurately translated. In this section, three questions needed } \\
\text { adjustments. } \\
\text { Section B, three out of the five questions were correctly translated. } \\
\text { Section C, nineteen out of the thirty questions were accurately translated and needed no modification. }\end{array}$ \\
\hline & $\begin{array}{l}\text { Once the translation of the questionnaire was finalised, both copies were edited for spelling and } \\
\text { grammatical errors. } \\
\text { The statistical coding of both questionnaires was revised and updated. } \\
\text { The questionnaires were then ready for the next phase of pilot testing. }\end{array}$ \\
\hline
\end{tabular}


A summary of the adjustments needed to both the English and Afrikaans versions of the questionnaires following the process of translation is presented in Table 3.4. The details of these changes are presented in Appendix C.

Table 3.4: Pilot study phase two: Translation of the questionnaire

(View this table in conjunction with Appendix C)

\begin{tabular}{|l|c|l|}
\hline \multicolumn{1}{|c|}{$\begin{array}{c}\text { Reasons for adjustments to the } \\
\text { questionnaires }\end{array}$} & $\begin{array}{c}\text { Total (n) of } \\
\text { questions }\end{array}$ & \multicolumn{1}{|c|}{ Questions (Q) concerned } \\
\hline $\begin{array}{l}\text { Discrepancies in translation of words or } \\
\text { phrases }\end{array}$ & $\mathrm{n}=5$ & $\begin{array}{l}\text { Section A: Q5 and 6 } \\
\text { Section B: Q3 } \\
\text { Section C: Q3, 13 and 28 }\end{array}$ \\
\hline Discrepancies in wording of the questions & $\mathrm{n}=8$ & $\begin{array}{l}\text { Section A: Q8 } \\
\text { Section B: Q2 } \\
\text { Section C: Q4, 9, 11, 12, 20 and } 26\end{array}$ \\
\hline $\begin{array}{l}\text { Clarity in response requirements in both } \\
\text { the questionnaires }\end{array}$ & $\mathrm{n}=5$ & $\begin{array}{l}\text { Section B: Q3 } \\
\text { Section C: Q5, 9, 11 and 21 }\end{array}$ \\
\hline
\end{tabular}

\subsubsection{Pilot study phase 3}

The aim, procedures, results and actions for the third phase of the pilot study are presented in Table 3.5. Table 3.6 follows this, where the details of the results obtained during this phase of the pilot study are shown.

Table 3.5: Pilot study phase 3

\begin{tabular}{|l|l|}
\hline Aims & $\begin{array}{l}\text { To field test the finalised versions of the Afrikaans and English questionnaires and to determine whether } \\
\text { the questionnaires were user-friendly and ready for the main research. }\end{array}$ \\
\hline Procedures & $\begin{array}{l}\text { Questionnaires were presented to one English parent, one Afrikaans parent and one pre-school teacher of } \\
\text { deaf children. }\end{array}$ \\
\hline Results & $\begin{array}{l}\text { A summary of the comments obtained from this phase is presented in Table 3.7 which shows: } \\
\text { Revision of two questions was needed in both versions of the questionnaire to ensure that these questions } \\
\text { Results also highlighted the fact that it took about an hour to complete the questionnaire. This may become } \\
\text { a limiting factor in motivating parents to participate in the research. } \\
\text { Parents may provide information to satisfy the researcher, rather than presenting their own unique } \\
\text { experiences. This Hawthorne effect (McMillan and Schumacher, 2001, p192) may be "a threat to external } \\
\text { validity" of the research. This is one limitation of using a questionnaire as a measuring instrument. }\end{array}$ \\
\hline Actions & $\begin{array}{l}\text { The concern regarding the Hawthorne effect was addressed in the covering letters to the questionnaires. } \\
\text { Parents were assured that their unique experiences are of value and that there are no correct or incorrect } \\
\text { answers to the questions. }\end{array}$ \\
\hline
\end{tabular}


Table 3.6 gives a list of the adjustments needed to the questionnaire following the final stage of the pilot study.

Table 3.6: Pilot study phase three: Field-testing of the final versions of the questionnaire

\begin{tabular}{|c|c|c|c|}
\hline & $\begin{array}{l}\text { Number of } \\
\text { Comments }\end{array}$ & Nature of comments & Adjustments to the questionnaire \\
\hline Parent A & $n=3$ & 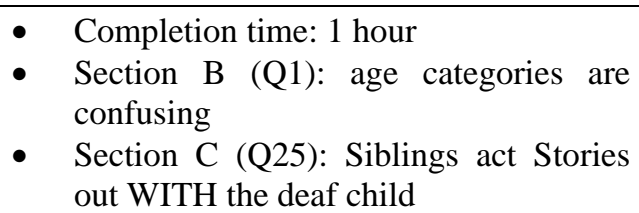 & $\begin{array}{l}\text { Section B: Q1 revised with minor } \\
\text { adjustments to ensure greater clarity. } \\
\text { Section C: Q } 25 \text { addition of the question } \\
\text { formulation in both versions of the } \\
\text { questionnaire. }\end{array}$ \\
\hline Parent E & $n=3$ & $\begin{array}{l}\text { - } \quad \text { Completion time: } 1 \frac{1 / 2 \text { hours }}{\text { - }} \text { The difficulties in reading and signing } \\
\text { to a deaf child were highlighted } \\
\text { - The need for regular story reading was } \\
\text { emphasised }\end{array}$ & $\begin{array}{l}\text { No adjustments needed following these } \\
\text { comments. Comments highlight the need } \\
\text { for this research. }\end{array}$ \\
\hline Teacher & $n=2$ & $\begin{array}{l}\text { - Appropriateness of questionnaire for } \\
\text { rural people was questioned } \\
\text { - Questioned possibility of impact of the } \\
\text { Hawthorne effect }\end{array}$ & $\begin{array}{l}\text { The questionnaire is not intended for the } \\
\text { rural population. } \\
\text { Covering letter to the questionnaire } \\
\text { emphasises the value of individual } \\
\text { experiences. }\end{array}$ \\
\hline
\end{tabular}

During the three phases of the pilot study the questionnaires were adjusted and refined to meet the aims of the research and to address issues of validity and reliability in research. According to Delport (2002, p.167), it is important to determine "the degree to which an instrument successfully measures a theoretical construct”. In the present questionnaire design each question has been related to a theoretical construct. The aim of the pilot study was therefore to ensure that the questionnaire measures the target constructs, that an adequate sample of items representing the constructs was included in the questionnaire and that respondents can provide information to clearly formulated questions. In this way the validity of the questionnaire as a measuring instrument was addressed.

\subsection{The main research study}

For the purposes of the present research, a sample of children was selected according to stipulated criteria as presented in 3.8.2 of this section. The parents of these children were invited to participate in the research. In this context, reference is made to children who met the research criteria, implying that only children, whose parents also met the stipulated research criteria, were included in the research. 


\subsubsection{Selection of participants}

Three government schools for the deaf and two private pre-school units for language and hearingimpaired children in Gauteng as well as one government school for the deaf in Kwa-Zulu Natal were approached for participation in the research. One school outside of the Gauteng geographical area was invited to participate to include more children using Sign Language into the study. Within the selected schools, all the children who met the selection criteria were invited to participate.

\subsubsection{Criteria for subject selection}

The speech therapists at the schools provided the information needed to select subjects to participate in the research. Subjects were selected according to the following criteria stipulated for parents and children.

\subsubsection{Parents}

- Parents participating in the research must have normal hearing. Deaf parents were excluded, as they do not experience the same language barriers as hearing parents when interacting with their deaf children through sign language (Erting and Pfau, 1997).

- Parents participating in the research must have proficiency in English or Afrikaans at a level that they are able to complete the questionnaires. This is to ensure that parents can independently complete the questionnaire.

- Parents must be willing to participate in the research by providing the information requested on the questionnaire. Parents must sign a consent letter indicating their willingness to participate.

\subsubsection{Children}

- Children included in the research must have congenitally or pre-lingual sensori-neural deafness. Post lingual acquired deafness was excluded from the research as it impacts differently on the language and literacy development of the deaf children.

- Deafness must be within severe $(80-100 \mathrm{~dB})$ to profound ranges $(100-120 \mathrm{~dB})$ as these ranges have the most significant impact on language and communication development. This diagnostic information was obtained from the children's records presented by the speech therapists at the various schools.

- The ages of the children must be between 2 and 7 years as this is the age where they are in early intervention programmes or at pre-schools and not yet exposed to formal literacy 
instruction. Children up to the age of 7 years are included as in many deaf children are diagnosed late and thus in pre-school at an older age.

- The children must be in a pre-school setting, which caters for deaf children. The mode of communication could be either oral, sign or total communication. A distinction in modes of communication is beyond the scope of the present research.

- The children must be either day scholars or weekly boarders. Children in long-term boarding were excluded, as they do not have the opportunities for regular literacy experiences in the home environment. It was decided to include weekly boarders (at school from Monday to Friday), as most of the children at the government schools are boarders.

- The children must have normal cognitive functioning as assessed by their teachers. Cognitive delays will add different demands to the home and educational setting, which is beyond the scope of the present study. Levels of cognitive functioning were ascertained through viewing children's records and discussion with the speech therapists at the various schools.

Based on the above-mentioned criteria, a research sample was selected. The subjects who participated in this research can be described according to the information that was obtained in sections $\mathrm{A}$ and $\mathrm{B}$ of the questionnaire.

\subsubsection{Description of subjects}

The descriptive information presented by parents who completed the questionnaires is presented in Table 3.7 and Table 3.8 respectively.

\subsubsection{Description of parents}

From the results presented in Table 3.7, it can be seen that the children's mothers (66\%), mostly completed the questionnaires. In one instance both parents completed the form and in other cases is was completed by other male or female relatives in whose care the child is due to absence of the biological parents. Most respondents were married and within the age of 31 - 40 years. Respondent's level of education ranged from less than 10 years at school (10\%) to 2 or more years post-school qualifications (56\%). Most of the respondents were employed on a fulltime basis (65\%) and indicated that their spouses were also full time employed (68\%). Given the majority of post school qualifications and levels of employment it can be concluded that these parents fall within the mid to higher socio-economic levels. Morrow (1993) highlights that literacy-rich environments, not 
parents' education, occupation or socio-economic level correlate most highly with children's early literacy ability.

Regarding the languages spoken at home, it can be seen that English is the home language of most families (52\%), followed by a variety of African languages (27\%) and Afrikaans (21\%). From the information presented about other languages used at home it is clear that many deaf children are exposed to more that one language in the home situation. 28\% of respondents indicated that Sign Language is another language used at home, while 31\% said that no languages other than the home language are used. English (34\%) and Afrikaans (13\%) were amongst other languages, cited as additional languages used at home. 
Table 3.7: Background information on respondents who completed the questionnaire

\begin{tabular}{|c|c|}
\hline Parameter addressed. & Results obtained from 29 respondents. \\
\hline $\begin{array}{l}\text { Respondent's relationship to the } \\
\text { deaf child }\end{array}$ & $\begin{array}{l}\text { Mother } 19 \text { (66\%) } \\
\text { Father } \mathbf{5}(\mathbf{1 8 \% )} \\
\text { Both parents } \mathbf{1} \text { (3\%) } \\
\text { Female relative (grandmother/aunt) } \mathbf{3}(\mathbf{1 0 \% )} \\
\text { Male relative (uncle) } \mathbf{1}(\mathbf{3 \% )}\end{array}$ \\
\hline Age of respondent & $\begin{array}{l}20-30 \text { years } 4(\mathbf{1 4 \% )} \\
31-40 \text { years } 18(\mathbf{6 2 \% )}) \\
41-50 \text { years } 6(\mathbf{2 1 \% )} \\
51 \text { and older } 1(\mathbf{3 \% )}\end{array}$ \\
\hline Marital status & $\begin{array}{l}\text { Single } 7 \mathbf{( 2 4 \% )} \\
\text { Married } 22 \text { (76\%) }\end{array}$ \\
\hline Level of education & $\begin{array}{l}\text { Less than } 10 \text { years at school } \mathbf{3}(\mathbf{1 0} \%) \\
\text { 10-12 years at school } \mathbf{1 0}(\mathbf{3 4 \% )} \\
\text { 2-3 years after school } \mathbf{8}(\mathbf{2 8 \% )} \\
4 \text { or more years after school } \mathbf{8}(\mathbf{2 8 \% )}\end{array}$ \\
\hline Respondent's employment status & $\begin{array}{l}\text { Unemployed } 4 \text { (14\%) } \\
\text { Homemaker } 4 \text { (14\%) } \\
\text { Part-time employment } 2 \text { (7\%) } \\
\text { Full-time employment } 19 \text { (65\%) }\end{array}$ \\
\hline $\begin{array}{l}\text { Respondent's spouse: employment } \\
\text { status }\end{array}$ & $\begin{array}{l}\text { Unemployed } 2 \text { (8\%) } \\
\text { Homemaker } 1 \text { (4\%) } \\
\text { Part-time employment } 5 \text { (20\%) } \\
\text { Full-time employment } 17 \text { (68\%) }\end{array}$ \\
\hline Home Language & $\begin{array}{l}\text { Afrikaans } 6(\mathbf{2 1 \% )} \\
\text { English } 15 \mathbf{( 5 2 \% )} \\
\text { Sotho } 2 \mathbf{( 7 \% )} \\
\text { Zulu } 3 \mathbf{( 1 0 \% )} \\
\text { Other African languages (Setswana/Tsonga/Venda) } \mathbf{3}(\mathbf{1 0 \% )}\end{array}$ \\
\hline Other languages used at home & $\begin{array}{l}\text { Afrikaans } 4 \text { (13\%) } \\
\text { English } 10 \text { (34\%) } \\
\text { Sotho } 3 \mathbf{( 1 0 \% )} \\
\text { Sign Language } 8 \text { (28\%) } \\
\text { Other European Languages (Polish) } \mathbf{1}(\mathbf{3 \% )} \\
\text { No other languages used } \mathbf{9}(\mathbf{3 1 \% )}\end{array}$ \\
\hline
\end{tabular}

Respondents also presented information regarding their deaf children. A summary of these results is presented in Table 3.8 .

\subsubsection{Description of children}

From the results obtained in section B of the questionnaire, it can be seen that the ages of the children ranged from 2 years to 6.11 years, which is typically the age of pre-school children. All the 
deaf children had hearing siblings and the ages of the siblings ranged from 1 to 21 years. Most of the children's deafness was diagnosed prior to the age of 2 years, although there were still instances of late diagnosis after 3 years of age. Parents indicated that they use a range of communication modes when communicating with their deaf children, with speech and gesture (35\%) appearing as the most used means of communication. Most of the deaf children used some means of sound amplification with only two children not using hearing aids or cochlear implants.

Table 3.8: Background information on deaf children who participated in the research

\begin{tabular}{|c|c|}
\hline Parameter addressed. & Results obtained from 29 respondents. \\
\hline $\begin{array}{l}\text { Age of the deaf child } \\
\text { Age range: } 2-6.11 \text { years } \\
\text { Mean age: } 4.4 \text { years }\end{array}$ & $\begin{array}{l}2 \text { - } 2.11 \text { years: } 1 \mathbf{( 3 \% )} \\
3 \text { - } 3.11 \text { years: } 8(\mathbf{2 8 \% )} \\
4-4.11 \text { years: } 4(\mathbf{1 4 \% )} \\
5 \text { - } 5.11 \text { years: } \mathbf{1 0}(\mathbf{3 4 \% )} \\
6 \text { - } 6.11 \text { years: } \mathbf{6}(\mathbf{2 1 \% )}\end{array}$ \\
\hline $\begin{array}{l}\text { Siblings of the deaf child } \\
\text { Other siblings: Yes } \mathbf{2 4}(\mathbf{8 3 \% )} \\
\text { No other siblings: } \mathbf{5}(\mathbf{1 7 \% )}\end{array}$ & $\begin{array}{l}\text { Brothers: } 16 \text { (46\%) } \\
\text { Sisters: } 19 \text { (54\%) } \\
\text { All siblings were hearing } \\
\text { Age range of siblings: } 1 \text { - } 21 \text { years }\end{array}$ \\
\hline Child's age at diagnosis of deafness & $\begin{array}{l}0-12 \text { months: } 10 \text { (36\%) } \\
\text { 13 - } 24 \text { months: } 11(\mathbf{3 9 \% )} \\
\text { 25 -36 months: } 3 \mathbf{( 1 1 \% )} \\
\text { After } 3 \text { years: } \mathbf{4}(\mathbf{1 4 \% )}\end{array}$ \\
\hline $\begin{array}{l}\text { Respondent's communication with the deaf } \\
\text { child }\end{array}$ & $\begin{array}{l}\text { Speech only: } 6 \text { (21\%) } \\
\text { Sign only: } 1 \text { (3\%) } \\
\text { Speech and Sign: } \mathbf{5}(\mathbf{1 7 \% )} \\
\text { Speech and gesture: } 10 \text { (35\%) } \\
\text { Speech, Sign and gesture: } 7 \text { (24\%) }\end{array}$ \\
\hline Amplification systems used by the deaf child & $\begin{array}{l}\text { Hearing aids: } 19 \text { children } \\
\text { Cochlear implants: } 11 \text { children } \\
\text { FM Systems: } 4 \text { children } \\
\text { No amplification systems used: } 2 \text { children }\end{array}$ \\
\hline
\end{tabular}

The results from sections A and B of the questionnaire, therefore, present the background for the further interpretation of results obtained in section $\mathrm{C}$ of the questionnaire.

\subsubsection{Research sample}

The research sample consisted of parents of children, from the various participating schools, who met the subject selection criteria as was presented in Table 3.7 and Table 3.8. The percentages of children from the various schools selected for participation in the research are presented in Table 3.9. This table shows that 40 children out of a pre-school population of 87 children met the subject 
selection criteria. $46 \%$ of the total pre-school population at the selected schools were therefore suitable candidates to invite to participate in the research.

Table 3.9: A summary of subjects selected from the schools participating in the research

\begin{tabular}{|l|c|c|c|}
\hline $\begin{array}{c}\text { School for the deaf } \\
\text { or pre-school unit } \\
\text { for deaf/language- } \\
\text { impaired children }\end{array}$ & $\begin{array}{c}\text { Total of deaf } \\
\text { children in the } \\
\text { pre-school } \\
\text { groups }\end{array}$ & $\begin{array}{c}\text { Total deaf } \\
\text { children who met } \\
\text { subject selection } \\
\text { criteria } \\
\text { (Research sample) }\end{array}$ & $\begin{array}{c}\text { Percentage of deaf } \\
\text { children whose } \\
\text { parents participated } \\
\text { in the research }\end{array}$ \\
\hline School A & 6 & 2 & $33 \%$ \\
\hline School B & 29 & 12 & $41 \%$ \\
\hline School C & 2 & 1 & $50 \%$ \\
\hline School D & 6 & 3 & $50 \%$ \\
\hline School E & 15 & 13 & $86 \%$ \\
\hline School F & $\mathbf{8 7}$ & 9 & $\mathbf{4 6 \%}$ \\
\hline Totals & & $\mathbf{4 0}$ & \\
\hline
\end{tabular}

Following the selection of the initial sample of 40 deaf children, letters were sent home with these children, requesting parents' consent to participate in the research. The final research sample consisted of those parents who indicated their willingness to participate in the research by completing a questionnaire.

Table 3.10 presents a breakdown of the 40 consent letters, which were sent home with the children who initially met the subject selection criteria. In Table 3.10 it can be seen that 32 parents indicated their willingness to participate in the research. In 8 cases consent for participation in the research was either not given or the letters were not returned to the schools. Following the parental consent, it can be seen that 32 questionnaires were issued. A total of 29 questionnaires were returned, a return rate of $91 \%$. A higher return rate was possible due to the small sample and the fact that the researcher was able to follow-up on questionnaires by keeping close contact with the participating schools. 
Table 3.10: A Summary of consent letters and questionnaires issued and returned

\begin{tabular}{|l|c|c|c|c|c|c|}
\hline $\begin{array}{l}\text { Participating } \\
\text { School } \\
\text { (sample } \\
\text { obtained) }\end{array}$ & $\begin{array}{l}\text { Consent } \\
\text { letters } \\
\text { issued }\end{array}$ & $\begin{array}{l}\text { Consent } \\
\text { NOT } \\
\text { received }\end{array}$ & $\begin{array}{l}\text { Consent } \\
\text { received }\end{array}$ & $\begin{array}{l}\text { Questionnaires } \\
\text { issued }\end{array}$ & $\begin{array}{l}\text { Questionnaires } \\
\text { returned }\end{array}$ & $\begin{array}{l}\text { Percentage } \\
\text { return } \\
\text { rate }\end{array}$ \\
\hline A:2 & 2 & - & 2 & 2 & 2 & $100 \%$ \\
\hline B:12 & 12 & 5 & 7 & 7 & 1 & $71 \%$ \\
\hline C:1 & 1 & - & 1 & 1 & 3 & $100 \%$ \\
\hline D:3 & 3 & - & 3 & 3 & 12 & $100 \%$ \\
\hline E:13 & 13 & 1 & 12 & 12 & 6 & $85 \%$ \\
\hline F:9 & 9 & 2 & 7 & 7 & 29 & $91 \%$ \\
\hline $\mathbf{4 0}$ & 40 & 8 & 32 & 32 & 12 & 2 \\
\hline
\end{tabular}

From Table 3.10 it can therefore be seen that the data for this research was obtained from 29 completed questionnaires. This means that from the sample of 40 children/parents (46\% of the total population), 29 children/parents (73\% of the research sample) eventually participated in the research.

\subsubsection{Description of research participants}

Table 3.11 presents a summary of the 29 children who were selected to participate in the research. The first two columns present the number of children participating at each school. It can be seen that 3 schools implement an Oral mode of communication and 3 schools have a Bilingual (Sign Language and English or Afrikaans) approach to communication. Table 3.11 shows that 17 (59\%) of the children were female and 12 (41\%) were male. Regarding levels of deafness, 4 children (14\%) had severe deafness, 8 children (27\%) fell within the severe to profound ranges and 17 children (59\%) were profoundly deaf. All the children had cognitive abilities within the normal ranges as indicated by their teachers. Table 3.11 further shows that 6 children were weekly boarders while 23 children were day scholars.

Parents of the 29 children were requested to complete the questionnaire. Participating parents also met the stipulated subject selection criteria. This meant that all parents had hearing within normal limits, were proficient in either English or Afrikaans to complete the questionnaires independently, and that all parents gave their consent to participate in the research through completing the questionnaire. 
Table 3.11: Presentation of children who met the subject selection criteria

\begin{tabular}{|c|c|c|c|c|c|c|c|c|c|c|}
\hline \multirow[t]{2}{*}{$\begin{array}{c}\text { School or } \\
\text { pre-school } \\
\text { unit }\end{array}$} & \multirow[t]{2}{*}{$\begin{array}{l}\text { Number } \\
\text { of } \\
\text { subjects }\end{array}$} & \multirow{2}{*}{$\begin{array}{c}\text { Mode of } \\
\text { Communication } \\
\text { at the school } \\
\\
\text { Bilingual or } \\
\text { Oral }\end{array}$} & \multicolumn{2}{|c|}{$\begin{array}{c}\text { Gender of the } \\
\text { children }\end{array}$} & \multicolumn{3}{|c|}{ Pre-lingual sensori-neural deafness } & \multirow{2}{*}{$\begin{array}{c}\text { Cognitive ability } \\
\text { Normal ranges }\end{array}$} & \multicolumn{2}{|c|}{ Boarding } \\
\hline & & & Female & Male & Severe & $\begin{array}{l}\text { Severe to } \\
\text { Profound }\end{array}$ & Profound & & Yes & No \\
\hline A & 2 & $\begin{array}{c}\text { Bilingual } \\
\text { SL/Oral }\end{array}$ & 1 & 1 & & & 2 & Yes & 1 & 1 \\
\hline B & 5 & Oralism & 2 & 3 & 1 & & 4 & Yes & 3 & 2 \\
\hline $\mathrm{C}$ & 1 & Oralism & 1 & & & & 1 & Yes & - & 1 \\
\hline $\mathrm{D}$ & 3 & $\begin{array}{l}\text { Bilingual } \\
\text { SL/Oral }\end{array}$ & 1 & 2 & & 2 & 1 & Yes & - & 3 \\
\hline E & 12 & Oralism & 8 & 4 & 3 & 2 & 7 & Yes & - & 12 \\
\hline $\mathrm{F}$ & 6 & $\begin{array}{l}\text { Bilingual } \\
\text { SL/Oral }\end{array}$ & 4 & 2 & & 4 & 2 & Yes & 2 & 4 \\
\hline & $\begin{array}{c}29 \\
100 \%\end{array}$ & & $\begin{array}{c}17 \\
59 \%\end{array}$ & $\begin{array}{c}12 \\
41 \%\end{array}$ & $\begin{array}{c}4 \\
14 \%\end{array}$ & $\begin{array}{c}8 \\
27 \%\end{array}$ & $\begin{array}{c}17 \\
59 \%\end{array}$ & $\begin{array}{c}\text { All } \\
100 \%\end{array}$ & $\begin{array}{c}6 \\
21 \%\end{array}$ & $\begin{array}{r}23 \\
79 \%\end{array}$ \\
\hline
\end{tabular}




\subsubsection{Materials used in the study}

The material used in this study consisted of a questionnaire that was specifically developed according to the aims of the research. Parents completed the questionnaires independently. All questionnaires were filled in by hand. Questionnaires were hand-delivered and collected from the schools. No postage was involved distribution and collection of the questionnaires. There was no need for any other materials or equipment in conducting the research.

The final questionnaire in English and Afrikaans consisted of three sections and forty-three questions in total. The English and Afrikaans versions of the final questionnaire are presented in Appendix D and E respectively. A covering letter, with guidelines for answering the questions, formed part of the questionnaire. This letter also assured respondents of confidentiality and anonymity of information provided. A copy of the letter in English and Afrikaans is presented in Appendix F.

\subsubsection{Questionnaire layout}

Table 3.12 presents a breakdown of the questionnaire design. The various constructs and different literacy contexts are presented. The table shows how many questions are in each section as well as the type of questions utilised to obtain the needed information. The theoretical justification for questions included in the questionnaire is presented in Appendix A. 


\section{Table 3.12: Questionnaire outline}

\begin{tabular}{|c|c|c|c|}
\hline Constructs & Type of Questions & Question numbers & Questions asked \\
\hline $\begin{array}{l}\text { Background information on the person } \\
\text { completing the questionnaire }\end{array}$ & 8 Closed questions & $\begin{array}{l}\text { Section A } \\
\text { Questions 1-8 }\end{array}$ & $\begin{array}{l}\text { Six questions relate to the age, marital status, level of education and employment status of the caregiver and two } \\
\text { questions relate to languages spoken at home. }\end{array}$ \\
\hline Background information on the deaf child & $\begin{array}{l}4 \text { Closed questions } \\
1 \text { Dichotomous question }\end{array}$ & $\begin{array}{l}\text { Section B } \\
\text { Questions 1-5 }\end{array}$ & $\begin{array}{l}\text { These questions deal with the ages and hearing status of siblings, and focus on the deaf child's age and age at } \\
\text { diagnosis, mode of communication between caregiver and child, and assistive listening devices used. }\end{array}$ \\
\hline \multicolumn{4}{|l|}{ Emergent Literacy Contexts } \\
\hline Physical and functional context: Reading & $\begin{array}{l}2 \text { Closed questions } \\
3 \text { Multiple-choice } \\
4 \text { Likert-type questions } \\
1 \text { Dichotomous question } \\
1 \text { Open-ended question }\end{array}$ & $\begin{array}{l}\text { Section C } \\
\text { Questions 1-11 } \\
\text { (11 questions) }\end{array}$ & $\begin{array}{l}\text { The questions in this section focus on the extent to which reading material is available in the home as well as the } \\
\text { family and the child's reading activities. Questions deal with the deaf child's favourite activities, the child's use of } \\
\text { printed materials, the child's interest in reading activities and participation in book-related activities. Questions also } \\
\text { focus on preferred story reading times, the child's favourite books and the frequency of story reading activities within } \\
\text { the home. }\end{array}$ \\
\hline Physical and functional context: Writing & $\begin{array}{l}1 \text { Closed question } \\
2 \text { Multiple-choice } \\
1 \text { Dichotomous questions } \\
1 \text { Likert-type question }\end{array}$ & $\begin{array}{l}\text { Section C } \\
\text { Questions } 18-22 \\
\text { (5 questions) }\end{array}$ & $\begin{array}{l}\text { These questions focus on the extent to which writing materials are available in the home and the writing activities of } \\
\text { the family. The deaf child's interest and participation in writing activities are also questioned. }\end{array}$ \\
\hline Language Context & $\begin{array}{l}7 \text { Closed questions } \\
2 \text { Dichotomous question }\end{array}$ & $\begin{array}{l}\text { Section C } \\
\text { Questions } 12-17 \\
\text { Questions } 23-25 \\
\text { (9 questions) }\end{array}$ & $\begin{array}{l}\text { These questions solicit information on the social interaction between parent and child during literacy events. It } \\
\text { questions the types of books the child reads, the communication during story reading activities, the positioning of the } \\
\text { child during reading and the extent to which the child enjoys these reading activities. Questions deal with the family } \\
\text { and siblings' participation in reading and writing with the deaf child. }\end{array}$ \\
\hline Affective Context & 2 Likert-type question & $\begin{array}{l}\text { Section C } \\
\text { Questions } 26 \text { and } 27\end{array}$ & $\begin{array}{l}\text { These two questions deal with priority afforded to literacy events and the responsibility parents assume in this regard } \\
\text { (Light and Kelford-Smith, 1993). }\end{array}$ \\
\hline Educational Context & 2 Likert-type questions & $\begin{array}{l}\text { Section C } \\
\text { Questions } 28 \text { and } 29\end{array}$ & $\begin{array}{l}\text { These questions focus on parent-school collaboration in the deaf children's emergent literacy development. It deals } \\
\text { with parental experiences in reading to their deaf child and the literacy-related advice and services parents receive from } \\
\text { their child's school. }\end{array}$ \\
\hline General & 1 Open-ended question & Section $\mathrm{C}$ & Question 30 asks parents for any additional information or observations they wish to share. \\
\hline
\end{tabular}




\subsubsection{Procedures for data collection}

For the purposes of the present research, data was collected through the presentation of a specifically developed and pilot-tested questionnaire to parents of 29 children who met the subject selection criteria. The procedures for collecting data in the present research were based on guidelines by Leedy (1989) and McMillan and Schumacher (2001) and proceeded as follows:

\subsubsection{Preparation for the fieldwork}

Prior to conducting the final stages of the fieldwork, the following preparatory work was conducted.

1. Permission to conduct research in the government schools in Gauteng was obtained from the Gauteng Department of Education, (Appendix G). As the research protocols in Kwa-Zulu Natal are different, permission to conduct research was obtained from the principal of the school concerned. Permission to conduct the research at the private units was obtained from the heads of the units.

2. Ethical clearance to conduct the research was obtained from the University of Pretoria's Ethics Committee, (Appendix H).

3. The principals of the schools were contacted to establish rapport and to request participation in the research project. Once willingness to participate was established, letters of consent were signed and a written description of the nature and importance of the research were presented to each school and unit, (Appendix I).

4. To proceed with the research fieldwork, times that were suitable to the school routines were arranged.

\subsubsection{Data collection}

The fieldwork to obtain the data needed for this research proceeded as follows:

1. Speech therapists at the participating schools were contacted to select children and parents who meet the stipulated selection criteria. 40 letters requesting participation in the research were then sent home with the children who met the selection criteria. This transmittal letter was a brief, professional letter outlining the aims of the research, requesting participation and giving assurance of confidentiality and anonymity. Parents were required to sign consent forms to indicate their willingness to participate in the research by completing the questionnaire. Informed consent was therefore obtained from all participants in the research project. The schools, units and participants were informed of all aspects of the research that could impact on their willingness to participate. The full purpose of the research was disclosed as openly and 
honestly as possible to all parties involved. The English and Afrikaans versions of these letters are given in Appendix $\mathrm{J}$.

2. A formal arrangement was made with each school and unit for the distribution of the questionnaires to the 32 parents who gave consent to participate in the research.

3. Questionnaires were compiled with a guiding letter addressed to each parent. This letter provided specific guidelines for completing the questionnaire. It also presented the researcher's contact details should parents wish to discuss questions or request clarification. Confidentiality and anonymity were emphasised. Parents were also thanked for their willingness to participate.

4. Each questionnaire was coded with a unique respondent number. Due to the nature of the questions and response modes in the questionnaire, a variation in sections of the questionnaire to different respondents was unnecessary.

5. At a time convenient to the schools and units, the researcher delivered the questionnaires for children to take home, requesting return to the school within one week. The teachers wrote a letter in the children's homework books requesting acknowledgment that the questionnaires were received.

6. The researcher collected the questionnaires from the schools and units at pre-arranged times.

7. As the present research targeted a small and very specific sample, additional efforts were made to involve those parents who failed to return the questionnaires. This involved telephonic follow-up when the questionnaires were not returned to the school within one week of distribution.

8. Data presented in the questionnaires was then coded and prepared for statistical analyses. Categories for open-ended questions were determined and coded under the guidance of a statistical advisor and a statistician. Results were then analysed according to the aims of the research.

\subsection{Data analysis and statistical procedures}

Data analysis involves a summary of data and the visual presentation of data through statistical tables and integrative diagrams. Due to the nature of the research design, descriptive statistics were implemented to analyse and describe the data obtained from the questionnaires with the specific purpose of answering the research questions. Graphical presentations of frequency distributions were presented in histograms and pie charts.

According to Hinkle, Wiersma and Jurs (1982), frequency distribution offers the researcher insight into, and understanding of, the nature of the data although it does not disclose the meaning that can 
be derived from the data. Following the analysis of data correlation statistics were conducted where appropriate to identify possible correlations between specific sets of data obtained. For these purposes Fisher's Exact Test was used due to the small sample size. Data analysis and statistics were integrated with a description and interpretation of the data with reference to the research questions.

Responses to the various questions were treated as follows:

- Responses to open-ended questions were coded according to categories determined by the nature of information parents provided. Responses were assigned to the various categories agreed upon by the researcher and the statistical advisor. Corresponding to the relevant questions, different codes were assigned to the identified categories. This coding procedure was also used for the follow-up questions, which formed part of the dichotomous-type questions. The codes assigned to the categories identified from data presented by the parents are presented in Appendix K. Although these responses were coded, the researcher was able to give specific detail regarding parental responses. This was due to the fact that the sample was small and due to the personalised nature of the responses provided.

- For closed questions and multiple-choice questions, responses were coded according to prearranged codes. Once the codes were captured into the analysis software, it was analysed to identify response patterns amongst respondents. Frequency distributions were identified and presented visually.

- Responses to ordinal questions were coded prior to ordering the responses from highest to lowest scores. This reordering process is called rank distribution (Hinkle et al., 1982). Based on this reordering, frequency distributions were identified.

- The responses to scaled questions and statement-type questions were coded according to the categories presented in the questionnaire. Data was captured by computer and then analysed to identify response patterns amongst respondents. Frequencies of response patterns were visually presented.

\subsection{Summary}

The preceding chapter described the methodology of this research project. The aims and sub-aims of the study were presented, followed by a description of the research design. The questionnaire development and pilot testing of this measuring instrument were discussed in detail with reference to various appendices. The criteria for subject selection and material used in the research process were presented. The background information on parents and children who participated in the 
research was presented. This was followed by a detailed description of the procedures for data collection. Finally, the procedures for data analyses were outlined to pave the way for the presentation and interpretation of the results obtained. 


\section{CHAPTER 4 \\ RESULTS AND DISCUSSION}

\subsection{Introduction}

Reading deficiencies, and the fact that most children with severe to profound deafness reach inadequate literacy levels, are well documented in the literature and, apart from a few exceptional children, low achievement levels have persisted for the majority of deaf children over decades of research (Webster, 2000). The focus of the present research is on emergent literacy as one variable to consider in exploring the low reading levels of deaf children.

This chapter will describe the home-based literacy experiences of severely to profoundly deaf preschoolers as perceived and presented by their hearing parents. The analysed results are visually presented and interpreted with reference to the four literacy contexts. Figure 4.1 provides an outline for the presentation and discussion of the results.

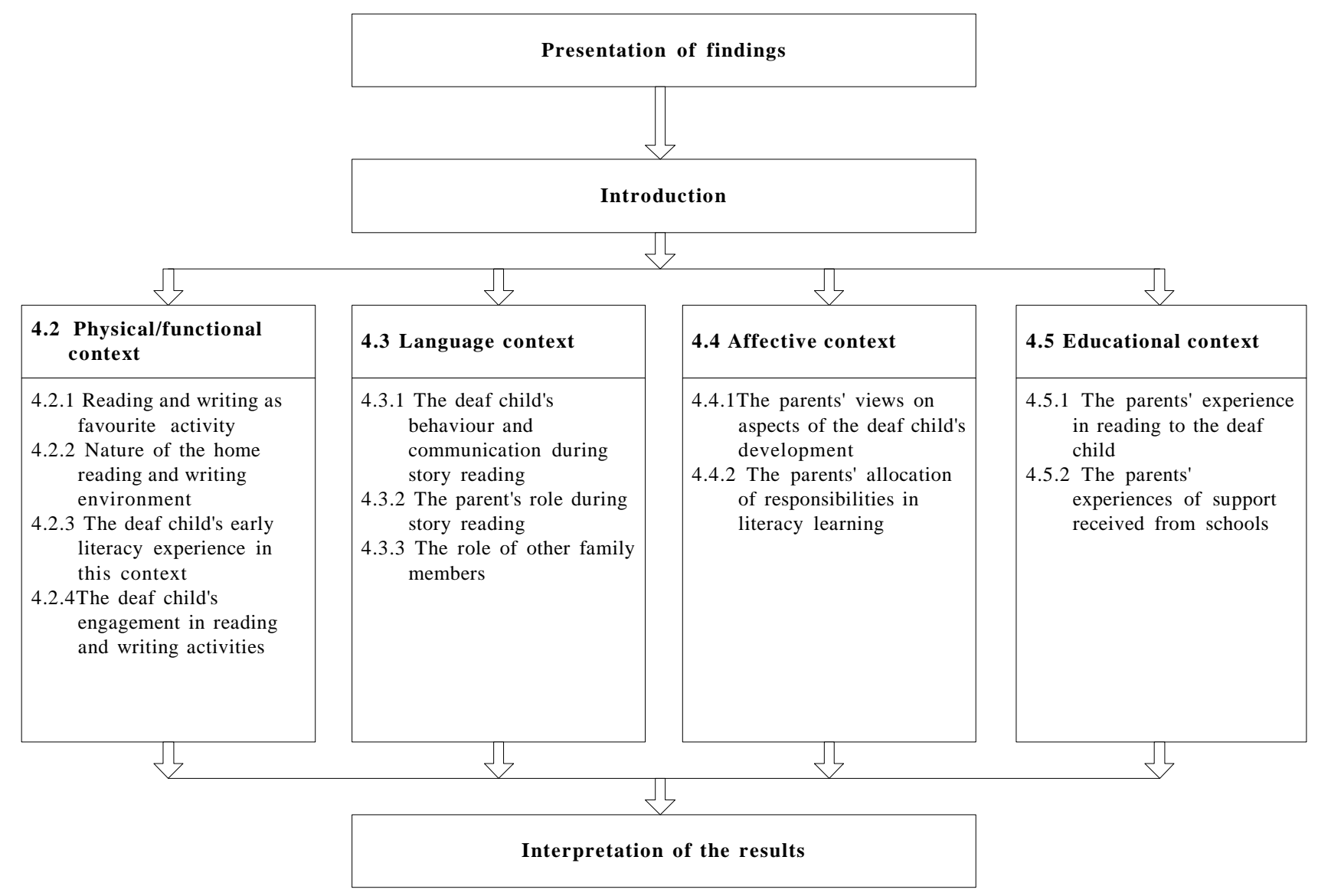

Figure 4.1: Outline for presentation and discussion of results 
The aim of this chapter is to integrate the information obtained from the questionnaires as pertaining to the literacy contexts and to present and discuss the results. Appendix L provides an outline of how all the questions in the questionnaire have been integrated into the discussion. From Figure 4.1 it can be seen that this chapter will explore the nature of the physical and functional literacy context in the homes. In the language context, the nature of communication between deaf children and their parents is described and the affective context will explore parental priorities regarding their children’s literacy development. Lastly, the educational context will present parents' needs in providing literacy experiences to their deaf children. This discussion will be followed by an integration of the results, which will highlight the trends amongst the different contexts. It must be emphasized that all the results presented are based on parents' perspectives of their deaf children's literacy development. Children were not directly involved in the accumulation of data and observations of interaction between hearing parents and their deaf children were not part of the present methodology.

\subsection{The physical and functional context}

The deaf child's interactions with literate others have the potential to create a context for learning where literacy is embedded in everyday activities. The aim of these questions was to establish whether deaf children in this survey enjoy reading and writing activities and to determine the extent to which they are exposed to literacy-rich home environments. The nature of literacy practices of family members as well as the deaf child's literacy experiences within this context were questioned. Information regarding the nature of reading activities shared between deaf children and their hearing parents was thus obtained.

\subsubsection{Reading and writing as favourite activities}

Through responding to a closed question, parents indicated their deaf children's favourite activities. The responses to this question are presented in Figure 4.2. It was encouraging to note that parents reported that looking at books, as well as reading and drawing, rated amongst their children's favourite activities. Other activities identified by parents as favourites were watching TV and playing outside. From parents' reports, it appears that the deaf children in this survey do enjoy reading activities in spite of the fact that communication barriers caused by their profound deafness can isolate them from meaningful interactive experiences with people in their environment (Williams, 1994). 


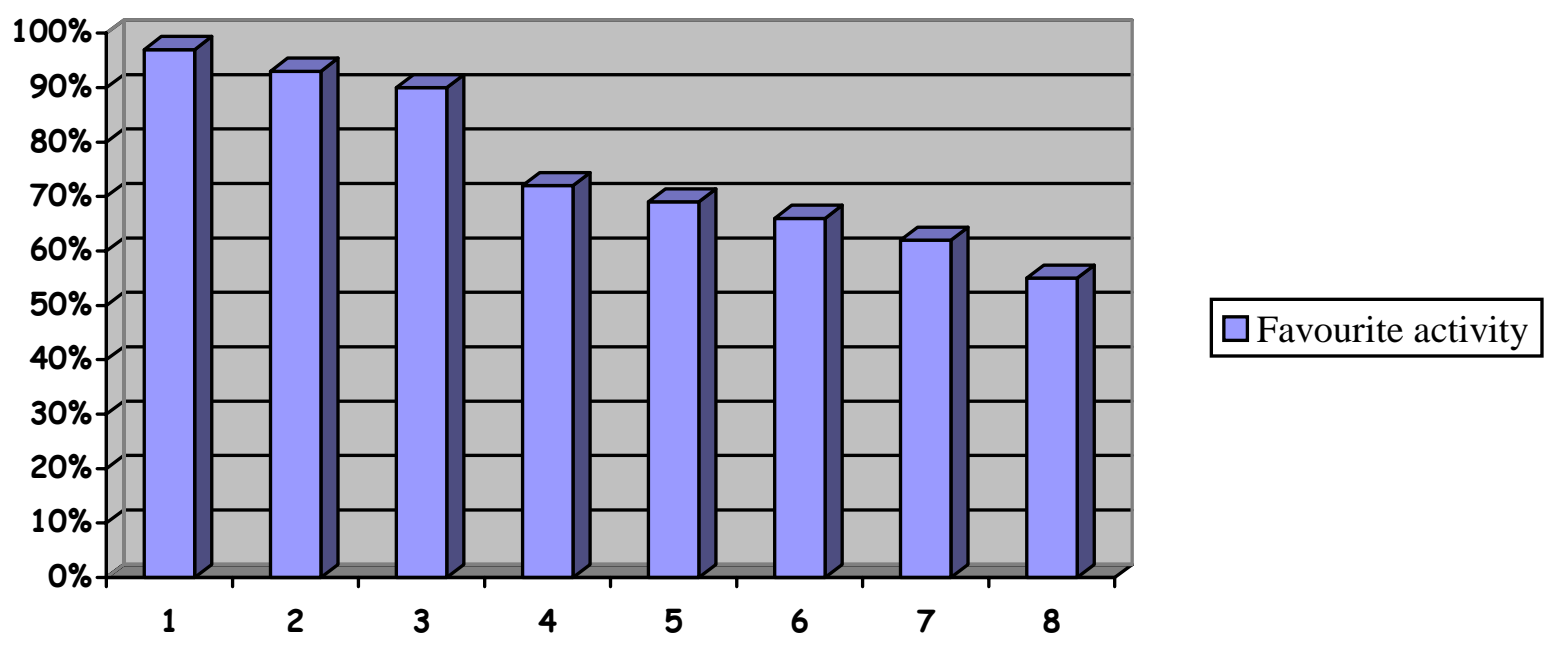

Respondents were permitted to indicate multiple responses to this question.

Percentages of $n=29$ are presented in parentheses.

$1=$ Looking at books 28 (97\%) $\quad 5$ = Drawing with others 20 (69\%)

$2=$ Playing outside $27(93 \%) \quad 6=$ Drawing alone $19(66 \%)$

$3=$ Watching TV $26(90 \%) \quad 7$ = Sport $18(62 \%)$

4 = Playing inside 21 (72\%) $\quad 8$ = Reading with an adult 16 (55\%)

Figure 4.2: Deaf children's favourite activities as reported by their parents

The results show that these deaf children enjoy writing and drawing activities independently as well as with other family members. Young children and their parents develop writing and drawing routines similar to the booksharing routines (McGee and Richgels, 2000).

With reference to reading, parents report that their deaf children enjoy looking at books as a favourite activity rather than being read to by an adult. Fisher's Exact Test was implemented to determine a possible relationship between children looking at books and children reading with an adult. The statistical analysis is presented in Appendix N. These results reveal that $41 \%$ of the deaf children in this survey like looking at books but do not enjoy reading with an adult, while 55\% enjoy reading with an adult and looking at books. Fisher's Exact p-value of 0.4483 indicated no statistically significant association at the 0.05 level between deaf children's preference to look at books rather than read with an adult.

In an open-ended question, parents were asked to indicate if they thought that their deaf children enjoyed reading with them. Figure 4.3 shows that $79 \%$ of the parents indicated that they thought their deaf children enjoyed reading with them, $14 \%$ were uncertain of their children's enjoyment of reading and 7\% did not respond to the question. 


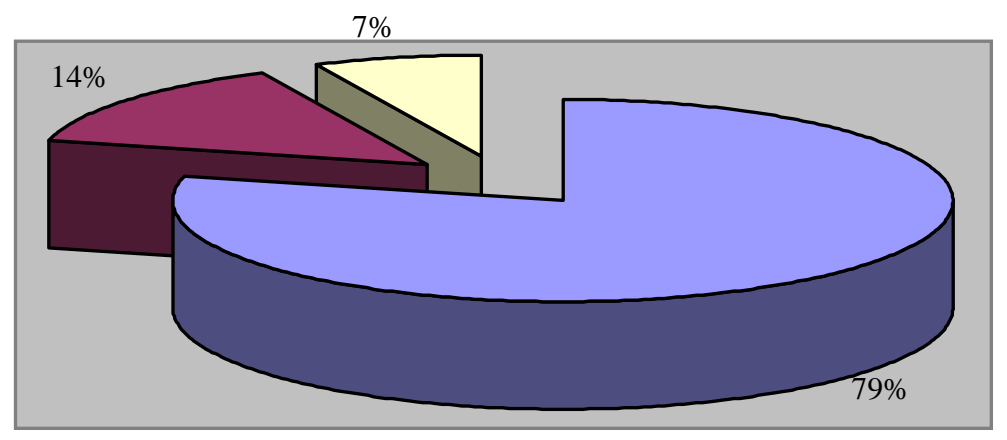

$\square$ Yes $\square$ Uncertain $\square$ No reply

\section{Figure 4.3: Deaf children's enjoyment of reading}

Many parents therefore feel that their children enjoy reading with them despite their reports in the previous section indicating that reading with an adult is not a favourite activity of deaf children. Through scaled questions, parents were asked to indicate their child's interest in reading and writing activities. 28\% of parents stated that their children had a low interest in reading while $72 \%$ felt that their children had a high interest in reading. With reference to writing, 7\% indicated a low interest in writing while most children, 93\%, had a high interest in writing and drawing activities. These results are presented in Figure 4.4.

Fisher's Exact Test was utilized to determine whether an association between levels of interest in reading and writing could be established. Statistical analysis (Appendix N) shows that high interest in reading is associated with high levels of interest in writing and drawing in 69\% of the children. The p-value for Fisher's Exact was 0.4828, and did not indicate a statistically significant relationship between reading and writing interest at the 0.05 level. 


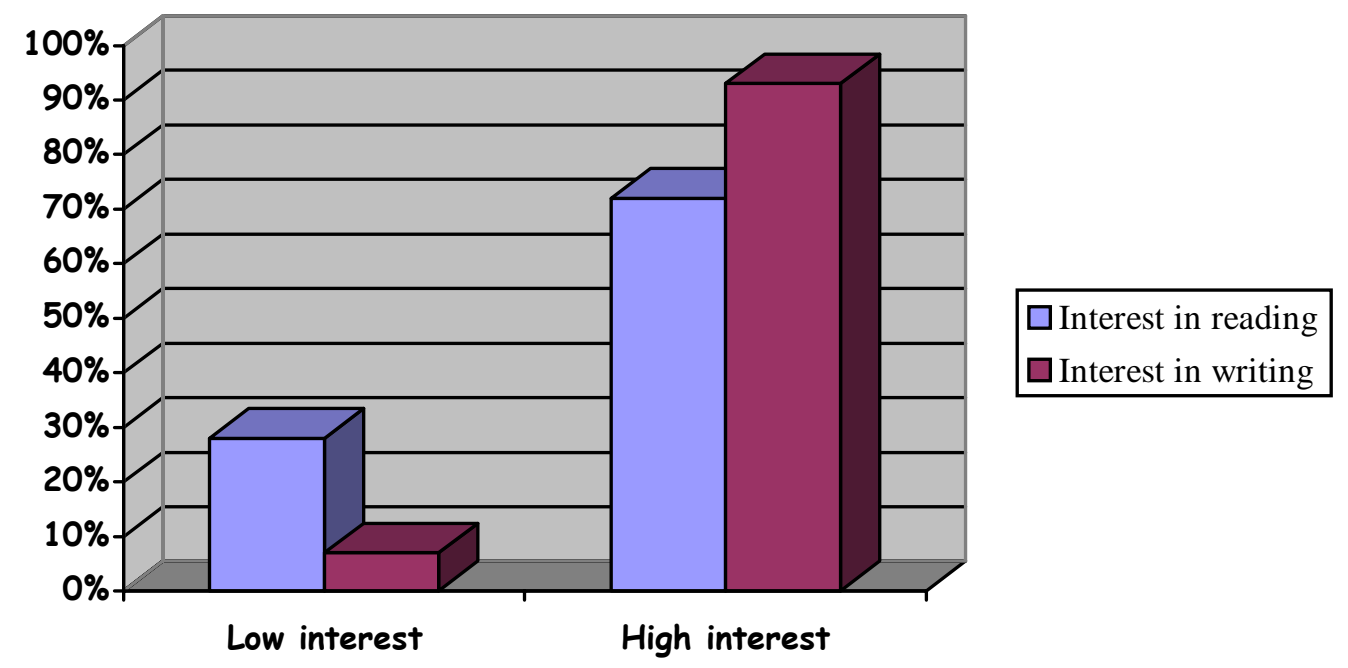

Figure 4.4: Deaf children's interest in reading and writing activities

These deaf children therefore seem to be very interested in reading and writing activities, with a slightly higher interest in writing and drawing than in reading. These results also correspond with the parents' views that reading and writing rate amongst their children's favourite activities. According to Schirmer and Williams (2003), extensive experiences with reading and writing activities rather than focusing largely on language acquisition, are an important aspect of the early development of young deaf children. According to the parents, the deaf children showed their interest in reading through a general enthusiasm for reading. Deaf children in this study reportedly initiate reading activities, actively participate in reading activities and enjoy the individual attention and shared time with their parents.

\subsubsection{The nature of the home reading and writing environment}

The extent to which reading and writing materials are available in the home and the nature of the family’s reading and writing activities were described. Morrow (1993) emphasises the need for literacy contexts, which are both functional and meaningful as they provide the best opportunities for literacy exposure and learning.

\subsubsection{Parents' reading and writing}

The family's interest in reading is presented in Figure 4.5 . The results show that $35 \%$ of parents were mostly interested in reading, $48 \%$ of parents were very interested in reading activities, while $17 \%$ of parents are only somewhat interested in reading. 


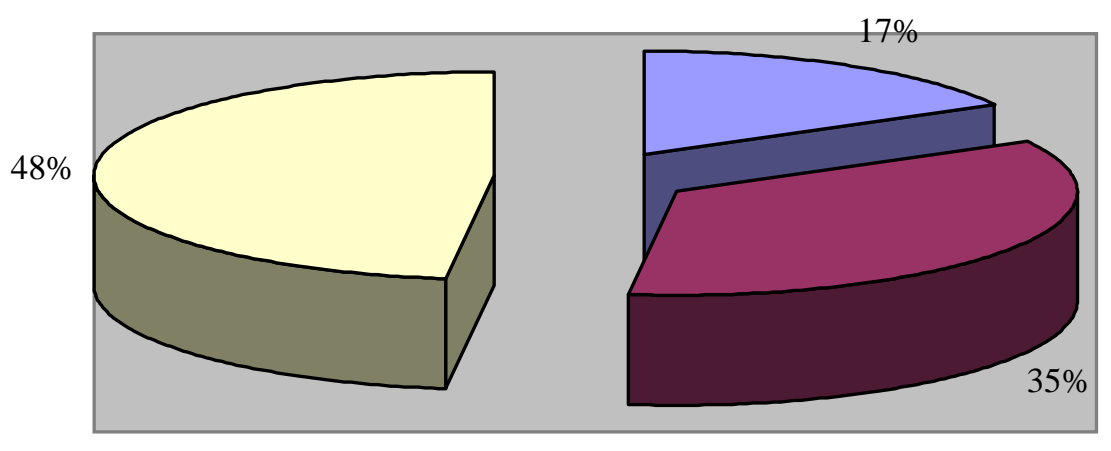

$\square$ Somewhat interested $\square$ Mostly interested $\square$ Very interested

\section{Figure 4.5: Family’s interest in reading activities}

In a separate question, 90\% $(\mathrm{n}=26)$ of families reported a high level of enjoyment in writing and drawing activities, $7 \%(\mathrm{n}=2)$ of parents did not enjoy writing and said that it was just something that had to be done. One parent (3\% of the sample) did not reply to this question.

The results therefore show that parents had a high level of interest in reading activities and that they generally enjoyed writing activities. Cairney (2003, p85) refers to family literacy as "social and cultural practices associated with written text”, which determines how literacy is constructed, developed and valued within families. Literacy is, therefore, not a unitary skill but a social practice consisting of many forms, utilised in different contexts.

In multiple-choice questions with request for further description, parents indicated the frequency with which they read and wrote in the presence of the deaf child. These results are presented in Figure 4.6 and show that parents engage in reading and writing activities on a daily basis. The parents also described the nature of the reading and writing activities. The writing activities of families included writing for household purposes, work and school-related writing as well as writing and drawing activities that included the deaf child. The functions of reading reported by parents included recreational reading, reading for information as well as school and work-related reading. 


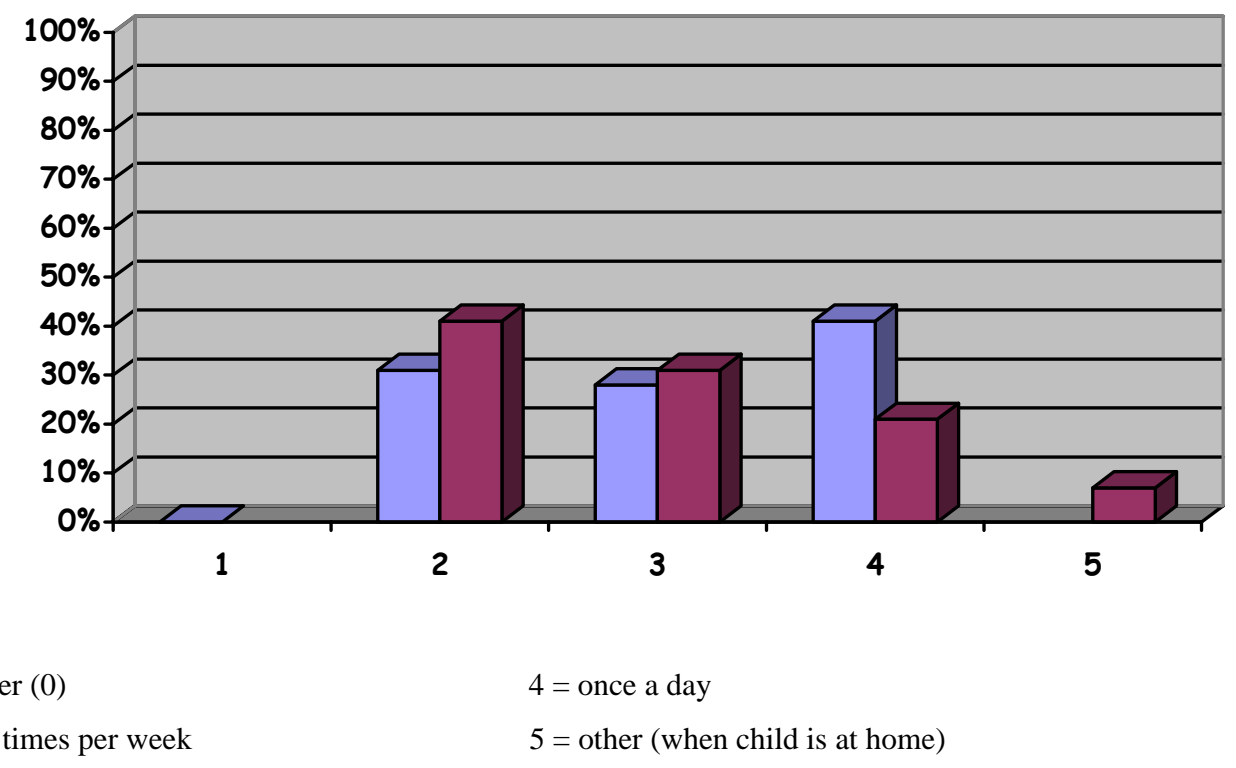

5 = other (when child is at home)

$3=$ many times a day

\section{Figure 4.6: The frequency of the family's reading and writing activities}

Deaf children are frequently exposed to reading and writing activities within the family and parents also reported that a wide range of reading and writing materials were available in their homes.

\subsubsection{Availability of reading and writing materials}

The most reported reading materials include magazines, newspapers, children's storybooks and children's picture books. The majority of families also had a range of writing and drawing materials available, which included pens, pencils, paper, Koki pens, crayons, paints as well as chalkboards and chalk. Lenhart and Roskos (2003) point out that when literacy materials are readily available in the environment, children naturally explore and interact with them.

From the results obtained, it appears that the families in this survey are actively involved in daily reading and writing activities. The deaf children are therefore exposed to good literacy models and can observe how literacy functions as part of everyday life. The fact that a wide range of reading and writing materials are available within the homes indicates that the deaf children are part of literacy rich environments. Morrow (1993) states that the availability of printed material provides an indication of the extent to which parents are able to create a 'literacy-rich' environment. As the parents in this study are readers themselves, they may be better able to engage their children in book reading activities. According to Bus (2002), such a literacy rich environment fosters a positive attitude to literacy and an early interest in books that can be maintained throughout the child's developing years. 


\subsubsection{The deaf child's early literacy experiences within the physical and functional context}

According to Truax et al (2004), children begin to assume responsibility for selecting books and activities to meet social and personal purposes as they become more personally engaged in the literacy process. Such assumptions of responsibility has also been observed in the deaf children represented in this sample, as they own books and have favourite printed texts.

Deaf children’s book ownership according to their parents is presented in Figure 4.7.

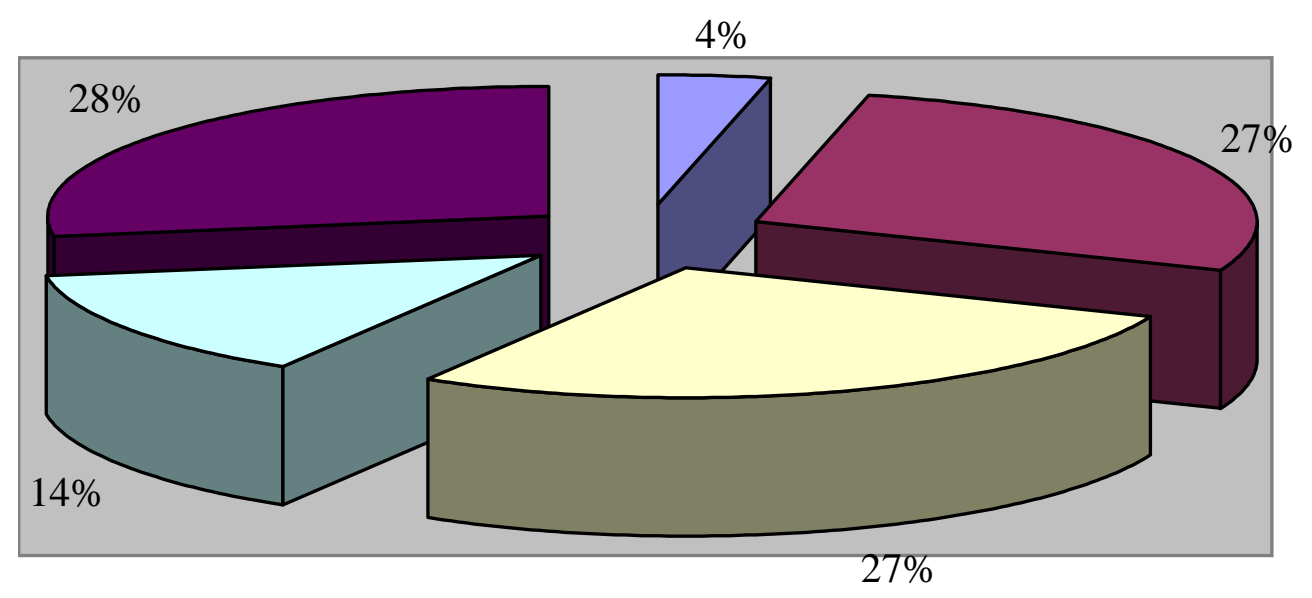

$\square$ None $\square$ 1-5 books $\square$ 6-10 books $\square 11-20$ books $\square 21$ or more books

$\mathrm{n}=29$

No books $=1(3.5 \%)$

$11-20$ books $=4(14 \%)$

$1-5$ books $=8(27.5 \%)$

21 or more books $=8(27.5 \%)$

$6-10$ books $=8(27.5 \%)$

\section{Figure 4.7: Deaf children's book ownership}

Results show that most of the deaf children in this survey owned their own books. Through frequent literacy experiences with a variety of printed text, deaf children can learn that reading is a pleasurable activity and they have the opportunity to learn bookhandling skills and to develop booksharing routines (McGee and Richgels, 2000). The presence of booksharing routines is evident from the deaf children's preferred story reading times. In response to a closed question with multiple response options available, parents reported that afternoons early evenings and bedtimes were the preferred reading times. Five parents indicated that reading does not form part of their routine and another five parents said that they read only when time is available or upon the child's request. 
In response to an open question, parents listed a range of books as their children's favourite books. These results are presented in Table 4.1. The titles presented by parents were categorised as presented in Appendix K (question5).

Table 4.1: Deaf children's favourite reading material according to their hearing parents

\begin{tabular}{|l|c|}
\hline \multicolumn{1}{|c|}{$\begin{array}{c}\text { Category of books presented as deaf } \\
\text { children favourite books }\end{array}$} & $\begin{array}{c}\text { Percentage of children who regard } \\
\text { these books as 'favourites' according to } \\
\text { their parents }\end{array}$ \\
\hline Fairy tales and fantasy stories & $9(31 \%)$ \\
\hline Simple children's stories & $7(24 \%)$ \\
\hline Picture books & $6(21 \%)$ \\
\hline Animal books & $4(14 \%)$ \\
\hline Activity books & $3(10 \%)$ \\
\hline Magazines & $3(10 \%)$ \\
\hline Rhyming books e.g. Dr Seuss & $2(7 \%)$ \\
\hline Alphabet books & $1(3 \%)$ \\
\hline Number books & $1(3 \%)$ \\
\hline Child has no favourite storybooks & $1(3 \%)$ \\
\hline
\end{tabular}

Parents provided multiple responses to this open-ended question.

Percentages calculated from n=29

Table 4.1 shows that the deaf children enjoy a variety of printed material. According to Robb (2003), when children listen and interact with a variety of books, they learn the structure of stories and narrative non-fiction. These results must however be viewed in conjunction with the parents' preferred reading texts when reading to their children. Parents' responses to a closed question regarding what they usually read to their children are presented in Figure 4.8. 


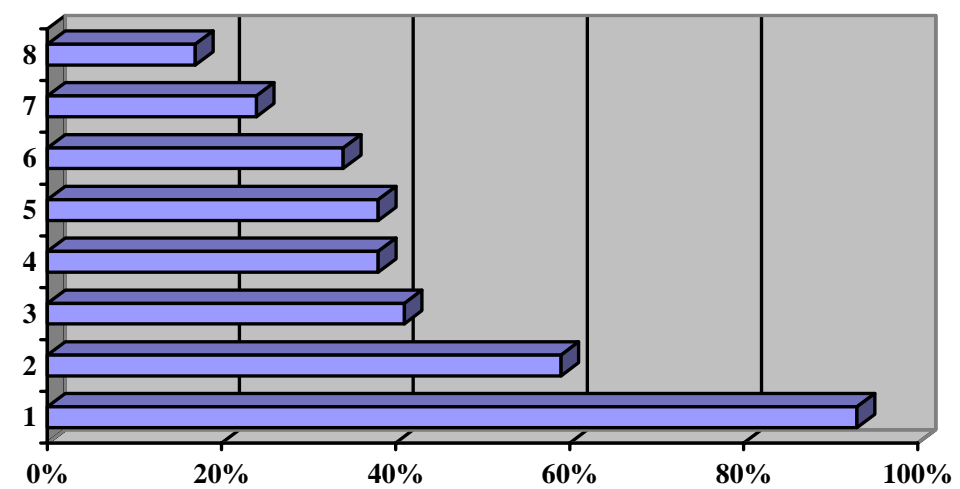

$\square$ Books parents usually read to their deaf children

Respondents were permitted to indicate multiple responses to this question.

Percentages of $n=29$ are presented in parentheses.

$1=$ Picture books 27 (93\%)

4 = Alphabet books 11 (38\%)

7 = Children's magazines 7 (24\%)

2 = Simple story books $17(59 \%)$

5 = Fairy tales $11(38 \%)$

8 = Children's non-fiction 5 (17\%)

3 = Nursery rhymes 12 (41\%)

$6=$ Number books $10(34 \%)$

Figure 4.8: Reading material parents usually read to their children

Parents' most preferred reading texts include simple stories and picture books, which do not feature as the children's favourite text as highlighted in Table 4.1. It is interesting to note that nursery rhymes are not a favourite of deaf children but that parents often read these books to their children. From the results obtained, it appears that there is a difference between the reading material parents present to their children and what they perceive as their children's favourite texts. This may have a negative impact on the children's motivation to engage in story reading with their parents.

It is suggested that parents choose texts that are easier to present to their deaf children. This may be the reason why picture books feature as the reading material most preferred by parents when reading with their deaf children. Nikolajeva (2003) states that illustrated picture books are the most essential source of reading experience for young children as the child is challenged to assemble meaning from different means of communication. For young deaf children, a crucial outcome of their early literacy experiences with books and other kinds of print is that they can learn that books and other print materials communicate meaning. It is encouraging to note that in this survey picture books are followed by simple storybooks as the preferred text to read to deaf children. This suggests that parents do attempt to present more communicatively challenging texts to their children.

As the children in this sample own books and have a range of favourite storybook titles it, was also relevant to determine whether deaf children participate in other book-related activities. Results 
showed that $61 \%$ of deaf children rarely borrow books from the library, whereas only $39 \%$ of children visit the library either weekly or monthly. A similar response pattern was obtained regarding visits to the bookshop. Whitehurst and Lonigan (2002) highlight research which shows that other aspects of the home literacy environment e.g. number of books in the home, library visits and parents own print exposure, were related to children's development of vocabulary skills. In this context, it is also relevant to highlight the fact that only $38 \%$ of families have computers available in their homes. Computer literacy is becoming increasingly important as part of conventional literacy and early exposure to computer related reading will also become more important for young deaf children (Smith, 2005). These additional book-related activities therefore need to be encouraged in families with deaf children.

\subsubsection{The deaf child's engagement in reading and writing activities}

According to parents, the deaf children in this survey regard reading and writing as favourite activities and have a high level of interest in these activities. Figure 4.9 shows that the deaf children frequently engage in both reading and writing activities.

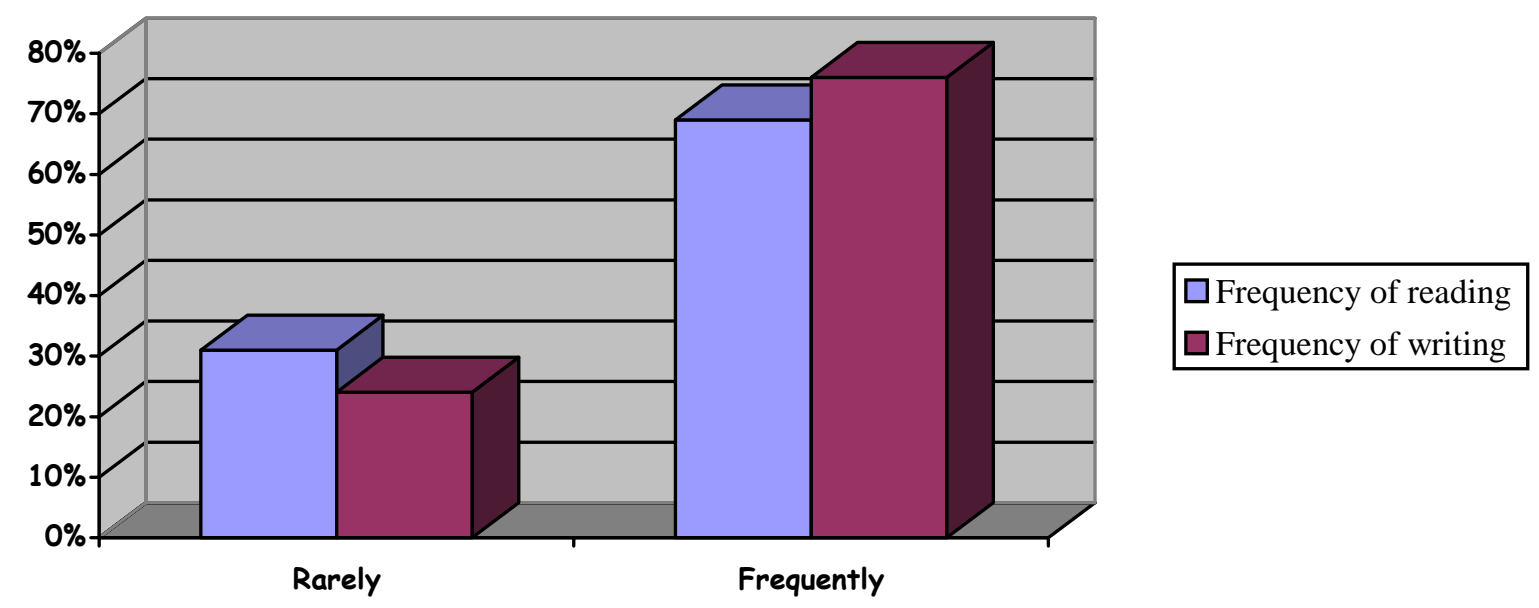

\section{Figure 4.9: Frequency of engagement in reading and writing activities by the deaf child}

Frequent engagement in reading and writing activities may be fostered by the fact that both printed materials, and materials for writing and drawing are readily available in their homes. Fisher's Exact Test was utilised to determine whether frequent engagement in reading are associated with frequent engagement in writing and drawing. In $57 \%$ of cases, frequent reading is associated with frequent writing and drawing. The results are presented in Appendix N. The p-value for Fisher's Exact $(\mathrm{p}=$ 0.3518) did not reveal a statistically significant association at the 0.05 level to show that if children frequently engage in reading, they also frequently engage in writing and drawing activities. 
Based on the observations of deaf children's high interest and frequent engagement in reading activities, the nature of these activities is explored in more depth. Many authors (Williams, 1994; Gillespie and Twardosz, 1997; Watson, 1999; Justice and Lankford, 2002) highlight the fact that shared storybook reading provides an essential opportunity for children to learn concepts about print and it is a useful context within which to promote language acquisition and emergent literacy knowledge. The reciprocal relationship between language and literacy learning, especially for the deaf child, cannot be ignored. Webster (2000) states that access to story reading and mediation of stories by adults are critical factors for both deaf and hearing children.

Parents were requested to indicate the time their deaf children spent on reading activities by responding to a statement-type question. Results are presented in Figure 4.10. The following conclusion are drawn from the results obtained in this survey:

- The majority of hearing parents do not frequently read to their deaf children. This finding must be seen in relation to the fact that parents indicated that deaf children in this sample do not regard reading with an adult as a favourite activity (refer to Figure 4.2).

- A high percentage of children enjoy looking at books with an adult. This is evident too from parents' reports that most deaf children in this survey initiate literacy activities with other members of the family. It may also be related to the reports from parents that picture books are preferred reading material so that parents and children often look at books together in a communicatively less demanding context.
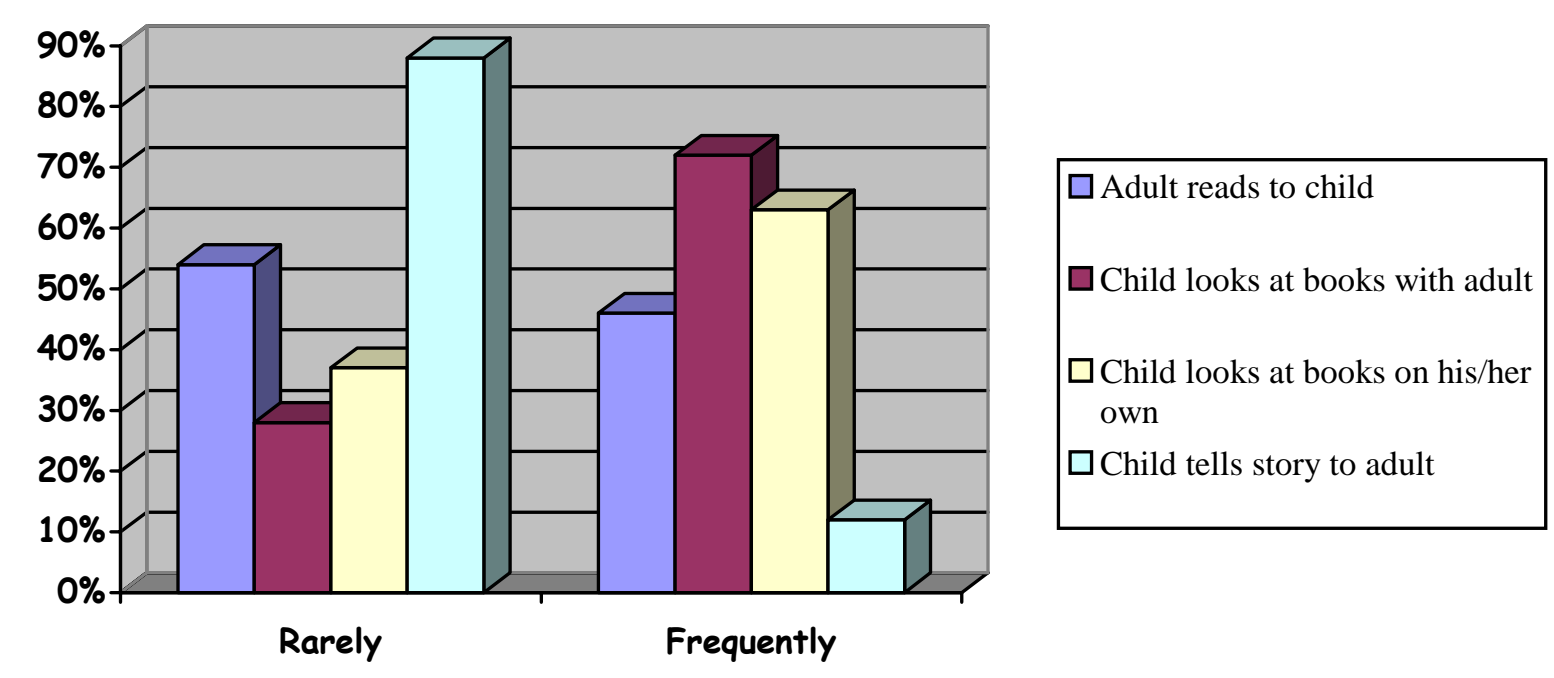

For purposes of comparison,these results have been condensed into the categories "rarely" and "frequently". For an exact breakdown of the results obtained see Appendix N. The limitations of condensing results are acknowledged but for purposes of comparison the present format was needed.

Figure 4.10: The nature of reading activities and the frequency of engagement in these activities 
- According to the parents, the deaf children in this sample enjoy looking at books on their own. This corresponds with earlier reports that deaf children regard reading as a favourite activity (see Figure 4.2), have a high interest in, and frequently engage in these activities (see Figure 4.4).

- Deaf children in this study do not appear to tell stories from books to their parents. This may be related to the communication barriers that exist between hearing parents and their deaf children. Webster (2000, p.136) explains that due to the problems of constructing a shared language with other hearing family members, "the majority of deaf children may not have the same opportunities to converse about picture books or to acquire concepts and structures of stories”.

It is encouraging to note that parents look at books with their deaf children. As McGee and Richgels (2000) point out, frequent storybook interaction can be related to a special feeling generated from the closeness of parents and children associated with books. The children in this sample probably experience this closeness by looking at books with their parents rather than through actual story reading. It is suggested that hearing parents should read to their deaf children more often. Gillespie and Twardosz (1997) have found that frequent story reading can increase deaf children's interest, engagement and independence in story reading, and limited exposure to story reading may thus have a negative impact on this aspect of early literacy learning.

Justice and Lankford (2002) highlight that shared book reading is a powerful tool for emergent literacy development because it is a context that is meaningful, interesting and motivating to the pre-school child. Results obtained in this survey show that story reading between the deaf children and their hearing parents is an area of concern that may need focus in early intervention of young deaf children. Watson (1999) emphasises that an understanding of books and story structure can be made accessible to deaf children. Parents therefore need to be encouraged to move beyond simply looking at pictures and naming objects to presenting story structure to their deaf children.

\subsection{The language context}

The aim in this context is to determine the nature of communication between hearing parents and their deaf children around text-related activities. The role of other family members in these literacy related activities is also considered. 


\subsubsection{The deaf child's behaviour and communication during story reading activities}

The behaviour of deaf children during story reading activities, as reported by their parents, is presented in Figure 4.11. It is interesting to note that few deaf children have an attentive listening attitude during story reading activities and that the highest scores were present for looking at and pointing to pictures. This corresponds with results obtained in the physical and functional context where preference for picture books and looking at books became apparent. Little negative behaviour of deaf children is reported and parents make little reference to communicatively interactive behaviours on part of the deaf children during story reading.

Hearing parents' reports of their deaf children's participation during story reading in the present study is consistent with other research findings which show that interactions involve a reduction in both the quantity and cognitive complexity of the deaf child's input. Interactions generally involve more adult control over turn-taking and the topics of conversation with deaf children taking fewer initiatives and receiving more directives, questions and imperatives (Meadows 1996, in Webster and Heineman-Gosschalk, 2000).

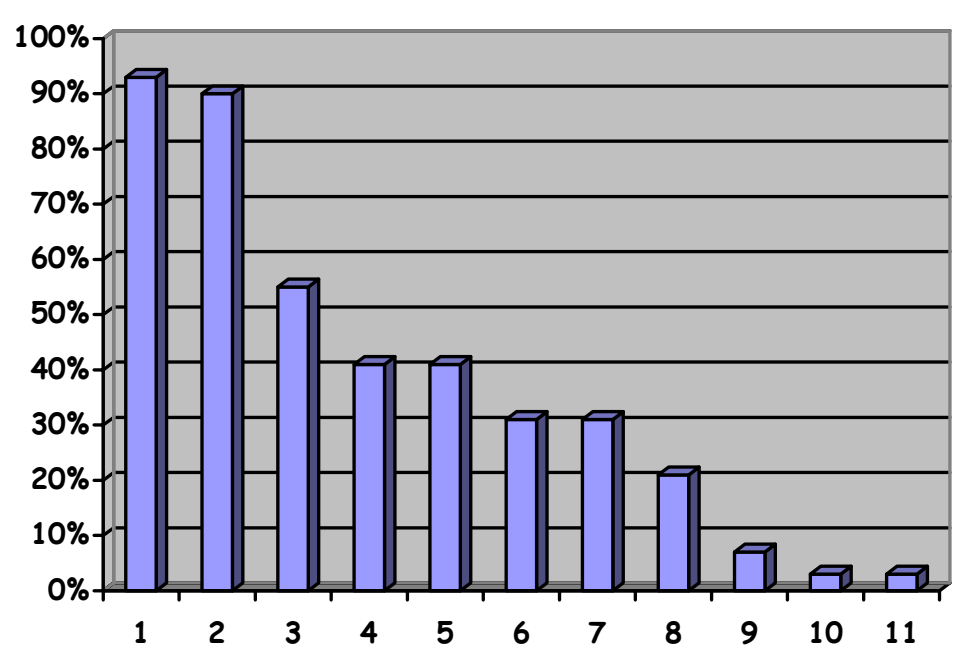
$\square$ Deaf child's role during story reading
activities

Respondents were allowed to mark more than one answer to this closed question. Proportions were calculated from the sample of 29 respondents

$1=$ Looks at pictures 27 (93\%)

7 = Listens attentively 9 (31\%)

$2=$ Points to pictures 26 (90\%)

$8=$ Tries to guess what will happen next 6 (21\%)

$3=$ Turns the page 16 (55\%)

9 = Other: Talks about the picture 2 (7\%)

4 = Answers questions 12 (41\%)

$10=$ Shows little interest 1 (3\%)

5 = Asks questions 12 (41\%)

$11=$ Tries to tear the pages $1(3 \%)$

$6=$ Grabs the book away 9 (31\%)

Figure 4.11: The deaf child's behaviour during story reading activities 
Through response to a closed question, parents indicated their observations of their deaf children's communication during story reading activities. These results are presented in Table 4.2. The results show that the deaf children in this survey communicate mainly through gestures, pointing, facial expressions and body language. The role of pointing is also evident in the children's behaviour during story reading as is presented in Figure 4.11. These observations are consistent with the findings of Williams (2004) where, deaf children used facial expression, gesture and pantomime as a means of communicating experiences.

Table 4.2: Deaf children's communication during story reading activities

\begin{tabular}{|l|c|}
\hline Variables presented & $\begin{array}{l}\text { Parents' indication of their deaf } \\
\text { children's communication during in } \\
\text { story reading }\end{array}$ \\
\hline Facial expressions and body language & $\mathbf{1 7 ~ ( 5 9 \% )}$ \\
\hline Gestures and pointing & $\mathbf{1 3 ( 4 5 \% )}$ \\
\hline Vocalisation & $\mathbf{1 1 ( 3 8 \% )}$ \\
\hline Speech & $\mathbf{1 0 ( 3 5 \% )}$ \\
\hline Sign Language & $\mathbf{9 ( 3 1 \% )}$ \\
\hline Sign and speech & $\mathbf{5 ( 1 7 \% )}$ \\
\hline Signs and vocalisations & $\mathbf{5 ( 1 7 \% )}$ \\
\hline No communication & $\mathbf{1 ( 3 \% )}$ \\
\hline
\end{tabular}

Respondents were permitted to present multiple responses to this question.

Percentages calculated from $n=29$ are presented in parentheses.

In section B of the questionnaire, parents indicated that their preferred mode of communication with their deaf children involved speech and gesture (see Table 3.8). The complexity of the communication between parents and children has an influence on the quality and quantity of language the children receive during story reading sessions. It appears that nonverbal communication, in the form of gesture forms an integral part of communication between the parents and children in this survey.

The language and communication difficulties between hearing parents and their young deaf children within the story-reading context need careful consideration. In an attempt to explore emergent literacy as a factor to consider in the acquisition of literacy skills in deaf children, 
Webster and Heinemann-Gosschalk (2000, p26) state that rather than locating the literacy difficulties within the deaf child, "the emphasis should shift to promote deaf children's meaningmaking in reading and writing”. If it is accepted that language and literacy acquisition develop concurrently, the focus should shift to the nature of the interaction between hearing parents and their deaf children within a literacy environment that is conducive to the development of these skills. The literacy environment therefore includes issues described in the physical and functional context as well as the interactions constructed around text as targeted in the language context.

Within the literacy environment, Light and Kelford-Smith (1993, p19) highlight the importance of positioning during story reading activities so that "positioning maximises the intimacy and social closeness of the experience” and, at the same time, facilitates communication. Deaf children rely on their visual channel for communication and, therefore, the constant shifting between book and reader can cause discontinuity in story reading (Heinemann-Gosschalk and Webster, 2003). Parents in this study indicated that the most common seating arrangements for story reading are sitting beside the child on the bed or on a sofa. Parents also read to their children with the children sitting on their laps, or in fewer instance sitting at the table, lying in bed or sitting on the floor. The seating arrangements favoured by parent in this survey show little awareness of the importance of visual clues during communication as it favours neither good eye contact during reading, nor optimal conditions for lip reading.

\subsubsection{Hearing parents' role during story reading activities}

With the emphasis on interaction during literacy related activities, the way in which hearing parents engage with their deaf children becomes relevant. Webster and Heinemann-Gosschalk (2000, p27) state that "when children come to reading and writing, they depend on adults to facilitate their path into learning how their systems for oral and signed meaning-making meet the medium of lettered representation in literacy”.

The responses of parents in the present study regarding their role in story reading activities show a high degree of directive interaction which present information rather than share meaning within the story context. As presented in Figure 4.12 it can be seen that parents often point to pictures and label them, or ask children to label and point to pictures while telling the story. This is consistent with the deaf children's means of communication through vocalisation, gestures and pointing as presented in Table 4.2. 


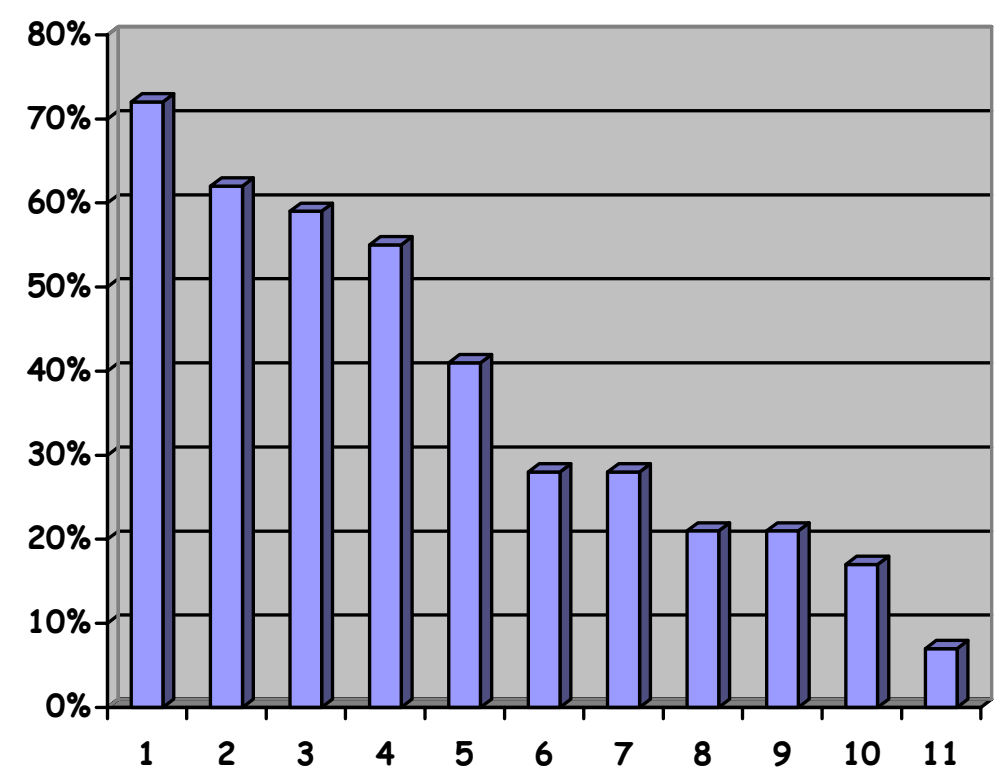

$\square$ Adults role during story reading activities

Respondents were allowed to mark more than one answer to this closed question. Percentages calculated from $n=29$ are presented in parentheses

$1=$ Point to the pictures and tell the story 21 (72\%)

$2=$ Point to the pictures and label them 18 (62\%)

$3=$ Ask the child to label the pictures 17 (59\%)

$4=$ Asks the child to point to the picture 16 (55\%)

$5=$ Point to words 12 (41\%)

$6=$ Read the text $8(28 \%)$

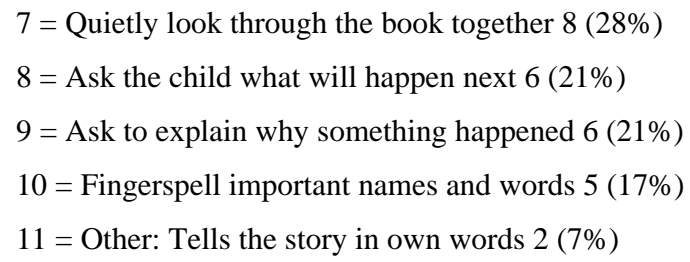

Figure 4.12: Nature of parents' participation during story reading activities with their deaf children

Adult interactive behaviour has a significant effect on children's reading responses so that deaf children will engage more frequently in conversation around text when approached with low control strategies. The child's use of pointing and gesture may therefore also relate to how adults communicate during text related activates. The role of deaf children's language development and their parent's ability to communicate with their children in this context cannot be ignored.

It is interesting to note that there are few requests from the deaf children to interact in the text by answering questions and predicting what will happen. This may also be due to the fact that the children's language competence does not allow more interactive contributions to the text and hence parents remain more concrete in their own presentations of the stories. It may also be related to the types of questions parents ask and the fact that they use mainly picture books when reading to their children. 
Nittrouer and Burton (2003) highlight the fact that some of the language problems experienced by deaf children may arise from an experiential deficit rather than due to the sensory deficit. It is essential that parents understand the role of world knowledge in literacy development. Parents of deaf children, therefore, need to be comfortable in their abilities to provide meaningful language experiences to their children through shared book reading and through meaningful engagement in writing activities. From the results obtained in this survey it is clear that the parents of these deaf children will benefit from further guidance regarding their role in shared storybook readings with their children.

\subsubsection{The role of other family members in the literacy activities of deaf children}

Children who are read to regularly by parents, siblings and other individuals in the home are more likely to become early readers and show a natural interest in books (Morrow, 1993). In a dichotomous question about children's interaction with other family members around text, 27 (93\%) of the parents indicated that their deaf children were exposed to social interaction around reading and writing with a range of literate mediators in their home environments. One parent stated that the deaf child does not interact with other family members around text and one parent did not answer this question. Results indicate that most of the literacy interaction involves the mothers of the children, but that fathers, siblings and grandparents also play a role in literacy related activities.

The deaf children in this survey are therefore exposed to a range of literate role models, which has a positive impact on fostering interest in, and motivation for engagement in reading and writing activities. The interaction between siblings around text reveals a different kind of access to literacy knowledge and skills in the family setting. The repetitive nature of reading and writing between siblings allows for the clarification of basic concepts about print, the elaboration and extension of these ideas into more subtle meanings and understandings that build literacy knowledge (Lenhart and Roskos, 2003). If older hearing siblings model literacy and engage in literacy, showing that it is pleasurable and worthwhile, then the deaf sibling is sure to adopt such a positive model of literacy. The nature of sibling participation in literacy activities is presented in Table 4.3.

The results in Table 4.3 show that, according to the parents, sibling interaction between hearing children and the deaf child mostly involves drawing and interaction around drawings. In this survey, hearing siblings did not often read stories to the deaf child. It appears that the hearing 
siblings prefer activities with the deaf child which are less demanding in terms of language and communication.

Table 4.3: Sibling's participation in reading and writing activities with the deaf child

\begin{tabular}{|l|c|}
\hline Variables presented & $\begin{array}{l}\text { Respondent's indication of sibling } \\
\text { participation in reading and writing. }\end{array}$ \\
\hline $\begin{array}{l}\text { Siblings draw with the deaf child and interact around } \\
\text { and talk about the drawings }\end{array}$ & $\mathbf{1 8 ~ ( 6 2 \% )}$ \\
\hline Siblings act out stories for or with the deaf child & $\mathbf{8}(\mathbf{2 8 \% )}$ \\
\hline Siblings read to the deaf child & $\mathbf{6 ~ ( 2 1 \% )}$ \\
\hline $\begin{array}{l}\text { No participation due to siblings being much older and } \\
\text { not living in the same household. }\end{array}$ & $\mathbf{6 ( 2 1 \% )}$ \\
\hline No siblings, deaf child is an only child & $\mathbf{5 ( 1 7 \% )}$ \\
\hline Siblings sing nursery rhymes to the deaf child & $\mathbf{4 ( 1 4 \% )}$ \\
\hline
\end{tabular}

Respondents were permitted to present multiple responses to this question.

Percentages calculated from $\mathrm{n}=29$ are presented in parentheses.

In this context it was also relevant to determine who mostly initiates literacy-related activities within the home environment. The responses to this closed question are presented in Figure 4.13. From the results presented in the survey it can be seen that deaf children mostly initiate literacyrelated activities in the home, followed by their mothers. It is interesting to note that older siblings also play a significant role in the initiation of literacy activities at home.

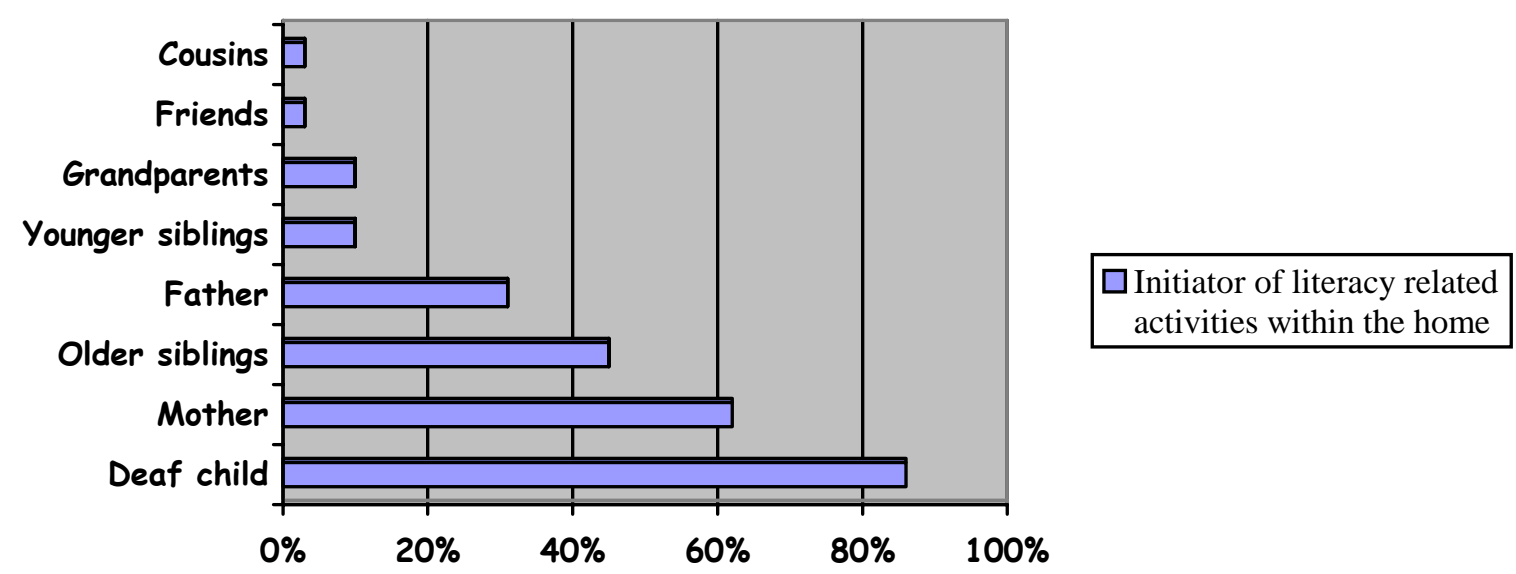

Respondents were permitted to present multiple responses to this question.

Percentages calculated from $\mathrm{n}=29$

Figure 4.13: Initiator of reading and writing activities within the home 
This corresponds with the findings by Light and Kelford-Smith (1993), where 93\% of AAC children in their study were the initiators of literacy activities. The results therefore reflect a positive relationship between deaf siblings and their deaf family members, as the children are confident to initiate reading and writing activities within the home.

From a social-interactive perspective, the nature of communication between the deaf child and his/her literate role models during literacy-related activities needs careful consideration. The present results show that the deaf children in this sample use mainly nonverbal means of communication (as in Table 4.2), with a reported high preference for looking at books on their own and drawing alone (see Figure 4.2). Hearing parents reported that they use gesture and speech in communicating with their deaf children (as in Table 3.9). Parents in this survey rely mostly on picture books as reading material to present to their deaf children (Figure 4.8) and pointing and labelling form an important part of text-based interaction with their deaf children. Siblings clearly show a preference for activities with the deaf child that involves less demanding communicative interaction. These results seem to indicate that the nature of text-based interaction between the parents and their deaf children may need further investigation. It thus appears that the deaf children in this sample are exposed to literacy-rich environments but the information presented by the parents shows that these children are deprived in terms of the quality, quantity and complexity of language input that they receive from the literate role models whom they interact with.

\subsection{The affective context}

Parental priorities and expectations regarding literacy activities are powerful predictors of children's reading achievement (Dunn 1981, in Light and Kelford Smith, 1993). The aim of questions in this section was to determine parental priorities regarding their deaf children's literacy development and their attribution of responsibilities in their deaf children's literacy acquisition.

\subsubsection{Parents' views on aspects of their deaf children's development}

According to Swanwick and Watson (2005), parental attitudes to reading and writing set the tone for successful book-sharing at home. Parents should therefore create a supportive and encouraging environment where they interact with their children in reading and writing activities. Parents were requested to rate the importance of aspects of their children's development, as they perceived it. Figure 4.14 presents a summary of what parents rated as the most important aspects of their deaf children's development. 
Parents rated all the aspects of development presented with varying degrees of importance, except with regards to Sign Language (see Figure 4.14). The spread of the results do however indicate that parents place more emphasis on the importance of speech, spoken language development and interaction with friends as opposed to the importance of literacy development. The use and understanding of Sign Language are not regarded as important in spite of the fact that many of these children are in bilingual (speech and Sign Language) educational settings.

In an open-ended question, parents were asked to indicate why the rated aspects of development were regarded as important. Parents referred mainly to the importance of speech and language acquisition in the lives of their deaf children and to the children's ability to communicate effectively in a hearing world. No parent made reference to the development of reading and writing skills and the importance of these skills in the life of a deaf child (see Appendix K, question 26).

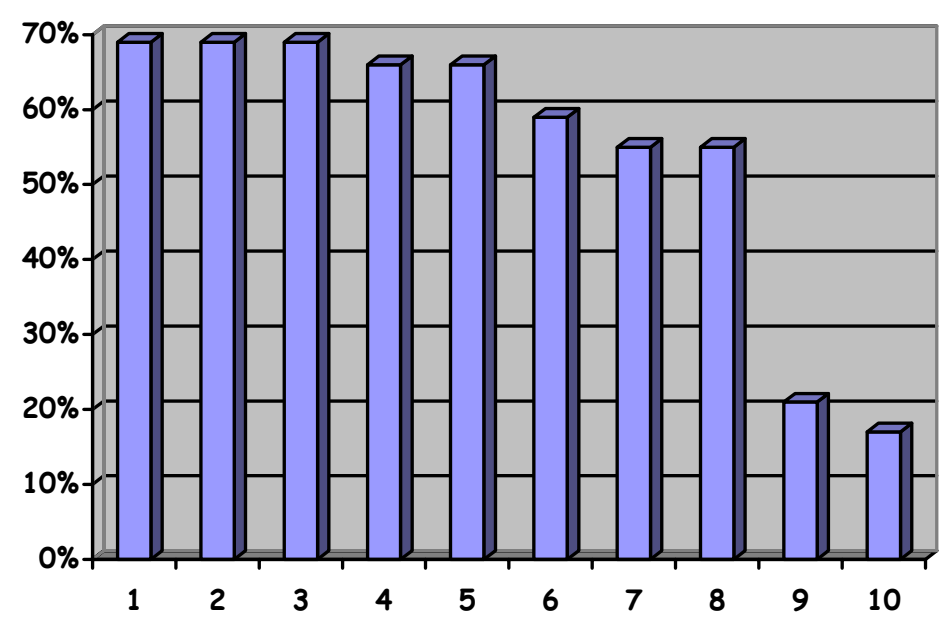

$\square$ Aspect of deaf child's development rated as important by hearing parents
Percentages calculated from $\mathrm{n}=29$

1 = Speech development 20 (69\%)

2 = Use of spoken language 20 (69\%)

3 = Making friends 20 (69\%)

4 = Spoken language comprehension 19 (66\%)

5 = Exposure to books 19 (66\%)

$$
\begin{aligned}
& 6=\text { Ability to communicate } 18(62 \%) \\
& 7=\text { Learning to read } 17(59 \%) \\
& 8=\text { Learning to write } 16(55 \%) \\
& 9=\text { Use of Sign Language } 6(21 \%) \\
& 10=\text { Understanding of Sign Language } 5(17 \%)
\end{aligned}
$$

Figure 4.14: Parental ratings of most important aspects of their deaf children's development

These observations are of concern as Morrow (1993) says that the emotional and motivational contexts reflect parents' attitudes toward literacy and their aspirations for their children's literacy development and achievement. If parents do not highly prioritise the acquisition of reading and writing skills in the same way as they prioritise language and communication, a nurturing climate for the development of these skills cannot be provided. Ewoldt (1985) states that successful 
booksharing depends on a positive supportive environment where parents expect their children to become literate.

\subsubsection{Parents' allocation of responsibility in their children's literacy development}

Through a rating-type question parents showed who they thought had the most responsibility in teaching their deaf children to read and write. These results are presented in Figure 4.15.

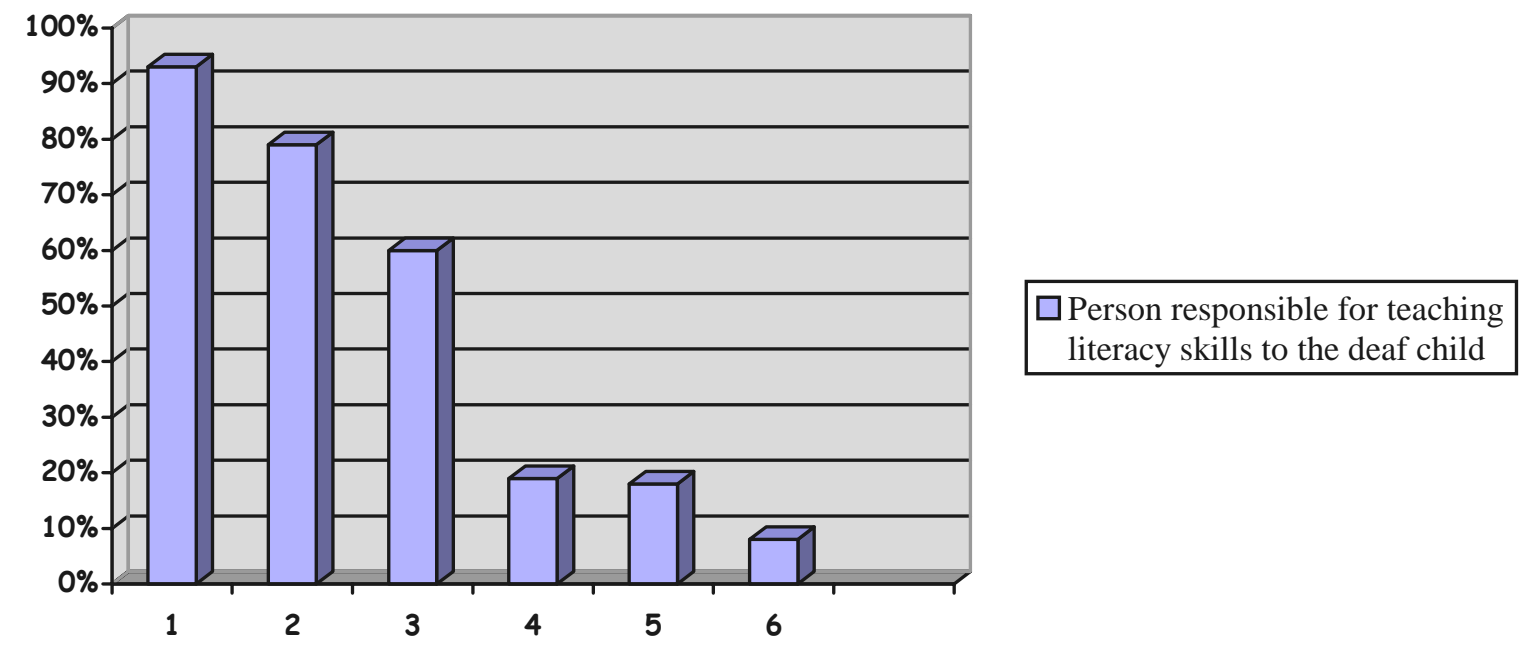

Percentages calculated from $\mathrm{n}=29$

$1=$ Teacher 27 (93\%)

$$
\begin{aligned}
& 4=\text { Siblings } 4(19 \%) \\
& 5=\text { Grandparents } 4(18 \%) \\
& 6=\text { Friends } 2(8 \%)
\end{aligned}
$$

3 = Father 25 (60\%)

Figure 4.15: Parent's allocation of responsibility in teaching deaf children to read and write

These results show that parents allocate the most responsibility for the literacy development of their children to the teachers. The roles of the mother and the father in the literacy development of their children are however also acknowledged. It is suggested that in the present context parents still view reading and writing as a set of mechanical skills which have to be taught by the teacher.

It is suggested that a paradigm shift is needed in parents' perspectives regarding language acquisition and literacy learning in their deaf children. A shift to a socio-cultural perspective necessitates an understanding that literacy is not a set of rules to be taught in an educational setting. The acquisition of reading and writing skills is fostered within literacy-rich environments where deaf children are interactively engaged in literacy-related activities by literate adults with high expectations of their children’s literacy development (Ewoldt, 1985; Swanwick and Watson, 2005). 
It appears that the parents in the present study are still unaware that, as indicated by Teale and Sulzby (1986), literacy development is a socio-interactive process that occurs simultaneously with language development. Furthermore, parents need to understand the reciprocal relationship between these modalities rather than view language development as a precursor to literacy development. As indicated by Webster and Heineman-Gosschalk (2000, p38), the problems of literacy development “shift away from within-child factors on to adult strategies and how meaning can be negotiated”. The results obtained regarding interaction between deaf children and the literate role models within their home environment clearly point to the need for more emphasis on constructive interaction around text. The separation between language acquisition and literacy learning belongs to the past. It is suggested that this "shift", from focus on the child to interaction between the child and significant others in the home and educational environment, may be one of the key issues in address literacy acquisition in deaf children.

\subsection{The educational context}

Makin (2003) points out that due to the changing nature of society, children's early literacy experiences will take place in various contexts - home, community, and a range of early childhood settings. It is suggested that continuity and communication between these environments will be in the best interest of the child's early acquisition of literacy skills. Positive and supportive literacy environments within home and school must be created to provide a firm foundation for the acquisition of early reading and writing skills in young deaf children. The aim of this section of the questionnaire was to determine parents' experiences in reading to their deaf children to determine the nature of support parents received from their children’s schools.

\subsubsection{Parents' experiences in reading to their deaf children}

In response to a statement-type question, parents in the present survey were positive in relating their experiences of reading to their deaf children. Parents reported that they enjoyed reading to their children and that they felt confident in their abilities to do so. They did not experience a lack of time to read to their deaf children and felt that they had sufficient knowledge on how to read to their children, with adequate access to appropriate reading material. Parents did however indicate that they find it difficult to read and sign at the same time and that they are sometimes unsure if their deaf children understand what is read to them. Regarding communication within literacy related activities, parents did not experience difficulty in communicating with their children and they did not find it difficult to maintain eye contact during reading interaction. 
These results are in contrast to the results that were obtained in the language context (see Figures 4.11 and 4.12 as well as Table 4.2) where the limitations in text-based interactions between parents and their deaf children became clear. As the deafness of most of the children in this survey have been identified prior to the age of 24 months (see Table 3.8), these parents may have participated in early intervention programmes which have guided them in the communication needs of their children. These parents are however not presently meeting the communicative demands of textbased interaction, in spite of their indications that they are comfortable in reading to their children.

The fact that parents did not experience any difficulties in providing literacy experiences to their children may therefore be explained with reference to two opposing points. On the one hand, parents may be well informed about reading and communicating with their deaf children. This is a possibility, given that many of these children are in school environments where supportive teams of teachers and therapists work with parents and children. On the other hand, parents may not be fully aware of the communication interaction and meaning-making strategies needed to foster the development of early reading and writing skills within the home-environment. Parents may also not be aware of the importance of seating arrangements, eye contact and communication during textbased interaction. This is a possibility because results of this survey pertaining to the language context have clearly revealed limitations in the communication between hearing parents and their deaf children in interactions around text. Within this context it is relevant to consider the extent to which parents are aware of and have accepted the role of emergent literacy development in young deaf children. This will clearly have an impact on the guidance parents will receive from teachers and the goals that will be set for the early literacy development of young deaf children.

\subsubsection{Parents' experiences of support received from their children's schools}

Parents were also asked to indicate their needs in terms of support and guidance they received from their children's schools. The results are presented in Figure 4.16. 


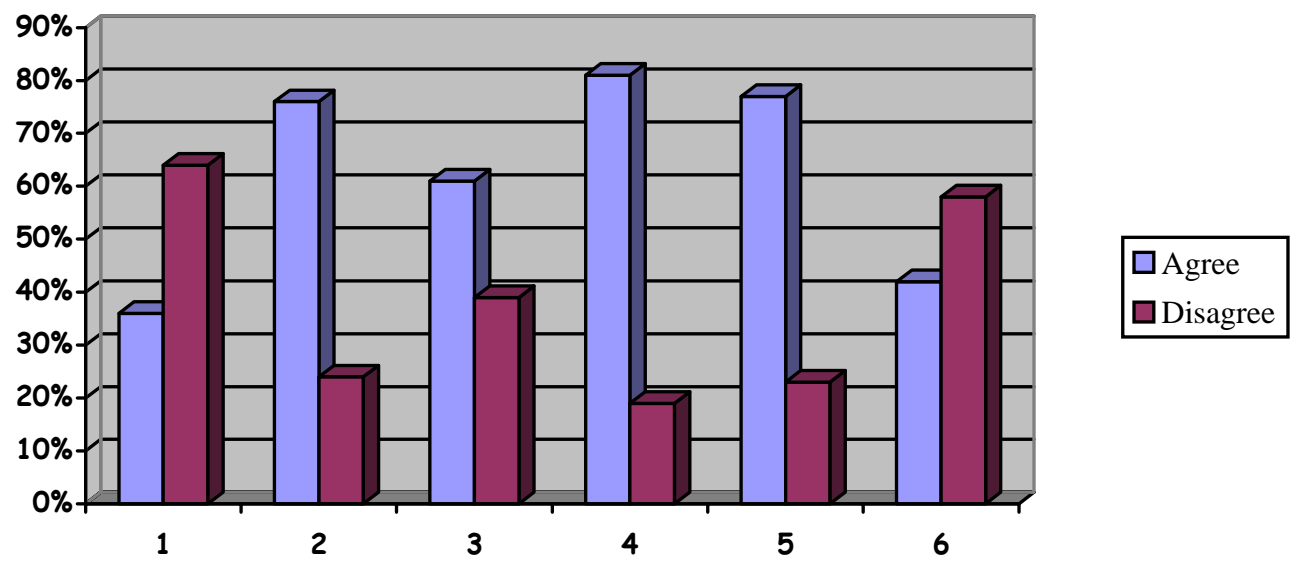

$1=$ Parent participates in workshops at school demonstrating reading methods with deaf children

2 = Parent receives individual advice on how to read to their deaf child at home

$3=$ Parent receives advice from teacher on which books to read to the deaf child

$4=$ The school offers a library service

5 = Parent receives advice on communication methods to use while reading at home to the deaf child

$6=$ Parent is involved in setting individual teaching targets for the deaf child's literacy development.

Figure 4.16: Respondents' experiences of school support

Parents reported that they receive individual advice on how to read and which books to read to their deaf children, as well as communication methods to use when reading to their deaf children at home. Some parents expressed a need for demonstrations of reading methods with deaf children and for involvement in setting teaching targets for their deaf children’s literacy development.

Parents' needs for more information on reading methods, coupled with the limitations identified in the communication interaction between hearing parents and their deaf children show that parents are not yet able to meet the literacy needs of their deaf children. The children's frequent participation in reading and drawing activities as a favourite pastime and the indication that the children often initiate these activities, show that the deaf children are eager and ready for more interactive communication around text. The teacher can thus fulfil a supportive role by guiding both parents and children within the context of early literacy development.

With the emphasis on language development in the intervention of young deaf children it is suggested that the role of early literacy development has not yet received the recognition that is needed. This survey focused on the perspectives of parents only and has not included contributions by the deaf children or from their teachers. The need for a triadic approach to early literacy thus emerges which shows that the early literacy development of young deaf children must include the 
parent (and other literate role models within the home environment), the deaf child and the educational context (teachers and therapists).

It is suggested that the reciprocal relationships between the partners in this triad will determine the nature of the deaf child's early literacy experiences at home and at school. Truax et al (2004) emphasise that each child emotionally, socially and cognitively goes about the process of learning language and literacy in ways that reflect individuality. Teams of parents and teachers and other personnel should therefore address the individual educational special needs of deaf children.

\subsection{Integration of results obtained}

Based on the preceding discussion, the following important points must be highlighted:

- According to hearing parents in this survey, reading and writing rate amongst deaf children's favourite activities and the children show a high degree of interest in these activities. As a result, the deaf children frequently engage in literacy-related activities.

- The parents of the deaf children in this survey indicate that their deaf children prefer to look at books rather than to read with an adult. This is in spite of the fact that most parents feel that their deaf children enjoy reading with them. Results do however indicate that most parents in the present survey do not frequently read to their deaf children (see Figure 4.10).

- Hearing adults, themselves, frequently engage in literacy-related activities at home and a range of reading and writing materials are available to the deaf children. Parents showed an interest in reading (Figure 4.5) and frequently engaged in their own reading and writing activities for work and recreational purposes (see Figure 4.6 and Appendix K: Questions 3 and 19). The role of literacy in these families' homes may be related to their educational and employment levels (see Table 3.7). Morrow (1993) does however point out that it is a literacy-rich environment, not parents education, occupation or socio-economic level that correlates most highly with children's early literacy ability.

- The deaf children in this sample, reportedly own books and have favourite books they prefer. From the results it appears that parents' preferred texts for their children do not always coincide with the children's favourite books.

- Following parents' responses, it appears that the deaf children's behaviour and communication during text-related interaction consist of limited communicative interaction and much reliance on pointing and gesturing. It appears that parents' communication with their children is also restricted in terms of quality and quantity. Sibling interaction around 
text further confirms limited communication during text-related interaction as siblings also favour activities that are communicatively less demanding.

- Parents in this survey seem to place higher priority on the acquisition of speech and spoken language communication than on the development of reading and writing skills. Greatest responsibility for the teaching of these skills to the deaf child is assigned to the teacher.

- From Figure 4.14 it can be seen that the parents in this survey do not regard Sign Language as a priority in the development of their deaf children. This is further confirmed by the parents' indications that speech and gesturing are their most preferred mode of communication with their deaf children (see Table 3.8). It is interesting to note that Sign Language is mentioned as another language used in the home by only $28 \%$ of the parents (as in Table 3.7).

- Parents responses indicate that they are comfortable in communicating with their deaf children and that they enjoy reading to their children.

- Parents do express a need for more hands-on training in reading methods to use with their deaf children. Parents also express the need to be involved in setting literacy learning targets for their deaf children.

These points will form the foundation for the conclusions presented in chapter 5 .

\subsection{Summary}

This chapter presented the results that were obtained from the 29 questionnaires, which were completed by the participants in this research. The results were presented and interpreted with reference to the four literacy contexts, which were identified in chapter 2 and formed the foundation of the methodology presented in chapter 3. The results were also discussed with reference to current literature. Lastly, the core results obtained from the various contexts are presented. 


\section{CHAPTER 5 \\ CONCLUSIONS AND \\ RECOMMENDATIONS FOR FUTURE RESEARCH}

\subsection{Introduction}

This chapter provides the conclusions drawn from the results obtained in the survey. The implications of the research are also discussed. The present research is critically evaluated. Finally, recommendations for future research are presented.

\subsection{Conclusions drawn from the results}

The ability to read and write increases an individual's likelihood of academic success, career advancement and opportunities for personal fulfilment in advanced societies. In school settings, reading ability has been linked to general achievement, vocabulary growth and beyond the bounds of the classroom, reading ability has been linked to employability and income levels (Koppenhaver et al 1991b). Improved literacy skills in today's society are a high priority for deaf people. The difficulties of deaf individuals in attaining functional literacy skills are an ongoing concern for professionals working in this field.

The purpose of this research was to describe the home-based literacy experiences of deaf preschoolers and their hearing parents. Data was obtained from participants through the completion of a questionnaire. Four literacy contexts were identified as relevant to the description of early literacy experiences.

Early home-based literacy experiences form the foundation for the later acquisition of conventional literacy skills. Parents of deaf children play a pivotal role in providing early literacy experiences to their children in a context that is conducive to the acquisition of these skills. A young deaf child's early literacy encounters must include experiences with both reading and writing materials in a context where the child is confident to experiment with literacy-related activities, and where the child can observe the role and function of literacy in everyday life. The present research highlights the role of parents within this context and the results obtained reflect parent's observations of their children's literacy experiences. The research results also present parents' accounts of their own involvement in their children's literacy learning. 
Parents of deaf children in the present research, serve as adult literacy role models for their children as they frequently engage in reading and writing activities in the presence of the deaf child. Deaf children also observe other family members engage in literacy related activities and the children participate with siblings and other family members in this regard. From observing the role of literacy in everyday life, a positive attitude to literacy can be fostered. The literacy environment is further enriched by the availability of a variety of reading and writing materials and the fact that most of the children in this sample have their own books and favourite texts.

Although results highlight the enjoyment of reading and writing-related activities by both parents and deaf children, certain limitations regarding text-based interaction have been identified. The results indicate that not all parents in this sample regularly read to their children and that children generally prefer to interact with books on their own rather than being read to by an adult. Siblings of the deaf child showed preference for literacy-based interactions with the deaf child that are communicatively less demanding. It can thus be concluded that the language and communication difficulties that exist between parents, family members and the deaf child have an impact on the nature of interaction during text-based interaction.

From the information provided by parents, the limitations in text-based interaction between parents and deaf children are clear. Due to the nature of the deaf child's language and communication development, parents cannot map text-based activities on an established language (Swanwick and Watson, 2005). This will clearly have an impact on the quality and quantity of the deaf child's early literacy experiences in the home environment. Based on the results obtained in this survey, it is suggested that the quality and quantity of communication interaction that deaf children in this sample are exposed to, may not meet the demands of the children's early literacy needs.

Parents further indicate that spoken language and communication development in their deaf children are of higher priority than the acquisition of literacy skills. This may be related to the emphasis on language acquisition and communication in the early intervention programmes of deaf children. In this context, the need for literacy and language development to be viewed as two sides of the same coin becomes apparent. Although parents do acknowledge their role in their children's literacy learning, they still assign most responsibility in teaching literacy skills to the teacher. In this context, it appears that parents are not fully aware of the role of emergent literacy as part of the development of the young deaf child. 
In relation to spoken language and communication development, the parents in this survey do not regard the use and understanding of Sign Language as a priority in their deaf children's development. Parents indicated that Sign Language is not often used in communication between them and their children. From the results obtained there seems to be a discrepancy between parents' regular use of nonverbal communication (signs and gestures) and their views of the role of Sign Language in their children's development. Parents' reported low regard for Sign Language may further highlight the communication difficulties between the parents and the deaf children during literacy-based activities.

Parents in this survey, furthermore, reported little difficulties in reading to their deaf children. It is suggested that parents do not understand the broader implications of text-related activities, which include both reading to and writing/drawing with their deaf children. It seems that reading and drawing activities are currently interwoven with everyday life without the same priority as language acquisition and communication skills.

In summary, the parents who participated in this research are part of educational settings where good support in terms of their young deaf children's development, is available to them. These parents appear to have some insight into the language and literacy needs of their children. The research has, however identified areas of weakness in the literacy-based interaction between the parents and their children. This area is the essence of text-based interaction as it provides the foundation for the development of young deaf children's ability to derive meaning from text. It is suggested that in an attempt to address the literacy needs of deaf children, more emphasis is needed on the early acquisition of literacy skills and the specific role that parents have to play in engaging in meaningful text-based interaction with their children in a literacy-rich environment with high expectations for literacy development. Parents also need to be sensitised to the role of Sign Language in the language and literacy acquisition of their deaf children.

The present research therefore highlights that emergent literacy of deaf children is an area that needs consideration in the literacy development of deaf children. This research has, through information provided by the parents, identified areas of strength and weakness in the home-based literacy experiences of the deaf children in this sample. It is suggested that early literacy experiences of deaf children at home and at school, are factors that need consideration in endeavours to improve the literacy skills of deaf children. The field of emergent literacy and 
deafness is still young and further research into all aspects of early literacy development of young deaf children is needed.

\subsection{Critical evaluation of the study}

Both the positive and negative aspects of the study are discussed below.

- A parent questionnaire can provide valuable information regarding the physical and functional literacy context at home, as well as with reference to parents' needs and experiences, regarding their children's literacy development. A limitation of using parent questionnaires is that it provides information from the parent's perspective only. Whereas such information is valuable, it cannot be used to gain specific information regarding interactive aspects between parents and children. Parent questionnaires must therefore not be used in isolation, but have to be combined with observations of parent-child text-based interaction to obtain a more representative picture of deaf children's home-based literacy experiences.

- A methodological constraint of this study is the small sample size $(n=29)$. The sample did however include all children who met the criteria for subject selection at the schools targeted. This had an impact on the statistical analysis that could be performed, as correlations were restricted to the use of Fisher's Exact Test for small samples. In this regard, the present research is more of an exploratory study.

- In spite of the methodological and questionnaire limitations, the results obtained in this research depict trends similar to those identified in the literature. From this sample, valuable conclusions can thus be drawn regarding the nature of their home-based literacy experiences with indications for further intervention.

- The participants in this research were from schools for the deaf and units for hearing and language-impaired children in urban areas. For this reason results can be applied to this group only.

- The early literacy development of children include the acquisition of both reading and drawing /writing skills. Due to the complex interrelationship between reading and language development in deaf children, the present research placed more emphasis on reading exposure and communication around text. A description of early literacy skills must however include both reading and writing skills of the child. 


\subsection{Future research}

Recommendations for further research based on the present research results are as follows:

- Further research into the nature of text-based interaction between deaf children, hearing parents and siblings is needed. Such research will identify the relationship between the communication needs of the deaf children and the nature of the activities parents and siblings provide within literacy-based interaction.

- It is suggested that the text-based communication between hearing parents and signing children may be more challenging due to parents’ unfamiliarity with Sign Language. Further research into the needs and expectations of hearing parents using Sign Language in literacy-based interaction is needed to highlight the difficulties parents may experience within this context.

- From the present research results, parents indicated that they do not highly prioritise the role of Sign Language in the development of their deaf children. Further research into hearing parents' attitudes towards Sign Language in the early development of their young deaf children will be invaluable.

- Parents in the present research indicated a need for more specific guidance on how to read to their children. A future study could investigate the extent to which the information and guidance provided by teachers fulfil parents’ needs for information regarding literacy-based interaction with their young deaf children.

- Information and communication technologies such as the Internet are rapidly redefining the nature of literacy, thus requiring new skills and insights to read, write and communicate. At present, computing remains heavily text-dependent thus placing greater demands on the reading skills of the deaf. A need for research into the role of computers and computer literacy as part of the development of early literacy skills of deaf children is important.

- Early literacy skills include both reading and writing skills. Within the pre-school deaf population emphasis is easily placed on reading acquisition due to the relationship with language learning. Further research is however needed into the role of writing and drawing in the emergent literacy development of young deaf children.

\subsection{Summary}

The conclusions to this research were presented with reference to the aims of the study. This was followed by a critical evaluation of the study and a presentation of the implications of the research. Lastly, recommendations for future research are stated. 


\section{REFERENCES}

Akamatsu, C.T., \& Andrews, J.F. (1993). It takes two to be literate: Literacy interactions between parent and child. Sign Language Studies, 87, 333-360

Alant, E. (2005). Issues in graphic symbol communication. In E. Alant \& L.L. Lloyd (eds). Augmentative and Alternative Communication and Severe Disabilities: Beyond Poverty. (p108130). London: Whurr Publishers Ltd.

Andrews, J.F., \& Taylor, N. E. (1987). From sign to print: A case study of picture book "reading “ between mother and child. Sign Language Studies, 56, 261-274.

Bracken, B.A., \& Barone, A. (1991). State of the art procedures for translating, validating and using psycho-educational tests in cross-cultural assessment. School Psychology International, 12, 119-132

Blume, S. (2003). How does technology affect the quality of life of deaf children? Paper presented at the European Days of Deaf Education, Orebro, Sweden. Conference proceedings: Signed Bilingualism -What does the concept mean today? May 2003, 47-54.

Boudreau, D. (2005). Use of a parent questionnaire in emergent and early literacy assessment of pre-school children. Language, Speech and Hearing Services in Schools, 36, 33-47.

Bus, A.D. (2000). Joint caregiver-child storybook reading: A route to literacy development. In S.B. Neuman and D.K. Dickinson (eds). Handbook of Early Literacy Research (p179-190). New York: The Guilford Press.

Cairney, T.H. (2003). Literacy within family life. In N. Hall, J. Larson and J. Marsh (eds). Handbook of Early Childhood Literacy (p85-96). London: Sage Publications

Clark, M. D. (2002). Interdisciplinary perspectives on context, cognition and deafness: an introduction. In M.D. Clark, M. Marshark \& M. Karchmer (eds). Context, Cognition and Deafness. (p1-5). Washington D.C.: Gallaudet University Press. 
Delport, C.S.L. (2002). Quantitative data collection methods. In: A.S. de Vos, H. Strydom, C.B. Fouché \& C.S.L. Delport (eds). Research at grass roots. For the social sciences and human service professions. ( $\left.2^{\text {nd }} \mathrm{ed}\right) .(\mathrm{p} 165-196)$. Pretoria: Van Schaik.

Dodici, B.J., Draper, D.C., \& Peterson, C.A. (2003). Early parent-child interactions and early literacy development. Topics in Early Childhood Special education, 23(3), 124-136.

Erting, L., \& Pfau, J. (1997). Becoming bilingual: facilitating English literacy development using ASL in preschool. Laurent Clerc National deaf Education Centre Web site: http://clerccenter.gallaudet.edu. Pre-college National Mission Programs, Gallaudet University, Washington, D.C.

Ewoldt, C. (1985) A descriptive study of the developing literacy of young hearing impaired children. Volta Review, 87(5), 109-126.

Fouché, C.B. (1998). Data collection methods. In: A.S. de Vos (ed). Research at grass roots. A primer for the caring professions (p152-177). Pretoria: Van Schaik

Gaustad, M. G., \& Paul, P.V. (1998). Instruction and First-language literacy. In P.V. Paul (ed). Literacy and Deafness. The Development of Reading and Writing and Literate Thought (p181-235). USA: Allyn and Bacon.

Gaskins, I.W. (2003). A multidimensional approach to beginning literacy. In D.M. Barone and L.M. Morrow (eds). Literacy and young children: Research based practices (p45-60). New York: Guilford Press.

Gillen, J., \& Hall, N. (2003). The emergence of early childhood literacy. In N. Hall, J Larson and J. Marsh (eds). Handbook of Early Childhood Literacy (p3-12). London: Sage Publications Ltd.

Gillespie, C., \& Twardosz, S. (1997). Storybook reading intervention with children at a residential school for the deaf. American Annals of the Deaf, 142(4), 320-332.

Gioia, B. (2001). The emergent language and literacy experiences of three deaf pre-schoolers. International Journal of Disability, Development and Education, 48(4), 411-428 
Haupt, E. (2001). The iconicity of selected picture communication symbols for rural Zulu-speaking children. Unpublished Master's dissertation. Pretoria: University of Pretoria

Heineman-Gosschalk, R., \& Webster, A. (2003). Literacy and the role of parents of deaf children. Deafness and Education International, 5 (1), 20-38.

Hinkle, D.E., Wiersma, W., \& Jurs, S.G. (1982). Basic Behavioural Statistics. Boston: Houghton Mifflin Company.

Justice, L. M., \& Lankford, C. (2002). Preschool children’s visual attention to print during storybook reading: pilot findings. Communication Disorders Quarterly, 24 (1), 11-21.

Justice, L. M., Meier, J., \& Walpole, S. (2005). Learning new words from storybooks: An efficacy study with at-risk kindergartners. Language, Speech and Hearing Services in Schools, 36, 17-32.

Koppenhaver, D.A., Coleman, Kalman, \& Yoder, D.E. (1991a). The implications of emergent literacy research for children with developmental disabilities. America Journal of Speech-Language Pathology, 1, 38-44.

Koppenhaver, D.A., Evans, D.A., \& Yoder, D.E. (1991b). Childhood reading and writing experiences of literate adults with severe speech and motor impairments. Augmentative and Alternative communication, 7(1), 10-33

Koppenhaver, D.A., \& Erickson, K.A. (2003). Natural emergent literacy supports for preschoolers with autism and severe communication impairments. Topics in Language Disorders, 23(4), 283-292.

Leedy, P. D. (1989). Practical Research. Planning and design. $\left(4^{\text {th }}\right.$ Ed). New York: Macmillan Publishing Company.

Lenhart, L. \& Roskos, K. (2003). What Hannah taught Emma and why it matters. In D.M. Barone and L.M. Morrow (eds). Literacy and young children. Research-based practices (p45-60). New York: The Guilford Press. 
Light, J., \& Kelford-Smith, A. (1993). Home literacy experiences of preschoolers who use AAC systems and of their nondisabled peers. Augmentative and Alternative Communication, 9 (1), 1025.

Light, J., Binger, C., \& Kelford-Smith, A. (1994). Story reading interactions between preschoolers who use AAC and their mothers. Augmentative and Alternative Communication, 10, (4), 255-268.

Light, J., \& Kent-Walsh, J. (2003). Fostering emergent literacy for children who require AAC. The ASHA Leader, 8, 28-29. Retrieved, 13 May 2005, from http://www.asha.org/about/publications/leader-online/archives.

Loeterman, M., Paul, P.V., \& Donahue, S. (2002). Reading and deaf children. Reading Online, 5, (6), p1-18. Retrieved 3 March 2005, EJ 667659:

http://www.readingonline.org/articles/loeterman/index.html.

Makin, L. (2003). Creating positive literacy learning environments in early childhood. In N. Hall, J. Larson and J. Marsh (eds). Handbook of early childhood literacy (p326-354). London: Sage Publications.

Marschark, M. (2001). Context, cognition and deafness: planning the research agenda. In M.D. Clark, M. Marshark \& M. Karchmer (eds). Context, Cognition and Deafness. (p179-198). Washington D.C.: Gallaudet University Press.

Marschark, M., \& Lukomski, J. (2002). Understanding language and learning in deaf children. In M.D Clark, M. Marschark and M. Karchmer (eds). Context, cognition and deafness (p71-87). Washington: Gallaudet University.

McAllister, W. (2004). Philanthropy: The centre for Deaf studies - bringing hope to a linguistic minority group. Arena: Magazine for the Alumni and Friends of the University of the Witwatersrand, 11 (35), 16-18.

McGee, L.M., \& Richgels, D.J. (2000). Literacy Beginnings. Supporting young readers and writers. ( $3^{\text {rd }}$ Edition). Boston: Allyn and Bacon. 
McMillan, J.H., \& Schumacher, S. (2001). Research in education. A conceptual introduction. (5 $^{\text {th }}$ Edition). New York: Longman.

Morrow, L. M. (1993). Literacy development in the early years. Helping children read and write. $\left(2^{\text {nd }}\right.$ Ed). Boston: Allyn and Bacon.

Mouton, M., \& Marais, H.C. (1991). Basic concepts in the methodology of the social sciences (revised edition). Pretoria: Human Science Research Council Publication.

Neuman, W.L. (1997). Social Research methods. Qualitative and quantitative approaches. (3 ${ }^{\text {rd }}$ Ed). Boston: Allyn \& Bacon.

Neuman, S.B., \& Dickinson, D.K. (2001). Handbook of Early Literacy Research . New York: The Guilford Press.

Nikolajeva, M. (2003). Verbal and visual literacy: the role of picture books in the reading experiences of young children. In N. Hall, J. Larson and J. Marsh (eds.) Handbook of Early Childhood Literacy. (p234 - 245). London: Sage Publications.

Nittrouer, S., \& Burton, L.T. (2003). The role of early language experiences in the development of speech perception and language processing abilities in children with hearing loss. Volta Review, 103 (1), 5-37.

North Central Regional Educational Laboratory (1999). Pathways: Socio-economic status. http://www.ncrel.org/sdrs/areas/issues/earlycld/ea7lk.5htm. Info@ncrel.org. Retrieved 27 march 2005.

Paul, P. V. (1998). Literacy and Deafness. The development of reading, writing and literate thought. USA: Allyn and Bacon.

Paul, P. V. (2003). Processes and components of reading. In M. Marschark and P.E. Spencer (eds). Oxford handbook of deaf studies, language and education (p 97-109). Oxford: Oxford University Press. 
Pellegrini, A. D. (2002) Some theoretical and methodological considerations in studying literacy in social context. In S.B. Neuman and D.K. Dickinson (eds). Handbook of Early Literacy Research (p54-65). New York: The Guilford Press.

Rob, L. (2003). Literacy Links. Practical strategies to develop emergent literacy at-risk children need. Portsmouth: Heinemann.

Rottenberg, C.J., \& Searfoss, L. W. (1992). Becoming literate in a pre-school class: Literacy development of hearing impaired children. Journal of Reading Behaviour, XXIV (4), 463-479.

Sagstetter, M. (2004). Reading is for everyone! Compact Disc: ISAAC 4-12 October 2004, Communication for all. Natal-RN-Brazil.

Sass-Lehrer, M., \& Bodner-Johnson, B. (2003). Early intervention. Current approaches to family-centred programming. In M. Marschark and P.E. Spencer (Eds). Oxford handbook of deaf studies, language and education (p65-78). Oxford: Oxford University Press.

Schirmer, B.R., \& Williams, C.L. (2003). Approaches to teaching reading. . In M. Marschark and P.E. Spencer (Eds). Oxford handbook of deaf studies, language and education (p110-135). Oxford: Oxford University Press.

Smith, M. (2005). Literacy and Augmentative and Alternative Communication. London: Elsevier Academic Press.

Snow, C.E., Burns, M.S., \& Griffin, P (1998). Preventing reading difficulties before kindergarten. In C.E. Snow, M.S. Burns \& P. Griffin (Eds). Preventing reading difficulties in young children (chapter 5). Retrieved on 27 March 2005, from http://books.nap.edu/html/prdyc/ch5.html.

Strydom, H. (1998). The pilot Study. In: A.S. de Vos (Ed). Research at grass roots. A primer for the caring professions (p178-188). Pretoria: Van Schaik.

Swanwick, R. (2002). Sign bilingual deaf children's approaches to writing: individual strategies for bridging the gap between BSL and written English. Deafness and Education International, 4(2), 65-83. 
Swanwick, R., \& Watson, L. (2005). Literacy in the homes of young deaf children: common and distinct features of spoken language and sign bilingual environments. Journal of Early Childhood Literacy, 2005, 5 (1), pages to be advised.

Teale, W., \& Sulzby, E. (1986). Introduction: Emergent literacy as a perspective for examining how children become writers and readers. In W.H. Teale and E. Sulzby (eds). Emergent literacy. Writing and Reading (pvii-xxv). New Jersey: Ablex Publishing Corporation.

Teale, W. (1986). Home background and young children's literacy development. In W.H. Teale and E. Sulzby (eds). Emergent literacy. Writing and Reading (p173-206). New Jersey: Ablex Publishing Corporation.

Teale, W. (2003). Questions about early literacy learning and teaching that need asking - and some that don’t. In: D.M. Barone and L.M. Morrow (eds). Literacy and young children. Research-based practices (p23-44). New York: The Guilford Press.

Truax, R.R., Foo, S.F., \& Whitesell, K. (2004). Literacy learning: meeting the needs of children who are deaf or hard of hearing with additional speech needs. Volta Review, 104 (4), 307-327.

Van Kleeck, A. (1990). Emergent literacy: Learning about print before learning to read. Topics in Language Disorders, 10(2), 25-45.

Watson, L. M. (1999). Literacy and deafness: the challenge continues. Deafness and Education International, 1 (2), 96-107.

Webster, A. (2000). An international research review of literacy intervention strategies for children with severe to profound deafness. Deafness and Education International, 2 (3), 128-141.

Webster, A., \& Heinemann-Gosschalk, R. (2000). Deaf children's encounters with written texts: contrasts between hearing teachers and deaf adults in supporting reading. Deafness and Education International, 2 (1), 26-44.

Whitehurst, G.J., \& Lonigan, C.J. (1998). Child development and emergent literacy. Child Development, 69 (3), 848-872. 
Whitehurst, G.J., \& Lonigan, C.J. (2002). Emergent Literacy: Development from pre-readers to readers. In S.B. Neuman and D.K. Dickinson (eds). Handbook of Early Literacy Research (p1130). New York: The Guilford Press.

Williams, C.L. (1994). The language and literacy worlds of three profoundly deaf preschool children. Reading Research Quarterly, April, May, June 29 (2), 125-153.

Williams, C.L., \& McLean, (1997). Young deaf children's response to picture book reading in a pre-school setting. Research in the Teaching of English, 31 (3), 337-366.

Williams, C. L. (2004). Emergent literacy and deaf children. Journal of Deaf Studies and Deaf Education, 9 (4), 352-365.

Wood, L., \& Hood, E. (2004). Shared storybook readings with children who have little or no functional speech: A language intervention tool for students who use augmentative and alternative communication. Perspectives in Education, 22 (2), 101-114

Yaden, D. B., Rowe, D. W., \& MacGillivray, L. (2000). Emergent literacy: A matter (Polyphony) of perspectives. In M.L. Kamil, P.B. Mosenthal, P.D. Pearson \& R. Barr (eds). Handbook of Reading Research, Volume III (p425-454). London: Lawrence Erlbaum Associates, Publishers. 


\section{APPENDIX A}

\section{DEVELOPMENT AND DESCRIPTION OF QUESTIONNAIRE CONTENT WITH THEORETICAL JUSTIFICATION}

\begin{tabular}{|c|c|c|c|}
\hline SECTION & QUESTIONS & TOPIC & JUSTIFICATION \\
\hline $\begin{array}{l}\text { Section A: } \\
\text { Eight closed } \\
\text { questions }\end{array}$ & $\begin{array}{l}\text { Questions } \\
1-8\end{array}$ & $\begin{array}{l}\text { Background } \\
\text { information on } \\
\text { person completing } \\
\text { the questionnaire }\end{array}$ & $\begin{array}{l}\text { To obtain information on the person competing the } \\
\text { questionnaire: relationship to the child, age, home language, } \\
\text { level of qualification and employment. The North Central } \\
\text { Regional Educational Laboratory (1999) highlights that low } \\
\text { maternal education and minority language status are most } \\
\text { consistently associated with fewer signs of emergent literacy } \\
\text { and a greater number of difficulties in pre-schoolers. }\end{array}$ \\
\hline $\begin{array}{l}\text { Section B: } \\
\text { Four closed } \\
\text { questions \& } \\
\text { one } \\
\text { dichotomous } \\
\text { question }\end{array}$ & $\begin{array}{l}\text { Questions } \\
1-5\end{array}$ & $\begin{array}{l}\text { Biographical } \\
\text { information on the } \\
\text { deaf child }\end{array}$ & $\begin{array}{l}\text { To obtain information on the deaf child: age, age at diagnosis of } \\
\text { deafness, age and hearing status of other deaf siblings, mode of } \\
\text { communication used at home and type of assistive listening } \\
\text { devices used by the child. This information is important for the } \\
\text { interpretation of the results with reference to the different } \\
\text { literacy contexts. }\end{array}$ \\
\hline $\begin{array}{l}\text { Section C: } \\
\text { Thirty } \\
\text { questions in } \\
\text { total }\end{array}$ & $\begin{array}{l}\text { Questions } \\
1-11\end{array}$ & $\begin{array}{l}\text { Emergent } \\
\text { literacy contexts } \\
\text { Physical and } \\
\text { functional } \\
\text { context: reading }\end{array}$ & $\begin{array}{l}\text { The physical and functional context is important because it } \\
\text { forms the foundation of home-based literacy experiences (Light } \\
\text { and Kelford-Smith, 1993). It refers to the extent to which } \\
\text { reading materials are available in the home as well as the } \\
\text { family's reading activities. This will determine the extent to } \\
\text { which the home environment is conducive to early reading } \\
\text { experiences. }\end{array}$ \\
\hline Closed question & Question 1 & $\begin{array}{l}\text { Favourite } \\
\text { activities }\end{array}$ & $\begin{array}{l}\text { To determine whether reading and writing activities feature } \\
\text { amongst the deaf child's favourite activities as it does for AAC } \\
\text { and their nondisabled (ND) peers. Research by Light and } \\
\text { Kelford-Smith (1993) report that although these activities did } \\
\text { not occupy major portions of the day of AAC and ND children, } \\
\text { the majority of these children reported it to be a favourite } \\
\text { activity. }\end{array}$ \\
\hline $\begin{array}{l}\text { One scaled and } \\
\text { one multiple- } \\
\text { choice question } \\
\text { with request for } \\
\text { description. }\end{array}$ & $\begin{array}{l}\text { Questions } \\
2 \text { and } 3\end{array}$ & $\begin{array}{l}\text { Reading activities } \\
\text { of the family }\end{array}$ & $\begin{array}{l}\text { To determine whether reading is part of activities, which the } \\
\text { family enjoys, and what the function of reading is in the home. } \\
\text { Snow, Burns and Griffin (1998) state that children who learn } \\
\text { from their parents where literacy is a source of enjoyment may } \\
\text { be more persistent in their efforts to learn to read despite } \\
\text { difficulties they may encounter during the early years. }\end{array}$ \\
\hline Closed question & Question 4 & $\begin{array}{l}\text { Availability of } \\
\text { printed materials }\end{array}$ & $\begin{array}{l}\text { To determine which printed materials are available in the home } \\
\text { and to which extent parents are able to create a "literacy-rich } \\
\text { environment" (Morrow, 1993) for their children. Teale (1986) } \\
\text { highlight that progress in literacy is linked to the 'print culture' } \\
\text { of the home: presence of books, frequency of parents' own } \\
\text { reading and discussion of stories. }\end{array}$ \\
\hline \begin{tabular}{lr}
\multicolumn{2}{l}{ Multiple-choice } \\
question with \\
request for \\
description
\end{tabular} & Question 5 & $\begin{array}{l}\text { Deaf child's use of } \\
\text { printed material }\end{array}$ & $\begin{array}{l}\text { To determine whether the deaf child uses any of the printed } \\
\text { materials available in comparison to AAC children, who, } \\
\text { reportedly use printed material less frequently than their ND } \\
\text { peers (Light and Kelford-Smith, 1993). }\end{array}$ \\
\hline $\begin{array}{l}\text { Likert-type } \\
\text { question with } \\
\text { request for } \\
\text { description }\end{array}$ & Question 6 & $\begin{array}{l}\text { Deaf child's } \\
\text { interest in reading } \\
\text { activities }\end{array}$ & $\begin{array}{l}\text { To determine whether the deaf child shows interest in reading } \\
\text { activities and how this interest is shown. Morrow (1993) states } \\
\text { that children with an early interest in reading and writing tend to } \\
\text { spend playtime at home, writing, drawing and looking at books. }\end{array}$ \\
\hline
\end{tabular}




\begin{tabular}{|c|c|c|c|}
\hline $\begin{array}{l}\text { One } \\
\text { dichotomous } \\
\text { and one open- } \\
\text { ended questions }\end{array}$ & $\begin{array}{l}\text { Questions } \\
7 \text { and } 8\end{array}$ & $\begin{array}{l}\text { Deaf child's books } \\
\text { and favourite } \\
\text { stories }\end{array}$ & $\begin{array}{l}\text { To determine whether the deaf child owns books and what } \\
\text { his/her favourite stories are. Children who repeatedly engage in } \\
\text { literacy-related activities, independent reading and dramatic } \\
\text { play, develop "concepts about print and the alphabetic principle, } \\
\text { linguistic and phonemic awareness, the beginnings of a sight } \\
\text { vocabulary, metacognitive control and other print-based } \\
\text { understandings including the functions it may serve in their own } \\
\text { lives" (Koppenhaver and Erickson, 2003, p.284). }\end{array}$ \\
\hline $\begin{array}{l}\text { Statement- type } \\
\text { question }\end{array}$ & Question 9 & $\begin{array}{l}\text { The deaf child's } \\
\text { participation in } \\
\text { book-related } \\
\text { activities }\end{array}$ & $\begin{array}{l}\text { To determine whether the deaf child participates in other book- } \\
\text { related activities. Heineman-Gosschalk and Webster (2003) } \\
\text { acknowledge the importance of families in providing } \\
\text { opportunities for literacy activities, practice and reinforcement } \\
\text { outside the classroom situation. Such variety and activities } \\
\text { stimulate literacy interest and growth. }\end{array}$ \\
\hline $\begin{array}{l}\text { Multiple choice } \\
\text { question }\end{array}$ & Question 10 & $\begin{array}{l}\text { The deaf child's } \\
\text { preferred story } \\
\text { time. }\end{array}$ & $\begin{array}{l}\text { To determine what time of day stories are read. Robb (2003) } \\
\text { and Lenhart and Roskos (2003) refer to the affective nature and } \\
\text { emotional power of literacy encounters. During story reading at } \\
\text { bedtime, the child becomes the focus of the parent's attention, } \\
\text { portraying a strong emotional message with strong motivational } \\
\text { potential. }\end{array}$ \\
\hline $\begin{array}{l}\text { Statement-type } \\
\text { question }\end{array}$ & Question 11 & $\begin{array}{l}\text { The frequency of } \\
\text { story reading } \\
\text { activities }\end{array}$ & $\begin{array}{l}\text { To determine how often someone in the household reads to the } \\
\text { deaf child. Repeated story reading experiences are of critical } \\
\text { importance in establishing the foundations for the development } \\
\text { of reading and writing skills (Light, Binger and Kelford-Smith, } \\
\text { 1994). }\end{array}$ \\
\hline $\begin{array}{l}\text { One } \\
\text { dichotomous } \\
\text { question and } \\
\text { one multiple- } \\
\text { choice } \\
\text { question. }\end{array}$ & $\begin{array}{l}\text { Questions } \\
18 \text { and } 19\end{array}$ & $\begin{array}{l}\text { Physical and } \\
\text { functional } \\
\text { context: writing }\end{array}$ & $\begin{array}{l}\text { The physical and functional context forms the foundation to } \\
\text { home-based literacy experiences (Light and Kelford-Smith, } \\
\text { 1993). It refers to the extent to which writing materials are } \\
\text { available in the home as well as the family's writing activities. } \\
\text { This will give and indication of the extent to which the home } \\
\text { environment is conducive to early writing experiences. } \\
\text { To determine whether the family enjoys writing activities, the } \\
\text { frequency of writing activities and the function of writing } \\
\text { material. Morrow (1993, p.17) points out that young children } \\
\text { have a natural interest in writing activities and that they "model } \\
\text { adult writing behaviours and their scribbles, drawings, random } \\
\text { letters and invented spellings are earl forms of writing". }\end{array}$ \\
\hline Closed question & Que: & $\begin{array}{l}\text { Availability of } \\
\text { writing materials }\end{array}$ & $\begin{array}{l}\text { To determine what kind of writing materials are available to the } \\
\text { deaf child. Lenhart and Roskos (2003) state that when literacy } \\
\text { materials are readily available in the environment, they } \\
\text { stimulate literacy activity so that children naturally explore and } \\
\text { interact with them. In this way the foundation for literacy } \\
\text { knowledge is formed. }\end{array}$ \\
\hline $\begin{array}{l}\text { Multiple-choice } \\
\text { question }\end{array}$ & Question 21 & $\begin{array}{l}\text { Deaf child's } \\
\text { participation in } \\
\text { writing activities }\end{array}$ & $\begin{array}{l}\text { To determine how often the deaf child uses the writing materials } \\
\text { that are available. According to Lenhart and Roskos (2003, } \\
\text { p.98), children "engage in literacy activities they engender, just } \\
\text { as they might pick up a toy and act on its potential". }\end{array}$ \\
\hline \begin{tabular}{l}
\multicolumn{2}{l}{ Likert-type } \\
question with \\
request for \\
description
\end{tabular} & Question 22 & $\begin{array}{l}\text { Deaf child's } \\
\text { interest in writing } \\
\text { activities }\end{array}$ & $\begin{array}{l}\text { To determine whether the deaf child is interested in writing } \\
\text { activities and how this interest is shown. If the child is part of a } \\
\text { family context where reading and writing materials can be } \\
\text { freely selected and used, the child is more likely to be actively } \\
\text { involved in these activities and to use adults as role-models } \\
\text { (Morrow, 1993). }\end{array}$ \\
\hline
\end{tabular}




\begin{tabular}{|c|c|c|c|}
\hline Closed question & $\begin{array}{l}\text { Questions } \\
12-17 \\
\text { Questions } \\
23-25\end{array}$ & $\begin{array}{l}\text { Types of books } \\
\text { read }\end{array}$ & $\begin{array}{l}\text { Language context solicits information regarding the social } \\
\text { interaction surrounding literacy events (Light and Kelford- } \\
\text { Smith, 1993). This includes interpersonal interaction between } \\
\text { the deaf child and other members of the family. } \\
\text { To determine the type of books parents read to their deaf child. } \\
\text { According to Robb (2003), when children listen and interact } \\
\text { with many different books, they come to understand the } \\
\text { structure of narrative non-fiction and poetry, thereby building } \\
\text { knowledge of different genres. }\end{array}$ \\
\hline Closed question & Question 13 & $\begin{array}{l}\text { Deaf child's role } \\
\text { in story reading } \\
\text { activities }\end{array}$ & $\begin{array}{l}\text { To determine how the deaf child participates in story reading } \\
\text { activities. This will be contrasted with the parents' role during } \\
\text { storybook interactions. According to Gillespie and Twardosz } \\
\text { (1997, p.329), "readers employed in interactive and expressive } \\
\text { reading styles, were more engaged" and participative than when } \\
\text { reading was unexpressive. }\end{array}$ \\
\hline $\begin{array}{l}\text { Closed } \\
\text { question }\end{array}$ & Question 14 & $\begin{array}{l}\text { Deaf child's } \\
\text { communication } \\
\text { during story } \\
\text { reading }\end{array}$ & $\begin{array}{l}\text { To determine how the deaf child communicates with the story } \\
\text { reader during a story reading session. This question will be } \\
\text { interpreted in combination with question } 16 \text { as the child's role } \\
\text { in story reading is also related to how the child communicates } \\
\text { during story reading sessions. }\end{array}$ \\
\hline $\begin{array}{l}\text { Closed } \\
\text { question }\end{array}$ & Question 15 & $\begin{array}{l}\text { Positioning during } \\
\text { story reading }\end{array}$ & $\begin{array}{l}\text { To determine how parents position their deaf child during story } \\
\text { reading activities. Positioning during reading activities is } \\
\text { important to ensure eye contact and visual continuity during the } \\
\text { reading activity. Heineman-Gosschalk and Webster (2003) } \\
\text { emphasise that deaf children rely on their visual channel for } \\
\text { communication and thus need to shift their attention between } \\
\text { the book and the adult. }\end{array}$ \\
\hline $\begin{array}{l}\text { Closed } \\
\text { question }\end{array}$ & Question 16 & $\begin{array}{l}\text { Parents' role in } \\
\text { story reading } \\
\text { activities }\end{array}$ & $\begin{array}{l}\text { To determine how the parents read to their deaf child. } \\
\text { Swanwick and Watson (2005) highlight the difficulties parents } \\
\text { experience when reading to their deaf child, suggesting that } \\
\text { parents tend to control the interaction sequence when they read } \\
\text { with their deaf children. }\end{array}$ \\
\hline $\begin{array}{l}\text { Dichotomous } \\
\text { question }\end{array}$ & Question 17 & $\begin{array}{l}\text { Deaf child's } \\
\text { enjoyment of } \\
\text { reading }\end{array}$ & $\begin{array}{l}\text { To determine whether the deaf child enjoys participating in } \\
\text { reading activities with other members of the family. Truax et al } \\
\text { (2004) state that as children become personally engaged in the } \\
\text { literacy process, they assume responsibility for choosing books } \\
\text { and activities to meet social and personal purposes. This can } \\
\text { only happen if the child experiences enjoyment from literacy- } \\
\text { related activities. }\end{array}$ \\
\hline $\begin{array}{l}\text { One } \\
\text { dichotomous } \\
\text { question and } \\
\text { one closed } \\
\text { question }\end{array}$ & $\begin{array}{l}\text { Questions } \\
23 \text { and } 24\end{array}$ & $\begin{array}{l}\text { Family's } \\
\text { participation in } \\
\text { writing and } \\
\text { drawing activities }\end{array}$ & $\begin{array}{l}\text { To determine the family's participation in the deaf child's } \\
\text { literacy activities. Webster and Heineman-Gosschalk (2000) } \\
\text { state that literacy environments, where interactions are } \\
\text { specifically constructed around text, shape a child's reading } \\
\text { experiences. }\end{array}$ \\
\hline $\begin{array}{l}\text { One closed } \\
\text { question }\end{array}$ & Question 25 & $\begin{array}{l}\text { Siblings' } \\
\text { participation in the } \\
\text { deaf child's } \\
\text { reading and } \\
\text { writing activities } \\
\text { at home }\end{array}$ & $\begin{array}{l}\text { To determine whether older siblings interact in literacy related } \\
\text { activities with the deaf child and what the nature of these } \\
\text { interaction are. Lenhart and Ross (2003, p.91) state that older } \\
\text { siblings can share their knowledge of literacy "in ways that are } \\
\text { instructive, sensitive and enjoyable”. }\end{array}$ \\
\hline
\end{tabular}




\begin{tabular}{|c|c|c|c|}
\hline $\begin{array}{l}\text { Likert-type } \\
\text { question with } \\
\text { request for } \\
\text { explanation }\end{array}$ & $\begin{array}{l}\text { Questions } \\
\text { 26-27 }\end{array}$ & $\begin{array}{l}\text { Parental priorities } \\
\text { regarding the deaf } \\
\text { child's } \\
\text { development }\end{array}$ & $\begin{array}{l}\text { The Emotional context focuses on the value and priority } \\
\text { accorded to literacy events and the responsibility assumed by } \\
\text { families in this regard (Light and Kelford-Smith, 1993). This } \\
\text { context refers to the emotional and motivational climate relating } \\
\text { to literacy development (Leichter } 1984 \text { in Morrow, 1993). } \\
\text { To determine the parents' priorities as related to the acquisition } \\
\text { of literacy skills. Research by Schleper (1995 in Swanwick and } \\
\text { Watson, 2005) indicates that successful parent-child book } \\
\text { sharing takes place in positive, supportive environments where } \\
\text { parents expect their deaf children to become literate. }\end{array}$ \\
\hline $\begin{array}{l}\text { Likert-type } \\
\text { question }\end{array}$ & Question 27 & $\begin{array}{l}\text { Parental } \\
\text { responsibilities }\end{array}$ & $\begin{array}{l}\text { To determine if parents are aware of their responsibility in } \\
\text { providing early literacy experiences to their deaf child. Robb } \\
\text { (2003) quotes research indicating that success in reading and } \\
\text { writing at school depends on children's home literacy } \\
\text { experiences, which includes the number of stories parents read } \\
\text { aloud, the amount of oral story telling and the meaningful } \\
\text { conversations between parent and child. }\end{array}$ \\
\hline $\begin{array}{l}\text { Statement } \\
\text { question }\end{array}$ & $\begin{array}{l}\text { Questions } \\
28-29\end{array}$ & $\begin{array}{l}\text { Parental } \\
\text { experiences in } \\
\text { reading to their } \\
\text { deaf child }\end{array}$ & $\begin{array}{l}\text { Gaskins (2003, p.45) refers to "productive home school-based } \\
\text { communication and collaboration" for the acquisition of literacy } \\
\text { skills in children. This context highlights parental need for } \\
\text { guidance in providing literacy experiences and the support } \\
\text { available to them. } \\
\text { To determine whether hearing parents experience specific } \\
\text { problems during literacy-related activities with their deaf } \\
\text { children. Heineman-Gosschalk and Webster (2003) anticipate } \\
\text { that hearing parents of deaf children may have unique problems } \\
\text { in supporting reading which may relate to sustaining visual } \\
\text { attention and shifting of attention between the book and the } \\
\text { adult. }\end{array}$ \\
\hline $\begin{array}{l}\text { Statement } \\
\text { question }\end{array}$ & Question 29 & $\begin{array}{l}\text { Literacy related } \\
\text { services and } \\
\text { advice received by } \\
\text { parents }\end{array}$ & $\begin{array}{l}\text { To determine the nature of support services parents have } \\
\text { experienced or have had access to in providing home-based } \\
\text { literacy experiences to their deaf children. Heineman-Gosschalk } \\
\text { and Webster (2003) highlight the importance of continuity } \\
\text { between home and school. }\end{array}$ \\
\hline $\begin{array}{l}\text { Open ended } \\
\text { question }\end{array}$ & Question 30 & $\begin{array}{l}\text { General } \\
\text { Additional } \\
\text { comments and } \\
\text { observations } \\
\text { parents wish to } \\
\text { present }\end{array}$ & $\begin{array}{l}\text { To provide parents the opportunity to share their own concerns, } \\
\text { observations and experiences. }\end{array}$ \\
\hline
\end{tabular}

Adapted from Light and Kelford-Smith (1993) and Heinemann-Gosschalk and Webster (2003). 


\section{APPENDIX B \\ RESULTS OF PILOT STUDY PHASE ONE. \\ ADJUSTMENTS TO THE QUESTION FORMAT, QUESTION \\ FORMULATION AND RESPONSE FORMAT}

Please read this in conjunction with Table 3.2

\begin{tabular}{|c|c|c|}
\hline $\begin{array}{l}\text { Section/question: } \\
\text { Pilot Study Phase } 1\end{array}$ & $\begin{array}{l}\text { Previous question format and } \\
\text { question formulation }\end{array}$ & $\begin{array}{l}\text { Adjusted question format, question } \\
\text { formulation and response format used } \\
\text { for Pilot Study Phase } 2\end{array}$ \\
\hline A: Q3 & $\begin{array}{l}\text { What is your level of qualification? } \\
\text { - } \quad \text { Matric } \\
\text { - } \text { Post-Matric } \\
\text { - } \quad \text { Praduate } \\
\text { Post-graduate. }\end{array}$ & $\begin{array}{l}\text { Now Q4: What is your highest educational } \\
\text { qualification? } \\
\text { - Less than } 10 \text { years at school } \\
\text { - } 10-12 \text { years at school } \\
\text { - } 2-3 \text { years after school } \\
\text { - } 4 \text { or more years after school }\end{array}$ \\
\hline A: Q4 & $\begin{array}{l}\text { Open-ended question: If you are } \\
\text { currently employed, what is your } \\
\text { occupation? }\end{array}$ & $\begin{array}{l}\text { Closed question now Q5: What is your } \\
\text { current employment status? } \\
\text { - Unemployed } \\
\text { - Home Executive } \\
\text { - } \text { Part-time employment } \\
\text { - } \text { Full-time employment }\end{array}$ \\
\hline A: Q5 & $\begin{array}{l}\text { Open-ended question: What hours do } \\
\text { you work? }\end{array}$ & $\begin{array}{l}\text { As this question does not provide necessary } \\
\text { information it was omitted and reformulated } \\
\text { into two questions concerning employment } \\
\text { of the parents. Closed question now Q5: as } \\
\text { above } \\
\text { Closed question Q6: What is your spouse's } \\
\text { current employment status? } \\
\text { - Unemployed } \\
\text { - Home Executive } \\
\text { - Part-time employment } \\
\text { - Full- time employment }\end{array}$ \\
\hline A: Q7 & $\begin{array}{l}\text { Open-ended question. } \\
\text { What is your home language? }\end{array}$ & $\begin{array}{l}\text { Closed question. } \\
\text { What is your home language? } \\
\text { - Afrikaans } \\
\text { - English } \\
\text { - Sotho } \\
\text { - Zulu } \\
\text { - Xhosa } \\
\text { Other, specify }\end{array}$ \\
\hline A: Q8 & $\begin{array}{l}\text { Open-ended question. } \\
\text { Which other languages are spoken in } \\
\text { your home? }\end{array}$ & $\begin{array}{l}\text { Closed question. } \\
\text { Which other languages are spoken in your } \\
\text { home? } \\
\text { - Afrikaans } \\
\text { - } \text { English } \\
\text { - Zotho } \\
\text { - Xhlu } \\
\text { - Sign Language } \\
\text { - Other, specify }\end{array}$ \\
\hline
\end{tabular}




\begin{tabular}{|c|c|c|}
\hline B: Q1 & $\begin{array}{l}\text { Open-ended question: What is the age } \\
\text { and date of birth of your deaf child? }\end{array}$ & 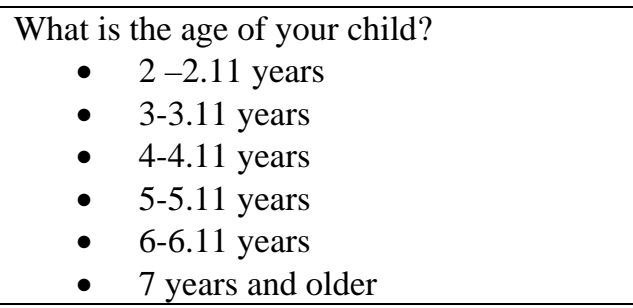 \\
\hline B: Q2 & $\begin{array}{l}\text { Open-ended question. } \\
\text { Does this child have other siblings? } \\
\text { Please indicate the ages and hearing } \\
\text { status of the other siblings in your } \\
\text { household. }\end{array}$ & $\begin{array}{l}\text { Matrix-type question. } \\
\text { Tabulated format to indicated the gender, } \\
\text { age and hearing status of other siblings. }\end{array}$ \\
\hline B: Q3 & $\begin{array}{l}\text { Open-ended question. } \\
\text { At what age was your child's deafness } \\
\text { diagnosed? }\end{array}$ & $\begin{array}{l}\text { Closed question. } \\
\text { At what age was your child's deafness } \\
\text { diagnosed? } \\
\begin{array}{ll}\text { - } & 0-12 \text { months } \\
\text { - } & 13-24 \text { months } \\
\text { - } & 25-36 \text { months } \\
\text { - } & \text { After } 3 \text { years }\end{array}\end{array}$ \\
\hline B: Q4 & $\begin{array}{l}\text { Please indicate how you communicate } \\
\text { with your deaf child. } \\
\text { - Speech only } \\
\text { - Sign Language } \\
\text { - A combination of Speech and } \\
\text { Sign }\end{array}$ & $\begin{array}{l}\text { Please indicate how you communicate with } \\
\text { your child. } \\
\text { - } \quad \text { Speech only } \\
\text { - } \quad \text { Sign Language only } \\
\text { - } \quad \text { Speech and Sign } \\
\text { - } \quad \text { Speech and natural gestures } \\
\text { - } \quad \text { Speech, Sign and natural gestures }\end{array}$ \\
\hline B: Q5 & $\begin{array}{lll}\text { Please } & \text { indicate your child's } \\
\text { amplification system. } & \\
\text { - } & \text { Hearing Aids } \\
\text { - } & \text { Cochlear Implant } \\
\text { - } & \text { Added FM System }\end{array}$ & $\begin{array}{l}\text { Please indicate which of the following } \\
\text { assistive listening devices your child uses. } \\
\text { (Please cross all relevant boxes). } \\
\text { - Hearing Aids } \\
\text { - Cochlear Implant } \\
\text { - FM System } \\
\text { - None of the above }\end{array}$ \\
\hline C: Q1 & $\begin{array}{l}\text { The question on daily activities and } \\
\text { time spent on these activities during } \\
\text { weekdays and over weekends was } \\
\text { confusing and difficult to complete. }\end{array}$ & This question was omitted. \\
\hline C: Q3 \& Q8 & $\begin{array}{l}\text { These questions initially required a } \\
\text { yes/no response only. }\end{array}$ & $\begin{array}{l}\text { Closed question (now Q2 and Q6) } \\
\text { The response format for both these } \\
\text { questions was changed to a closed format } \\
\text { utilising a four-point scale. Respondents are } \\
\text { requested to cross only one block. } \\
\text { - Not at all interested } \\
\text { - Somewhat interested } \\
\text { - Mostly interested } \\
\text { - Very interested }\end{array}$ \\
\hline C: Q4, Q7, Q21 \& Q24 & $\begin{array}{l}\text { Questions relating to the family's } \\
\text { reading and writing activities were } \\
\text { changed from a four-point to a five- } \\
\text { point scale. } \\
\text { - Seldom } \\
\text { - } \quad \text { Once a day } \\
\text { - } \quad \text { Many times a day } \\
\text { - } 2-3 \text { times per week }\end{array}$ & $\begin{array}{l}\text { Closed questions (now Q3, Q5, Q19 \& } \\
\text { Q21). The five-point scale used was as } \\
\text { follows: } \\
\text { - Never } \\
\text { - } 2-3 \text { times per week } \\
\text { - Many times a day } \\
\text { - Once a day } \\
\text { - Other, please specify }\end{array}$ \\
\hline
\end{tabular}




\begin{tabular}{|c|c|c|}
\hline C: Q11 & $\begin{array}{l}\text { Does your child participate in any of } \\
\text { the following activities? If so, please } \\
\text { indicate how often he/she participates } \\
\text { in each activity. Categories used: } \\
\text { - Daily } \\
\text { - Weekly } \\
\text { - Monthly }\end{array}$ & $\begin{array}{l}\text { Now Q9. Please indicate how often your } \\
\text { child participates in each of the following } \\
\text { activities. Please respond to all the } \\
\text { statements, by crossing the relevant boxes. } \\
\text { - Never } \\
\text { - Hardly ever } \\
\text { - Daily } \\
\text { - Weekly } \\
\text { - Monthly }\end{array}$ \\
\hline C: Q12 & $\begin{array}{l}\text { How often do you or someone else in } \\
\text { your household read to your child? } \\
\text { (Tick only one). }\end{array}$ & $\begin{array}{l}\text { Absorbed into Q11 as part of the reading } \\
\text { activities. }\end{array}$ \\
\hline C: Q14 & $\begin{array}{l}\text { Please indicate how much time per } \\
\text { week your deaf child engages in } \\
\text { reading activities or looking at books. } \\
\text { Categories used: } \\
\text { - Hardly ever } \\
\text { - Less than } 1 \text { hour per week } \\
\text { - } 1-3 \text { hours per week } \\
\text { - More than } 3 \text { hour per week }\end{array}$ & $\begin{array}{l}\text { Now Q11. Please indicate how much time } \\
\text { per week your child engages in reading } \\
\text { activities or looking at books. Please } \\
\text { respond to all the statements by crossing the } \\
\text { relevant boxes. } \\
\text { - Never } \\
\text { - Hardly ever } \\
\text { - Less than } 1 \text { hour per week } \\
\text { - } 1 \text {-3 hours per week } \\
\text { - } \quad \text { More than } 3 \text { hour per week }\end{array}$ \\
\hline C: Q16 & $\begin{array}{l}\text { Closed question with } 8 \text { response } \\
\text { options }\end{array}$ & $\begin{array}{l}\text { Now Q13. Closed question with the } \\
\text { following response options added: } \\
\text { - Looks around with little interest } \\
\text { - } \quad \text { Grabs the book away } \\
\text { - } \quad \text { Tries to tear the pages }\end{array}$ \\
\hline C: Q19 & $\begin{array}{l}\text { When you read a book with your child, } \\
\text { what do you usually do? }\end{array}$ & $\begin{array}{l}\text { Now Q16. When you read a book with your } \\
\text { child, what do you usually do? (Please cross } \\
\text { all the relevant blocks). The following } \\
\text { response options were added: } \\
\text { - Point to the picture and tell the } \\
\text { story } \\
\text { - Ask your child what will happen } \\
\text { next }\end{array}$ \\
\hline General & $\begin{array}{l}\text { Inclusion of the phrase "your deaf } \\
\text { child" }\end{array}$ & $\begin{array}{l}\text { Some respondents found the repetition of } \\
\text { this phrase in each question, offensive. The } \\
\text { repetition of the phrase was therefore } \\
\text { omitted. An instruction in the covering } \\
\text { letter reminded respondents to answer all } \\
\text { questions with reference to their deaf child. }\end{array}$ \\
\hline
\end{tabular}




\section{APPENDIX C \\ RESULTS OF PILOT STUDY PHASE TWO \\ ADJUSTMENTS TO THE QUESTIONNAIRE FOLLOWING THE TRANSLATION INTO AFRIKAANS}

Please read this in conjunction with Table 3.4

\begin{tabular}{|c|c|c|c|}
\hline $\begin{array}{l}\text { Section A, B } \\
\text { or C and } \\
\text { question (Q) }\end{array}$ & $\begin{array}{l}\text { Reason for } \\
\text { adjustment }\end{array}$ & Adjustment needed & Adjustment made \\
\hline A: Q 5 and 6 & $\begin{array}{l}\text { Discrepancy in } \\
\text { translation of a } \\
\text { word }\end{array}$ & Afrikaans "tuisteskepper" & $\begin{array}{l}\text { Changed in English from "home executive" } \\
\text { to more colloquial "home maker". }\end{array}$ \\
\hline A: Q8 & $\begin{array}{l}\text { Discrepancy in } \\
\text { wording of the } \\
\text { question }\end{array}$ & $\begin{array}{l}\text { Sign Language is used and not } \\
\text { spoken. This discrepancy } \\
\text { became clear through the } \\
\text { translation into Afrikaans. }\end{array}$ & $\begin{array}{l}\text { The English question was re-worded for } \\
\text { accuracy and equality in translation to: } \\
\text { "Which other languages are used in your } \\
\text { home?" }\end{array}$ \\
\hline B: Q2 & $\begin{array}{l}\text { Discrepancy in } \\
\text { wording of the } \\
\text { question }\end{array}$ & $\begin{array}{l}\text { The English version refers to } \\
\text { "other children in the } \\
\text { household". This was omitted in } \\
\text { the Afrikaans version. }\end{array}$ & $\begin{array}{l}\text { Reference to "ander kinders in u } \\
\text { huishouding" was added to the formulated } \\
\text { question. }\end{array}$ \\
\hline B: Q3 & $\begin{array}{l}\text { Discrepancy in } \\
\text { translation of a } \\
\text { phrase }\end{array}$ & $\begin{array}{l}\text { In Afrikaans, } \\
\text { "klankversterkingsisteme" was } \\
\text { the best translation for "assistive } \\
\text { listening devices" }\end{array}$ & $\begin{array}{l}\text { For equality in translation it was decided to } \\
\text { change the English to "sound } \\
\text { amplification systems". }\end{array}$ \\
\hline $\begin{array}{l}\text { B: Q3 English } \\
\text { and Afrikaans } \\
\text { version }\end{array}$ & $\begin{array}{l}\text { For clarity in } \\
\text { response } \\
\text { requirements in } \\
\text { both } \\
\text { questionnaires }\end{array}$ & $\begin{array}{l}\text { This is a closed question where } \\
\text { it was unclear whether one or } \\
\text { more options could be crossed }\end{array}$ & $\begin{array}{l}\text { English: Please cross all relevant blocks } \\
\text { Afrikaans: Maak asb. kruisies in al die } \\
\text { toepaslike blokkies. } \\
\text { These instructions were used consistently } \\
\text { throughout the questionnaire. }\end{array}$ \\
\hline C: Q3 & $\begin{array}{l}\text { Discrepancy in } \\
\text { translation of a } \\
\text { word }\end{array}$ & $\begin{array}{l}\text { The Afrikaans, "werksverwante } \\
\text { leesstof" was the best translation } \\
\text { for "work related reading } \\
\text { material”. }\end{array}$ & $\begin{array}{l}\text { For equality in translation it was decided to } \\
\text { change the English to "work related } \\
\text { reading matter". }\end{array}$ \\
\hline C: Q4 & $\begin{array}{l}\text { Discrepancy in } \\
\text { the translation of } \\
\text { a phrase }\end{array}$ & $\begin{array}{l}\text { Through the translation into } \\
\text { Afrikaans it became clear that } \\
\text { the English version needed } \\
\text { greater clarity. }\end{array}$ & $\begin{array}{l}\text { For greater clarity the English question was } \\
\text { re-worded to "Which of the following } \\
\text { printed materials are readily available in } \\
\text { your home?" The Afrikaans is an exact } \\
\text { translation of this sentence. }\end{array}$ \\
\hline
\end{tabular}




\begin{tabular}{|c|c|c|c|}
\hline $\begin{array}{l}\text { Section } A, B \\
\text { or } C \text { and } \\
\text { question }(Q)\end{array}$ & $\begin{array}{l}\text { Reason for } \\
\text { adjustment }\end{array}$ & Adjustment needed & Adjustment made \\
\hline C: Q5 & $\begin{array}{l}\text { For clarity in } \\
\text { question } \\
\text { formulation in both } \\
\text { questionnaires }\end{array}$ & $\begin{array}{l}\text { Through the translation } \\
\text { process, it became clear that } \\
\text { reference to "the above } \\
\text { mentioned" were needed. } \\
\text { This was necessary for clarity } \\
\text { in question formulation in } \\
\text { both questionnaires. }\end{array}$ & $\begin{array}{l}\text { English: "How often does your child make use } \\
\text { of the above mentioned printed material?” } \\
\text { Afrikaans: "Hoe dikwels gebruik u kind enige } \\
\text { van die bogenoemde gedrukte media?” }\end{array}$ \\
\hline C: Q9 \& Q11 & $\begin{array}{l}\text { Discrepancy in } \\
\text { wording of the } \\
\text { question and clarity } \\
\text { in response } \\
\text { requirements }\end{array}$ & $\begin{array}{l}\text { Through translation it became } \\
\text { clear that clarity in question } \\
\text { formulation was needed in } \\
\text { both versions of the } \\
\text { questionnaire. }\end{array}$ & $\begin{array}{l}\text { English: "Please respond to all the statements, } \\
\text { by crossing the relevant boxes." } \\
\text { Afrikaans:” Antwoord asb. op al die stellings } \\
\text { deur kruisies in die toepaslike blokkies te } \\
\text { maak." }\end{array}$ \\
\hline C: Q12 & $\begin{array}{l}\text { Discrepancy in } \\
\text { wording of the } \\
\text { question }\end{array}$ & $\begin{array}{l}\text { The Afrikaans translation } \\
\text { makes use of the word } \\
\text { "gewoonlik" which adds } \\
\text { clarity to the question. }\end{array}$ & $\begin{array}{l}\text { The English question was re-worded as "When } \\
\text { you or someone in your household reads to your } \\
\text { child, what type of books do you usually read?" }\end{array}$ \\
\hline C: Q13 & $\begin{array}{l}\text { Discrepancy in } \\
\text { translation of a } \\
\text { word }\end{array}$ & $\begin{array}{l}\text { Afrikaans version uses } \\
\text { "aandagtig" as a translation } \\
\text { for "quietly". It was felt that } \\
\text { this word better meets the } \\
\text { requirement of the question. }\end{array}$ & $\begin{array}{l}\text { The English version was changed from "listens } \\
\text { quietly" to "listens attentively". }\end{array}$ \\
\hline C: Q20 & $\begin{array}{l}\text { Discrepancy in } \\
\text { wording of the } \\
\text { question }\end{array}$ & $\begin{array}{l}\text { The English version refers to } \\
\text { writing and drawing materials } \\
\text { that are readily available. This } \\
\text { was omitted in the translation. }\end{array}$ & $\begin{array}{l}\text { The Afrikaans version was change to include the } \\
\text { word "geredelik beskikbaar" to ensure equality } \\
\text { in translation. }\end{array}$ \\
\hline C: Q21 & $\begin{array}{l}\text { For clarity in } \\
\text { question } \\
\text { formulation in both } \\
\text { questionnaires }\end{array}$ & $\begin{array}{l}\text { Through the translation } \\
\text { process, it became clear that } \\
\text { reference to "the above } \\
\text { mentioned" was needed. This } \\
\text { was necessary for clarity in } \\
\text { question formulation in both } \\
\text { questionnaires. }\end{array}$ & $\begin{array}{l}\text { English: "How often does your child make use } \\
\text { of the above mentioned writing and drawing } \\
\text { materials?" } \\
\text { Afrikaans: "Hoe dikwels gebruik u kind enige } \\
\text { van die bogenoemde skryf- en tekenmateriaal?" }\end{array}$ \\
\hline C: Q26 & $\begin{array}{l}\text { Discrepancy in } \\
\text { wording of the } \\
\text { question }\end{array}$ & $\begin{array}{l}\text { The English "at this point in } \\
\text { time” was translated as } \\
\text { "huidiglik" in Afrikaans. For } \\
\text { greater equality in translation } \\
\text { the English version was } \\
\text { adjusted. }\end{array}$ & $\begin{array}{l}\text { The English "at this point in time" was change } \\
\text { to "presently". }\end{array}$ \\
\hline C: Q28 & $\begin{array}{l}\text { Discrepancy in } \\
\text { translation of a } \\
\text { word }\end{array}$ & $\begin{array}{l}\text { The English "lack of } \\
\text { confidence" was incorrectly } \\
\text { translated as "geen vertroue } \\
\text { nie". }\end{array}$ & $\begin{array}{l}\text { The Afrikaans version was change to "het nie } \\
\text { genoeg selfvertroue" for equality in translation. }\end{array}$ \\
\hline
\end{tabular}




\section{APPENDIX D \\ QUESTIONNAIRE}

\section{Section A:}

\section{Background information on person completing the questionnaire}

1. What is your relationship to the deaf child?

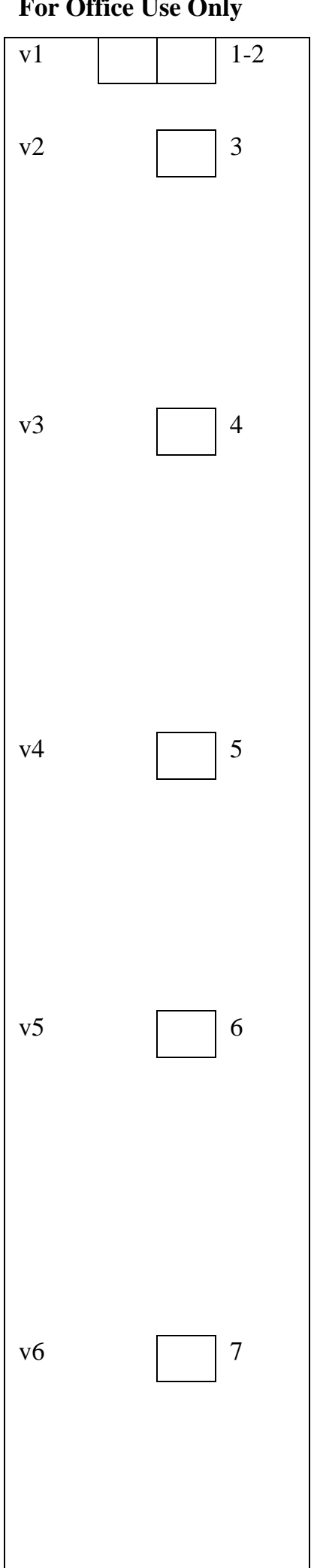

2. What is your age?

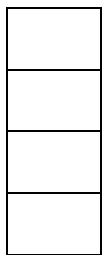

20-30 years

$31-40$ years

$41-50$ years

51 years and older

3. What is your marital status?

\begin{tabular}{|l|l}
\hline & Single, never married \\
Married \\
Divorced
\end{tabular}

4. What is your highest educational qualification?

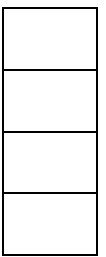

Less than 10 years at school

10-12 years at school

2-3 years after school

4 or more years after school

5. What is your current employment status?

\begin{tabular}{|l|l}
\hline & Unemployed \\
Homemaker \\
\cline { 1 - 1 } Part time employment \\
\cline { 1 - 1 } Full time employment
\end{tabular}


6. What is your spouse's current employment status?

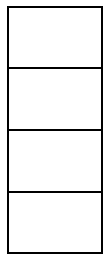

Unemployed

Homemaker

Part time employment

Full time employment

7. What is your home language?

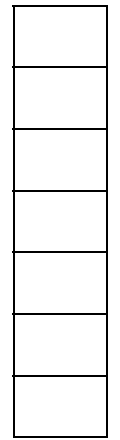

Afrikaans

English

Sotho

Zulu

Xhosa

Sign Language

Other, specify:

8. Which other languages are used in your home?

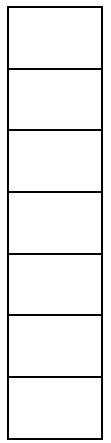

Afrikaans

English

Sotho

Zulu

Xhosa

Sign Language

Other, specify:

\section{Section B:}

\section{Background information on your deaf child}

1. What is the age of your child?

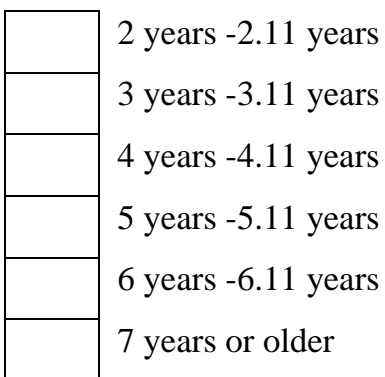


2. Does your child have siblings?

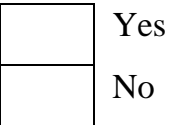

If yes, please state the ages and hearing status of the other children in your household.

\begin{tabular}{|c|c|c|c|l|}
\hline \multicolumn{2}{|l|}{ Sibling } & \multicolumn{2}{l|}{ Hearing status } & \multicolumn{1}{l}{} \\
\hline Brother & Sister & Deaf & Hearing & Age \\
\hline & & & & \\
\hline & & & & \\
\hline & & & & \\
\hline
\end{tabular}

3. At what age was your child's deafness diagnosed?

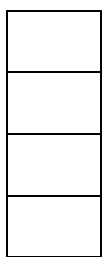

0-12 months

$13-24$ months

25 - 36 months

After 3 years

4. Please indicate how you communicate with your child.

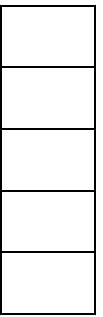

Speech only

Sign Language only

Speech and Sign

Speech and natural gestures

Speech, Sign Language and natural gestures

5. Please indicate which of the following sound amplification systems your child uses. (Please cross all the relevant blocks).

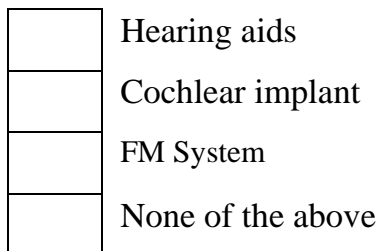




\section{Section C:}

\section{Information on your deaf child's activities}

1. What are your child's favourite activities? (Please cross all the relevant blocks).

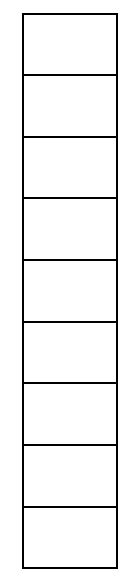

Looking at books

Reading with an adult

Watching TV

Drawing alone

Drawing with other family members

Playing outside

Playing inside

Sporting Activities

Other, specify

2. How interested are you or others in your family in reading activities? (Please cross only one block).

\begin{tabular}{|l|l}
\hline & $\begin{array}{l}\text { Not at all interested } \\
\text { Somewhat interested }\end{array}$ \\
\cline { 1 - 1 } Mostly interested \\
Very interested
\end{tabular}

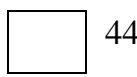

3. How often do you or others in your family read at home in the presence of your deaf child? (Please cross only one block).

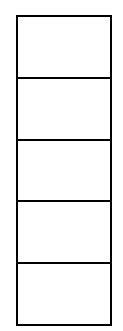

Never

2-3 times per week

Many times a day

Once a day

Other, specify

Please describe these reading activities (e.g. mom reads novels, recipes, work-related reading

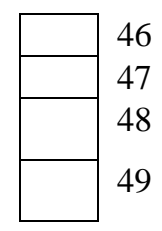


4. Which of the following printed materials are readily available in your home? (Please cross all the relevant blocks).

\begin{tabular}{|l|l}
\hline & Magazines \\
Novels \\
Non fiction books \\
Coffee table books \\
Recipe Books \\
TV Guides \\
Newspapers \\
Catalogues \\
Letters / e-mail \\
Children's story books \\
Children's magazines \\
Children's picture books \\
\cline { 1 - 1 } Other:
\end{tabular}

\begin{tabular}{|l|l|l|} 
v43 & 50 \\
v44 & 51 \\
v45 & 52 \\
v46 & 53 \\
v47 & 53 \\
v48 & 54 \\
v49 & 55 \\
v50 & 56 \\
v51 & 57 \\
v52 & 58 \\
v53 & 59 \\
v54 & 60 \\
v5 & 51 \\
v55 & 62
\end{tabular}

5. How often does your child make use of the above-mentioned printed material? (Please cross only one block).

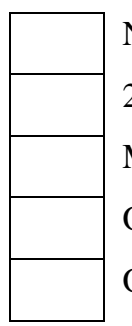

Never

2-3 times per week

Many times a day

Once a day

Other, specify

What is your child's favourite printed material? (Please be specific).

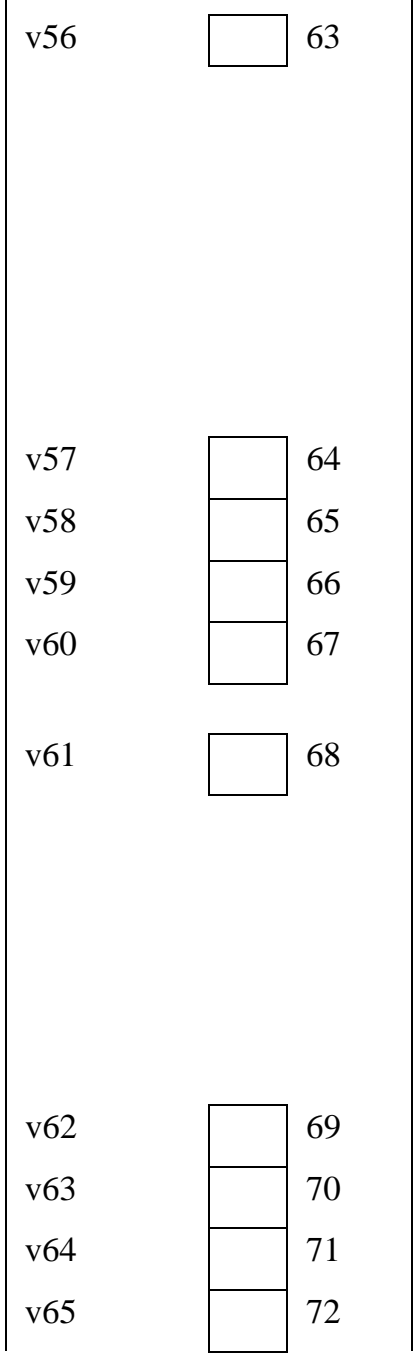

6. Is your child interested in reading activities? (Please cross only one block).

\begin{tabular}{|l|l}
\hline & Not at all interested \\
Somewhat interested \\
Mostly interested \\
Very interested
\end{tabular}

How does he/she show interest in reading activities? 
7. Does your child own any books?

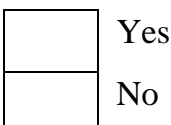

If so, approximately how many books?

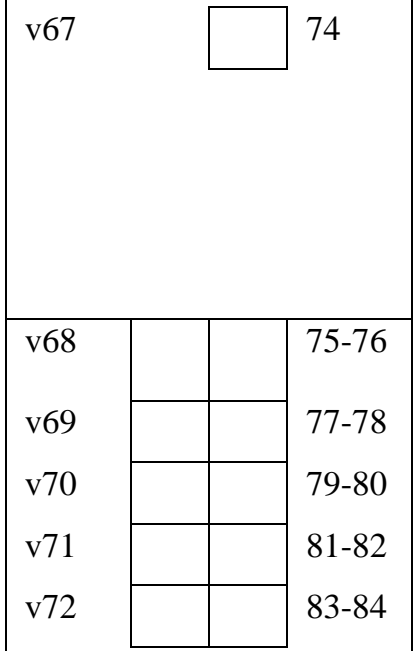

9. Please indicate how often your child participates in each of the following activities. Please respond to all the statements, by crossing the relevant boxes.

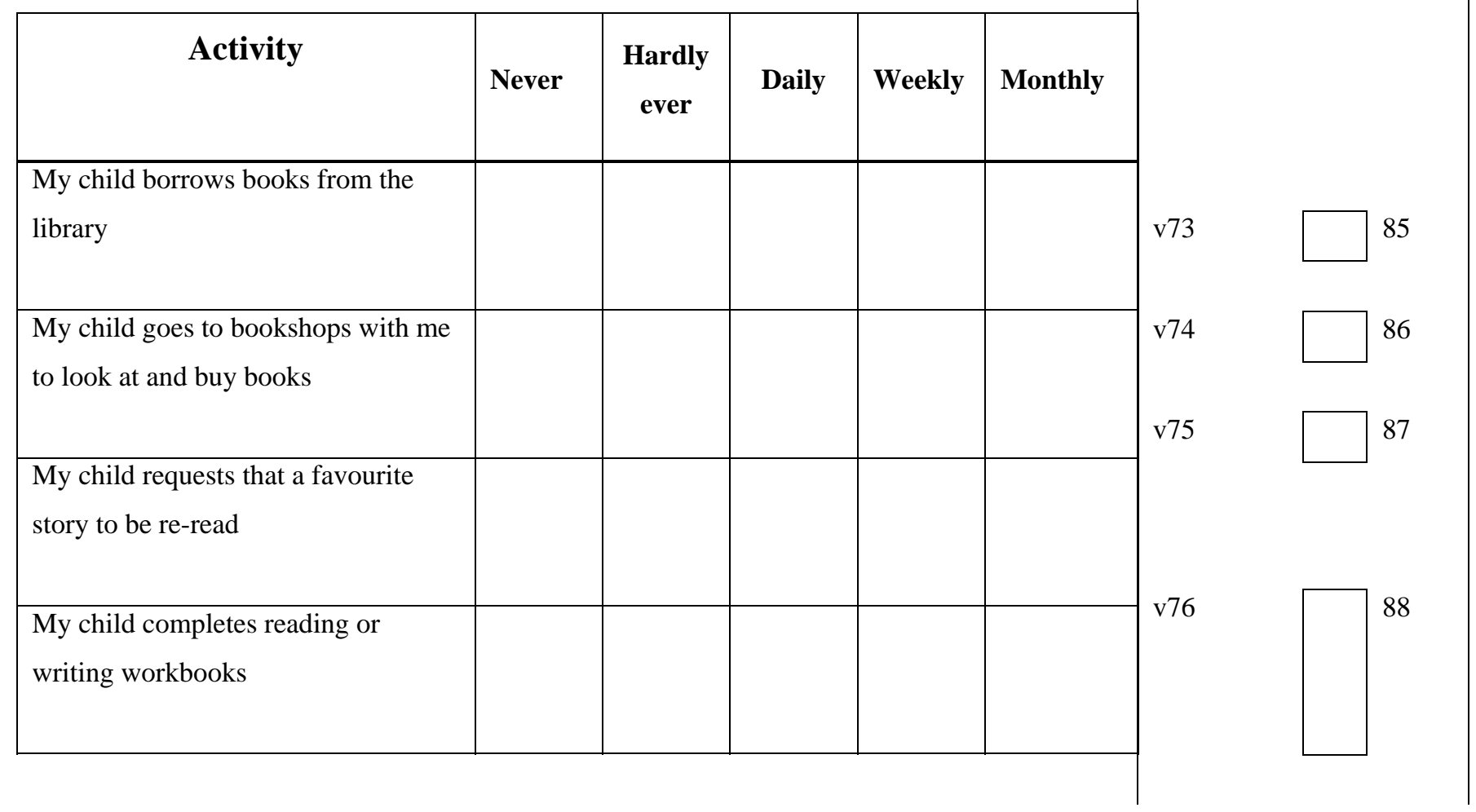


10. What time of day do you, or another family member, usually read to your child? (Please cross all the relevant blocks).

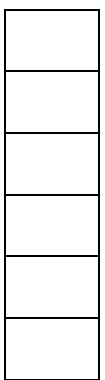

In the morning

In the afternoon

In the early evening

At bedtime

Not applicable to our routine

Other times, specify

11. Please indicate how much time per week your child engages in reading activities or looking at books. Please respond to all the statements by crossing the relevant boxes.

\begin{tabular}{|c|c|c|c|c|c|c|c|}
\hline Reading Activity & Never & $\begin{array}{c}\text { Hardly } \\
\text { ever }\end{array}$ & $\begin{array}{l}\text { Less than } \\
1 \text { hour per } \\
\text { week }\end{array}$ & $\begin{array}{c}1 \text { to } 3 \\
\text { hours per } \\
\text { week }\end{array}$ & $\begin{array}{l}\text { More than } \\
3 \text { hours } \\
\text { per week }\end{array}$ & v83 & 95 \\
\hline $\begin{array}{l}\text { You or another adult reads a story to } \\
\text { your child }\end{array}$ & & & & & & v84 & 96 \\
\hline $\begin{array}{l}\text { Your child looks at books with you } \\
\text { or with another adult }\end{array}$ & & & & & & v85 & 97 \\
\hline $\begin{array}{l}\text { Your child tells a story from a book } \\
\text { to you or to another adult }\end{array}$ & & & & & & & \\
\hline $\begin{array}{l}\text { Your child looks at books on his/her } \\
\text { own }\end{array}$ & & & & & & & \\
\hline
\end{tabular}


12. When you, or another family member, read to your child, what types of books do you usually read? (Please cross all the relevant blocks).

\begin{tabular}{|l|l}
\hline & Simple story books \\
Picture books \\
Fairy tales \\
Books with nursery rhymes \\
Children's Magazines \\
Number books \\
Children's non-fiction books \\
Alphabet books \\
Other:
\end{tabular}

13. When you, or another family member, read a book to your child, what does your child usually do? (Please cross all the relevant blocks).

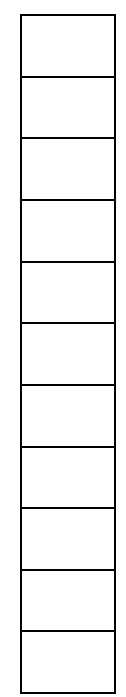

Listens attentively to the story

Looks at the pictures

Looks around with little interest

Turns the page

Grabs the book away

Tries to tear the pages

Points to the pictures

Answers your questions

Asks questions

Tries to guess what will happen next

Other:

14. When you, or another family member, read a book to your child, how does your child usually communicate with you? (Please cross all the relevant blocks).

\begin{tabular}{|l|l}
\hline & Vocalisations \\
Speech \\
Sign language \\
Gestures and pointing to pictures in the storybook \\
Signs and speech \\
Signs and vocalisations \\
Facial expressions and body language \\
Other:
\end{tabular}


15. How is your child usually positioned during story reading activities? (Please cross all the relevant blocks).

\begin{tabular}{|l|l}
\hline & Sitting opposite you at a table \\
Sitting on your lap \\
Sitting beside you on the bed \\
Sitting beside you on a sofa \\
Lying in bed at bedtime \\
Other:
\end{tabular}

16. When you read a book to your child, what do you usually do? (Please cross all the relevant blocks).

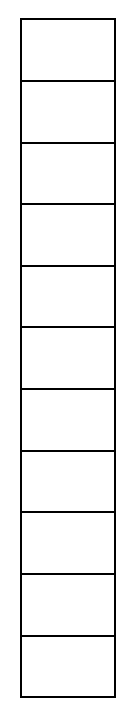

Read the text in the book

Quietly look through the book together

Point to the pictures and label them

Point to the words in the book

Point to the pictures and tell the story

Ask your child to label the pictures (e.g. What is this?)

Ask your child to point to the pictures (e.g. Where is the...? Show me the...)

Ask your child what will happen next

Ask your child to explain why something happened

Fingerspell important names and words

Other:

17. Do you think that your child enjoys reading with you?

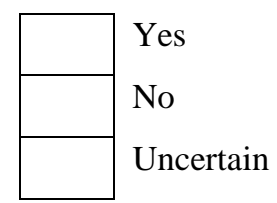

Please explain:

18. Is writing or drawing something you or other members of your family enjoy?

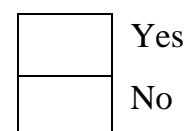

If no, please explain:

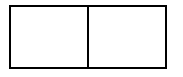


19. How often do you, or others in your family write or draw at home? (Please cross only one block).

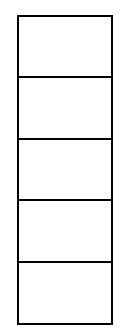

Never

2-3 times per week

Many times a day

Once a day

Other, specify

Describe these writing and drawing activities (e.g. mom writes letters, shopping lists; sister does written homework; brother draws pictures).

20. Please indicate which writing or drawing materials are readily available within your home. (Please cross all the relevant blocks).

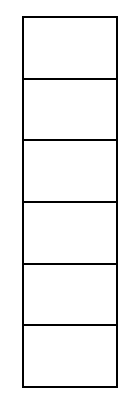

Pen/pencils and paper

Koki pens, wax crayons, glitter pens

Paints, finger paints,

Chalk and blackboard

Computer

Other:

21. How often does your child use any of the above-mentioned writing and drawing materials? (Please cross only one block).

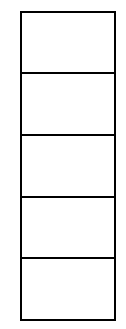

Never

2-3 times per week

Many times per day

Once a day

Other times, specify

22. Is your child interested in writing and drawing activities? (Please cross only one block).

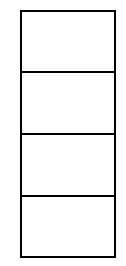

Not at all interested

Somewhat interested

Mostly interested

Very interested

How does your child show interest in writing and drawing activities?

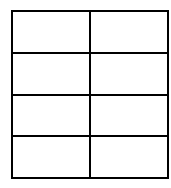

\section{.}
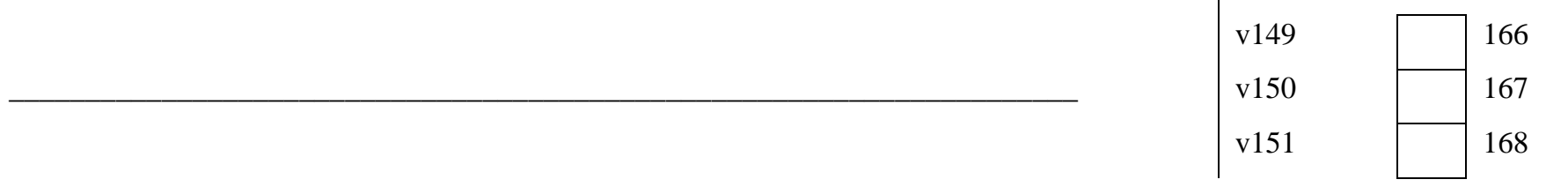
23. When your child is involved in reading and writing activities, does anyone else participate?

v152
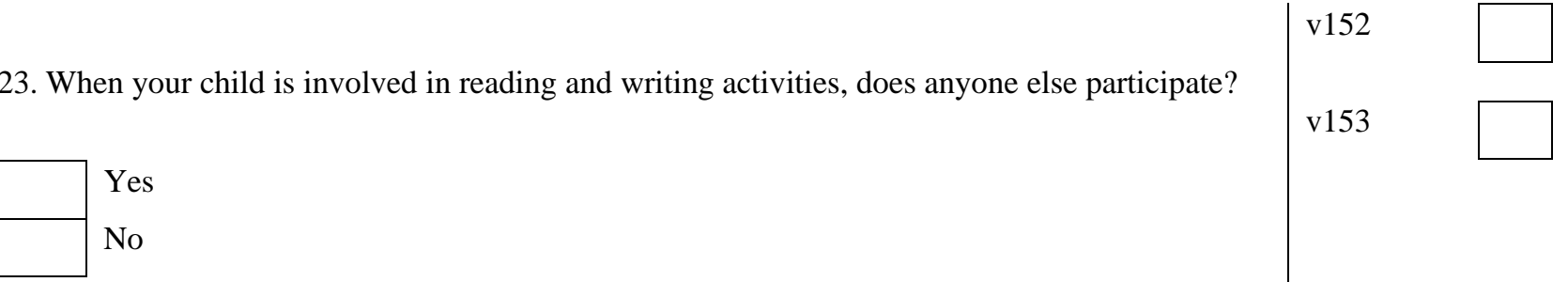

If yes, who usually participates?

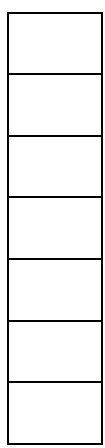

Yourself

Your spouse

Older siblings

Younger siblings

Grandparents

Friend

Other

24. Who usually initiates these reading and writing activities?

\begin{tabular}{|l|l}
\hline & Your child \\
Yourself \\
Your spouse \\
Older siblings \\
Younger siblings \\
Grandparents \\
Friends \\
Other
\end{tabular}

\begin{tabular}{|c|c|}
\hline v154 & 171 \\
\hline v155 & 172 \\
\hline v156 & 173 \\
\hline v157 & 174 \\
\hline v158 & 175 \\
\hline v159 & 176 \\
\hline v160 & 177 \\
\hline v161 & 178 \\
\hline v162 & 179 \\
\hline v163 & 180 \\
\hline v164 & 181 \\
\hline v165 & 182 \\
\hline v166 & 183 \\
\hline v167 & 184 \\
\hline v168 & 185 \\
\hline v169 & 186 \\
\hline v170 & 187 \\
\hline v171 & 188 \\
\hline v172 & 189 \\
\hline v173 & 190 \\
\hline v174 & 19 \\
\hline
\end{tabular}

25. How do siblings participate in reading and writing activities with your deaf child? (Please cross all the relevant blocks).

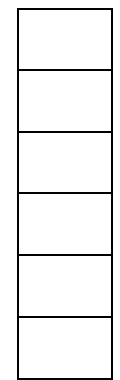

Siblings do not participate at all

Siblings read to my child

Siblings draw with my child and talk about drawings

Siblings sing nursery rhymes to my child

Siblings act out stories for/with my child

Not applicable, no siblings 
26. How important do you rate the following aspects of your child's development at the present time? Please rate each aspect from $1-5$ with $\mathbf{1}=$ least important and $\mathbf{5}=$ most important by crossing the relevant boxes.

\begin{tabular}{|l|l|l|l|l|c|}
\hline $\begin{array}{c}\text { Aspects of your child's } \\
\text { development at present }\end{array}$ & \multicolumn{4}{l|}{ Rating of importance } \\
\hline & $\begin{array}{c}\text { Least } \\
\mathbf{1}\end{array}$ & $\mathbf{2}$ & $\mathbf{3}$ & $\mathbf{4}$ & $\begin{array}{c}\text { Most } \\
\mathbf{5}\end{array}$ \\
\hline Ability to communicate with others & & & & & \\
\hline Speech development & & & & & \\
\hline Understanding of spoken language & & & & & \\
\hline Use of spoken language & & & & & \\
\hline Understanding of Sign Language & & & & & \\
\hline Use of Sign language & & & & & \\
\hline Learning to read & & & & & \\
\hline Learning to write & & & & & \\
\hline Regular exposure to books & & & & & \\
\hline Making friends & & & & & \\
\hline
\end{tabular}

\begin{tabular}{|c|c|}
\hline v175 & 192 \\
\hline v176 & 193 \\
\hline v177 & 194 \\
\hline v178 & 195 \\
\hline v179 & 196 \\
\hline v180 & 197 \\
\hline v181 & 198 \\
\hline v182 & 199 \\
\hline v183 & 200 \\
\hline v184 & 201 \\
\hline v185 & $202-3$ \\
\hline v186 & $204-5$ \\
\hline v187 & $206-7$ \\
\hline v188 & $208-9$ \\
\hline
\end{tabular}

Why are these aspects presently important to you? 
27. In your opinion, who is responsible for teaching your child to read and write? Please rate each of the following persons' responsibility from 1-5 with $\mathbf{1}=$ least responsible and 5 = most responsible by crossing the relevant boxes.

\begin{tabular}{|l|r|r|r|r|c|}
\hline \multicolumn{5}{|l|}{ Responsibility rating } \\
\hline \\
\hline
\end{tabular}

28. The following statements refer to your experiences in reading to your child. Please indicate whether you strongly disagree, disagree, agree or strongly agree with each of the statements by crossing the relevant boxes.

\begin{tabular}{|c|c|c|c|c|c|c|}
\hline Experiences of Parent. & $\begin{array}{l}\text { Strongly } \\
\text { disagree }\end{array}$ & Disagree & Agree & $\begin{array}{c}\text { Strongly } \\
\text { agree }\end{array}$ & & \\
\hline $\begin{array}{l}\text { I have difficulty in finding suitable books } \\
\text { to read to my child }\end{array}$ & & & & & v195 & 216 \\
\hline $\begin{array}{l}\text { I have difficulty communicating with my } \\
\text { child }\end{array}$ & & & & & v196 & 217 \\
\hline $\begin{array}{l}\text { I find it difficult to maintain eye contact } \\
\text { with my child during reading activities }\end{array}$ & & & & & v197 & 218 \\
\hline $\begin{array}{l}\text { I have difficulty in signing and reading at } \\
\text { the same time }\end{array}$ & & & & & v198 & 219 \\
\hline $\begin{array}{l}\text { I have difficulty in determining whether } \\
\text { my child understands the stories I read }\end{array}$ & & & & & v199 & 220 \\
\hline $\begin{array}{l}\text { I lack confidence in my ability to read to } \\
\text { my child }\end{array}$ & & & & & $\begin{array}{l}\text { v200 } \\
\text { v201 }\end{array}$ & $\begin{array}{l}221 \\
222\end{array}$ \\
\hline $\begin{array}{l}\text { I do not have enough time to read to my } \\
\text { child }\end{array}$ & & & & & v202 & 223 \\
\hline $\begin{array}{l}\text { I cannot motivate my child to be } \\
\text { interested in books }\end{array}$ & & & & & v203 & 224 \\
\hline $\begin{array}{l}\text { I have limited knowledge on how to read } \\
\text { to my child }\end{array}$ & & & & & v204 & 225 \\
\hline $\begin{array}{l}\text { At times I enjoy reading and sharing } \\
\text { books with my child }\end{array}$ & & & & & & \\
\hline
\end{tabular}


29. What are your experiences regarding the services and parental advice on literacy that you receive from your child's school? Please indicate whether you strongly disagree, disagree, agree or strongly agree with each of the following statements by crossing the relevant boxes.

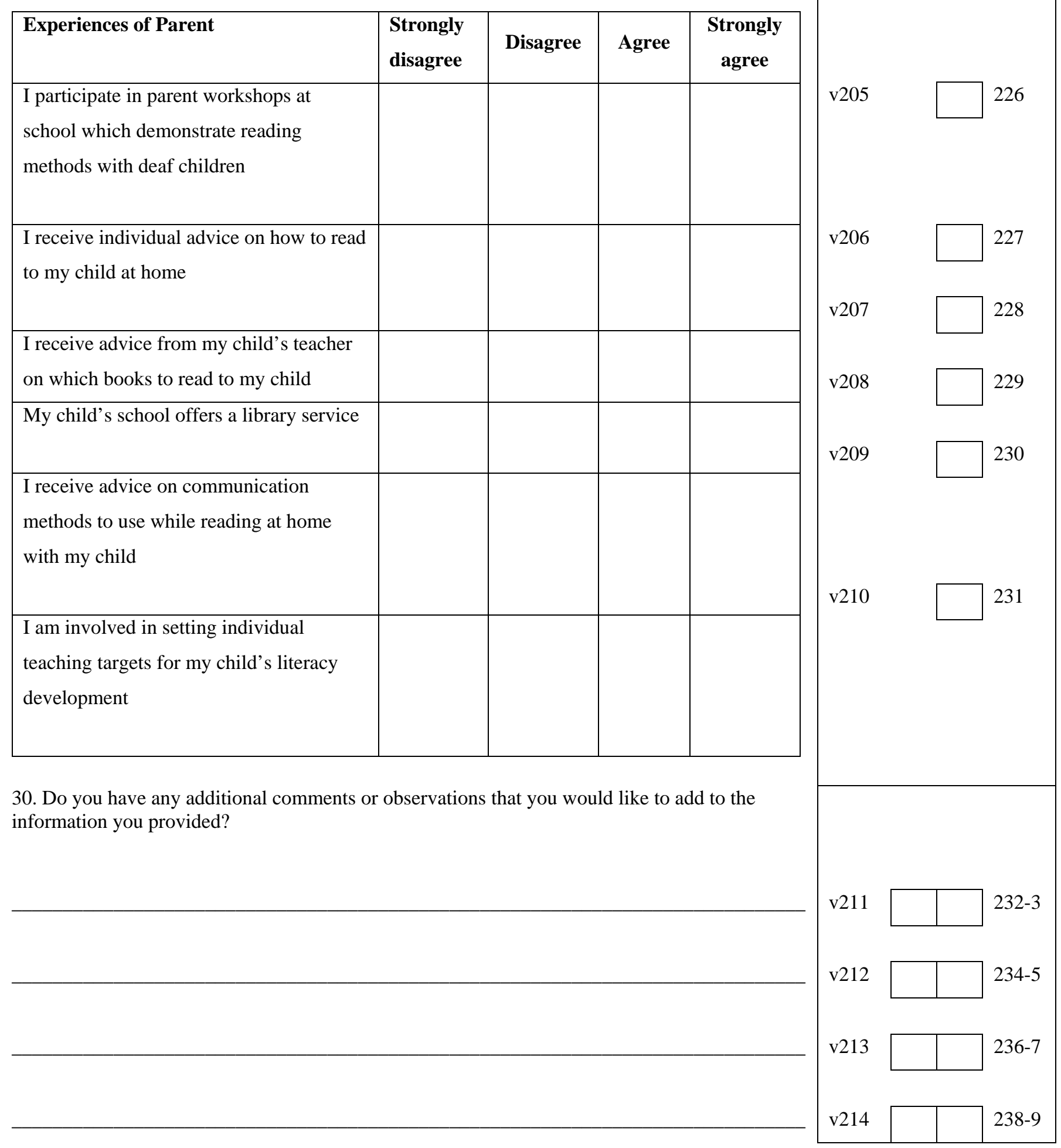


In case I need to clarify any of your responses, please will you provide your name and contact details. Please remember that your responses will remain confidential and anonymous at all times.

Name:

\section{Contact numbers:}

Daytime:

Cell phone:

I appreciate your time and effort in completing this long and involved questionnaire. Please return the questionnaire to your child's school as soon as possible. An envelope, marked for my attention, is included for convenience and confidentiality.

Thank you once again for your participation in this research project.

\section{Carlin Stobbart}

Centre for Augmentative and Alternative Communication

University of Pretoria 


\section{APPENDIX E}

\section{VRAELYS}

\section{Afdeling A:}

\section{Agtergrondinligting oor die persoon wat die vraelys voltooi}

1. Wat is u verwantskap tot die dowe kind?

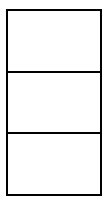

Moeder

Vader

Versorger, spesifiseer:

2. Wat is u ouderdom?

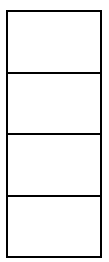

20-30 jaar

31-40 jaar

41-50 jaar

51 jaar en ouer

3. Wat is u huwelikstatus?

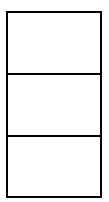

Enkel, nooit getroud nie

Getroud

Geskei

4. Wat is u hoogste opvoedkundige kwalifikasie?

Minder as 10 jaar op skool

10-12 jaar op skool

2-3 jaar na skool

4 of meer jaar na skool 
5. Wat is u huidige werkstatus?

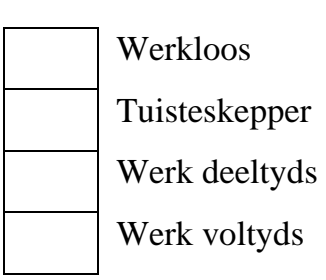

6. Wat is u eggenoot se huidige werkstatus?

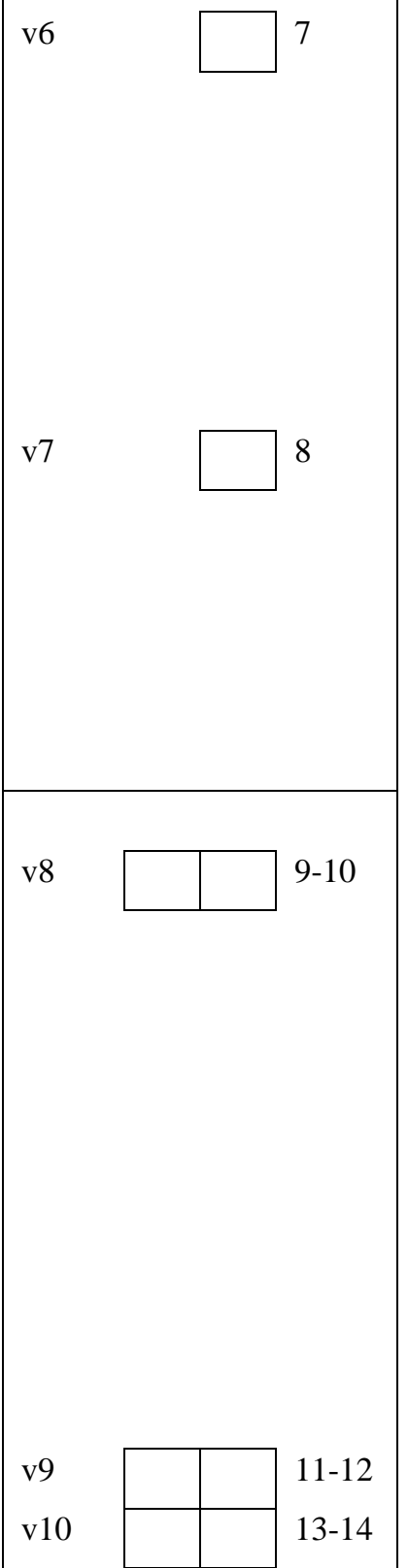

7. Wat is u huistaal?

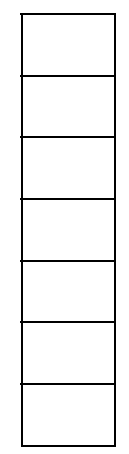

Afrikaans

Engels

Sotho

Zulu

Xhosa

Gebaretaal

Ander, spesifiseer:

8. Watter ander tale word in u huis gebruik?

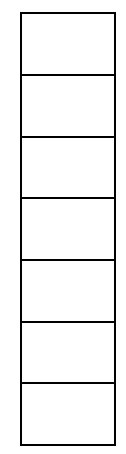

Afrikaans

Engels

Sotho

Zulu

Xhosa

Gebaretaal

Ander, spesifiseer: 
Afdeling B:

\section{Agtergrondinligting oor u dowe kind}

1. Hoe oud is u kind?

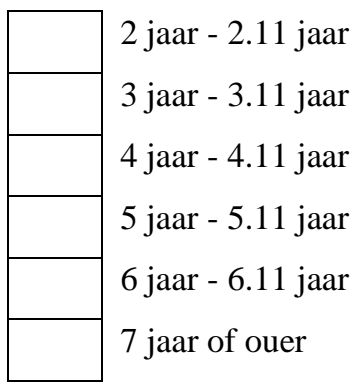

2. Het u kind ander broers en/of susters?

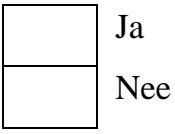

Indien wel, dui asb. die ouderdomme en vlak van gehoor van die ander kinders in u huishouding aan.

\begin{tabular}{|c|c|c|c|c|}
\hline \multicolumn{2}{|c|}{ Broer/Suster } & \multicolumn{2}{|c|}{ Vlak van Gehoor } & \\
\hline Broer & Suster & Doof & Horend & Ouderdom \\
\hline & & & & \\
\hline & & & & \\
\hline & & & & \\
\hline
\end{tabular}

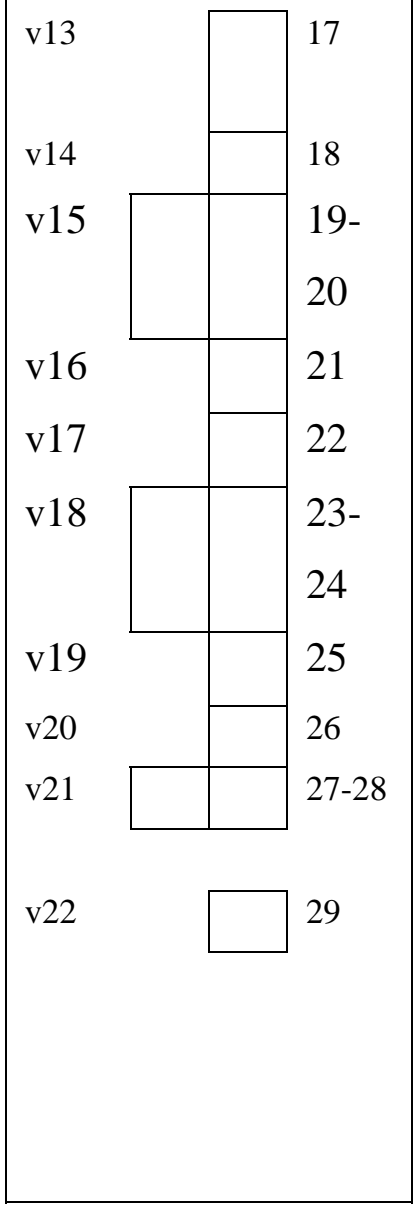

3. Op watter ouderdom was u kind se doofheid gediagnoseer?

\begin{tabular}{|l|l}
\hline & $\begin{array}{l}0-12 \text { maande } \\
13-24 \text { maande } \\
25-36 \text { maande } \\
\text { Na } 3 \text { jaar }\end{array}$
\end{tabular}


4. Dui asseblief aan hoe u met u kind kommunikeer.

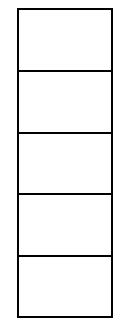

Slegs spraak

Slegs Gebaretaal

Spraak en Gebare

Spraak en natuurlike gebare

Spraak, Gebaretaal en natuurlike gebare

5. Dui asseblief aan watter van die volgende klankversterkingsisteme u kind gebruik. (Maak asb. kruisies in al die toepaslike blokkies).

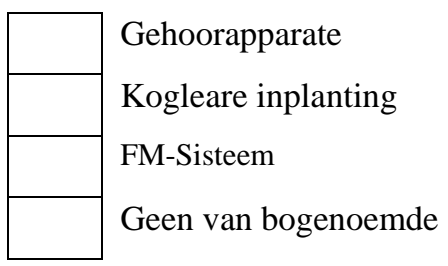

\section{Afdeling C:}

\section{Inligting oor u dowe kind se aktiwiteite}

1. Wat is u kind se gunsteling aktiwiteite? (Maak asb. kruisies in al die toepaslike blokkies).

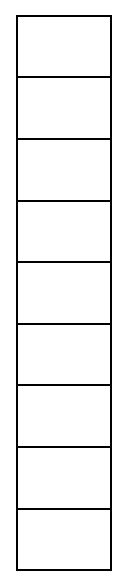

Kyk na boeke

Lees saam met 'n volwassene

Kyk TV

Teken alleen

Teken saam met ander gesinslede

Speel buite

Speel binne

Sportaktiwiteite

Ander, spesifiseer:

2. Toon u, of ander lede van u gesin, belangstelling in leesaktiwiteite? (Maak asb. 'n kruisie in slegs een blokkie).

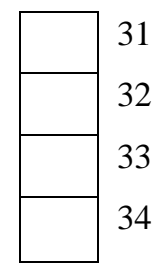

.


3. Hoe dikwels lees u of ander gesinslede tuis, in die teenwoordigheid van u dowe kind? (Maak asb. 'n kruisie in slegs een blokkie).

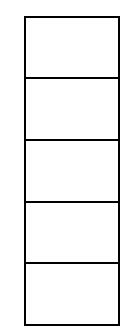

\section{Nooit}

2-3 keer per week

Baie keer per dag

Eenmaal per dag

Ander, spesifiseer:

Beskryf asseblief hierdie leesaktiwiteite (bv. Ma lees storieboeke, resepte, werksverwante leesstof; Pa lees koerant, tydskrifte; broers en susters lees skoolboeke).

4. Watter van die volgende gedrukte media is geredelik in u huis beskikbaar? (Maak asb. kruisies in al die toepaslike blokkies).

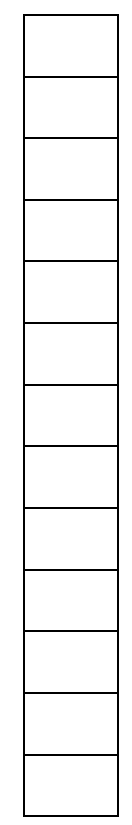

\section{Tydskrifte}

Storieboeke

Nie-fiksie

Koffietafelboeke

Resepteboeke

TV-Gidse

Koerante

Katalogusse

Briewe / e-pos

Kinderstorieboeke

Kindertydskrifte

Kinderprenteboeke

Ander:

5. Hoe dikwels gebruik u kind enige van die bogenoemde gedrukte media? (Maak asb. 'n kruisie in slegs een blokkie).

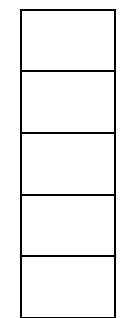

\section{Nooit}

2-3 keer per week

Baie keer per dag

Eenkeer per dag

Ander, spesifiseer:

Wat is u kind se gunsteling gedrukte media? (Wees asb. spesifiek).

7
8
9


6. Toon u kind belangstelling in leesaktiwiteite? (Maak asb. 'n kruisie in slegs een blokkie).

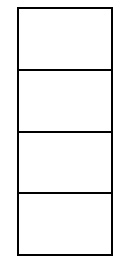

Geen belangstelling nie

Min belangstelling

Heelwat belangsteelling

Baie belangstelling

Hoe toon hy/sy belangstelling in leesaktiwiteite?

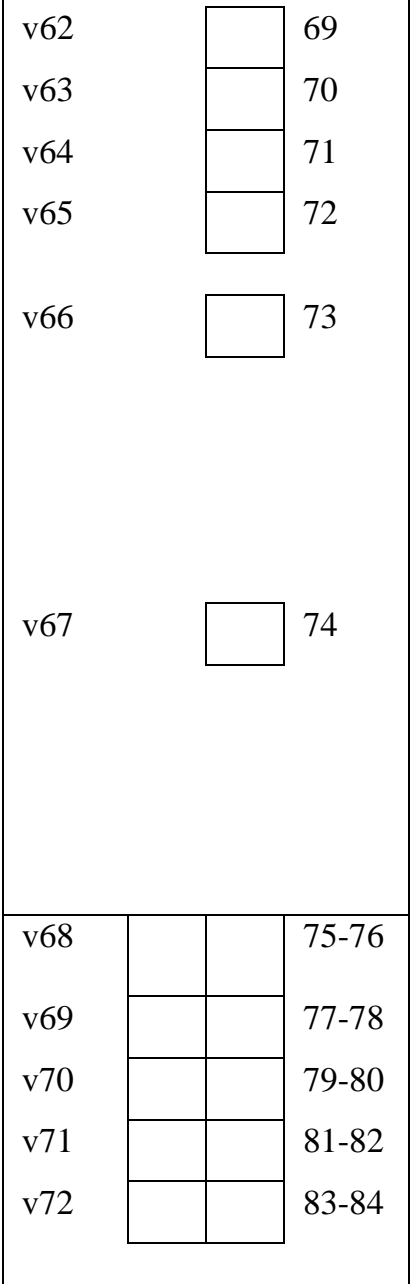

7. Besit u kind enige boeke van sy/haar eie?

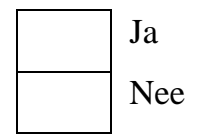

Indien wel, ongeveer hoeveel boeke?

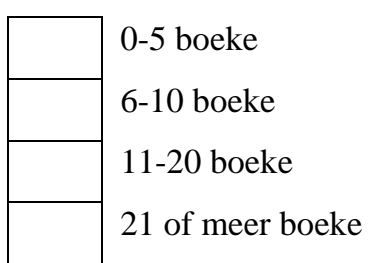

8. Wat is u kind se gunsteling boeke? (Veskaf asb. die titels van die boeke). 
9. Dui asb. aan hoe dikwels u kind aan elkeen van die volgende aktiwiteite deelneem. Antwoord asb. op al die stellings, deur kruisies in die toepaslike blokkies te maak.

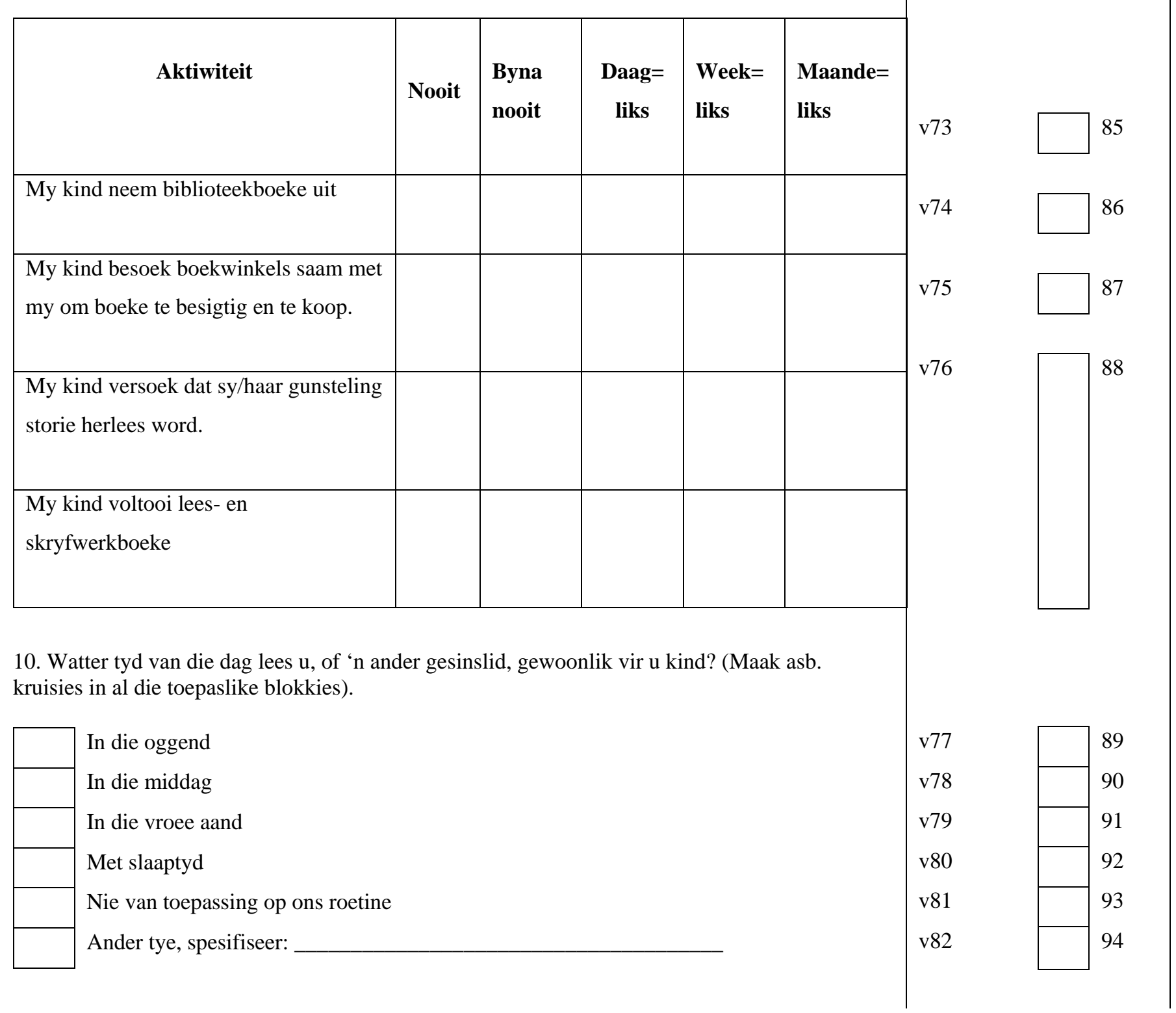


11. Dui asb. aan hoeveel tyd per week u kind bestee aan leesaktiwiteite of om na boeke te kyk. Antwoord asb. op al die stellings deur kruisies in die toepaslike blokkies te maak.

\begin{tabular}{|c|c|c|c|c|c|c|c|}
\hline Leesaktiwiteite & Nooit & $\begin{array}{l}\text { Byna } \\
\text { nooit }\end{array}$ & $\begin{array}{l}\text { Minder as } \\
1 \text { uur per } \\
\text { week }\end{array}$ & $\begin{array}{l}1 \text { tot } 3 \text { ure } \\
\text { per week }\end{array}$ & $\begin{array}{c}\text { Meer as } 3 \\
\text { ure per } \\
\text { week }\end{array}$ & v83 & 95 \\
\hline $\begin{array}{l}\text { U of ' } n \text { volwassene lees ' } n \text { storie vir } \\
\text { u kind }\end{array}$ & & & & & & v84 & 96 \\
\hline $\begin{array}{l}\text { U kind kyk saam met u of ' } \mathrm{n} \text { ander } \\
\text { volwassene na boeke }\end{array}$ & & & & & & v85 & 97 \\
\hline $\begin{array}{l}\text { U kind vertel 'n storie uit 'n boek } \\
\text { aan u of aan'n ander volwassene }\end{array}$ & & & & & & & \\
\hline U kind kyk alleen na boeke & & & & & & & \\
\hline $\begin{array}{l}\text { 12. Watter tipe boeke lees u gewoon } \\
\text { asb. kruisies in al die toepaslike blokk }\end{array}$ & rann & of ${ }^{\prime}$ & der gesins & jir u kind & ? (Maak & & \\
\hline Eenvoudige storieboeke & & & & & & v87 & 99 \\
\hline Prenteboeke & & & & & & v88 & 100 \\
\hline Feeverhale & & & & & & v89 & 101 \\
\hline Boeke met kleuterrympies & & & & & & v90 & 102 \\
\hline Kindertydskrifte & & & & & & v91 & 103 \\
\hline Getalboeke & & & & & & v92 & 104 \\
\hline Nie-fiksie kinderboeke & & & & & & v93 & 105 \\
\hline Alfabetboeke & & & & & & v94 & 106 \\
\hline Ander: & & & & & & v95 & 107 \\
\hline
\end{tabular}


13. Wat doen u kind gewoonlik wanneer u of ' $n$ ander gesinslid ' $n$ boek vir u kind lees? (Maak asb. kruisies in al die toepaslike blokkies).

\begin{tabular}{|l|l}
\hline & Luister aandagtig na die storie \\
Kyk na die prente \\
Kyk rond met min belangstelling \\
Blaai die bladsye om \\
Gryp die boek weg \\
Probeer die bladsye skeur \\
Wys na die prente \\
Antwoord u vrae \\
Vra vrae \\
Probeer raai wat volgende gaan gebeur \\
Ander:
\end{tabular}

14. Hoe kommunikeer $\mathbf{u}$ kind gewoonlik met u wanneer u of ' $n$ ander gesinslid ' $n$ boek vir $u$ kind lees? (Maak asb. kruisies in al die toepaslike blokkies).

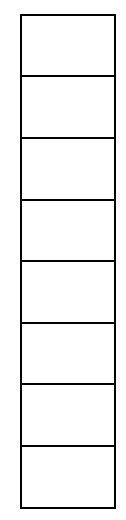

Vokaliserings

Spraak

Gebaretaal

Natuurlike gebare en wys na prente in die storieboek

Gebare en spraak

Gebare en vokaliserings

Gesigsuidrukkings en liggaamstaal

Ander:

15. Hoe is u kind gewoonlik geposisioneer gedurende leesaktiwiteite? (Maak asb. kruisies in al die toepaslike blokkies).

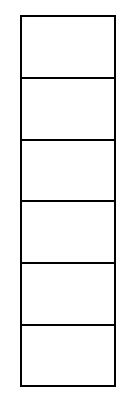

Sit oorkant u by die tafel

Sit op u skoot

Sit langs u op die bed

Sit langs u op 'n rusbank

Le in die bed teen slaaptyd

Ander: 
16. Wat doen u gewoonlik wanneer u ' $n$ boek vir u kind lees? (Maak asb. kruisies in al die toepaslike blokkies).

\begin{tabular}{|l|l}
\hline & Lees die teks in die boek \\
Kyk stil saam deur die boek \\
Wys na en benoem die prente in die boek \\
Wys na die woorde in die boek \\
Wys na die prente en vertel die storie \\
Vra u kind om die prente te benoem (bv. Wat is dit?) \\
Vra u kind om na die prente te wys (bv. Waar is die...? Wys vir my die...) \\
Vra u kind wat volgende gaan gebeur \\
Vra u kind 'n verduideliking van wat gebeur het \\
Vingerspelling van belangrike name en woorde \\
Ander:
\end{tabular}

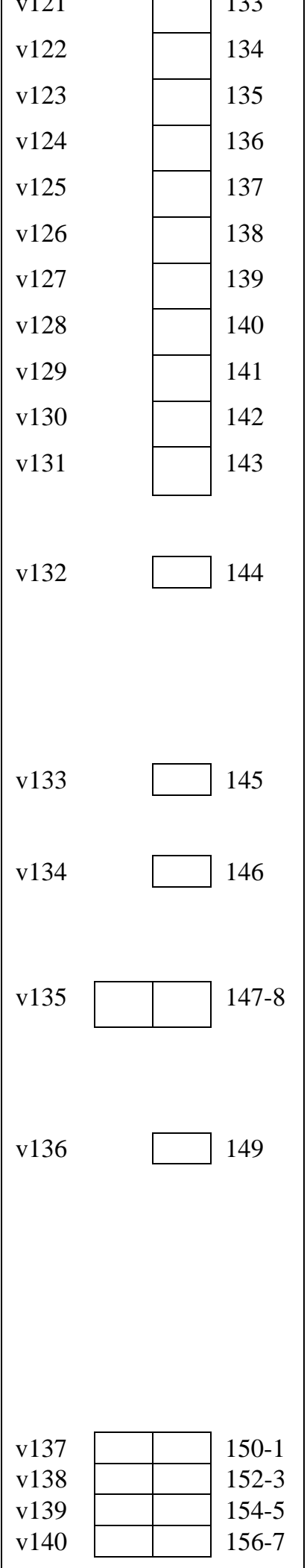

17. Dink u dat u kind dit geniet om saam met u te lees?

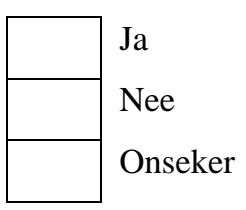

Verduidelik asb.:

18. Geniet u en ander lede van u gesin skryf- en tekenaktiwiteite?

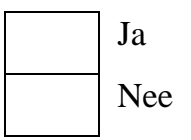

Indien nie, verduidelik asb.

19. Hoe dikwels skryf of teken u of ander gesinslede by die huis? (Maak asb. 'n kruisie in slegs een blokkie).

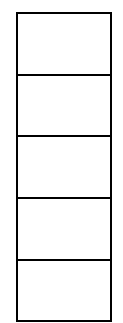

Nooit

2-3 keer per week

Baie keer per dag

Eenmaal per dag

Ander, spesifiseer:

Beskryf asb. die skryf- en tekenaktiwiteite (bv. Ma skryf briewe, inkopielyste; susters doen skriftelike skoolwerk; broers teken prentjies). 
20. Dui asb. aan watter skryf- en tekenmateriaal geredelik in u huis beskikbaar is. (Maak asb. kruisies in al die toepaslike blokkies).

\begin{tabular}{|l|l}
\hline & \begin{tabular}{l} 
Penne/potlode en papier \\
Kokipenne, vetkryte, glinsterpenne \\
Verf, vingerverf \\
Kryt en swartbord \\
Rekenaar \\
\cline { 1 - 1 } Ander:
\end{tabular} \\
\hline
\end{tabular}

\begin{tabular}{|l|l|} 
v141 & 158 \\
v142 & 159 \\
v143 & 160 \\
v145 & 161 \\
v146 & 162 \\
\cline { 2 - 2 } & 163 \\
\hline
\end{tabular}

21. Hoe dikwels gebruik u kind enige van die bogenoemde skryf- en tekenmateriaal? (Maak asb. ' $\mathrm{n}$ kruisie in slegs een blokkie).

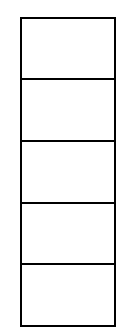

\section{Nooit}

2-3 keer per week

Baie keer per day

Eenmaal per dag

Ander, spesifiseer:

22. Toon u kind belangstelling in skryf- en tekenaktiwiteite? (Maak asb. 'n kruisie in slegs een blokkie).

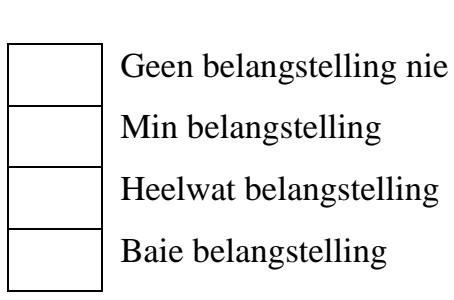

Hoe toon u kind sy/haar belangstelling in skryf- en tekenaktiwiteite? 
23. Neem ander persone deel wanneer u kind besig is met lees- en skryfaktiwiteite?

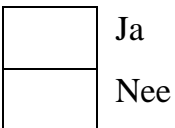

Indien wel, wie neem gewoonlik deel?

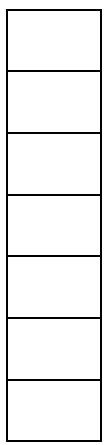

Uself

U eggenoot

Ouer broers of susters

Jonger broers of susters

Oupa of Ouma

Vriend

Ander

24. Wie begin gewoonlik hierdie lees- en skryfaktiwiteite?

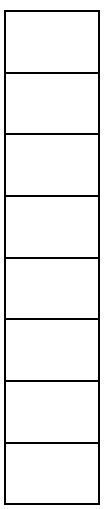

U kind

Uself

U eggenoot

Ouer broers of susters

Jonger broers of susters

Oupa of Ouma

Vriende

Ander

25. Hoe neem broers en/of susters deel aan lees- en skryfaktiwiteite met u dowe kind? (Maak asb. kruisies in al die toepaslike blokkies).

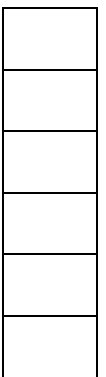

Broers/susters neem glad nie deel nie

Broers/susters lees vir my kind

Broers/susters teken saam met my kind en gesels oor die tekeninge

Broers/susters sing kleuterrympies vir my kind

Broers/susters voer stories op vir/saam my kind

Nie van toepassing nie, geen broers en/of susters

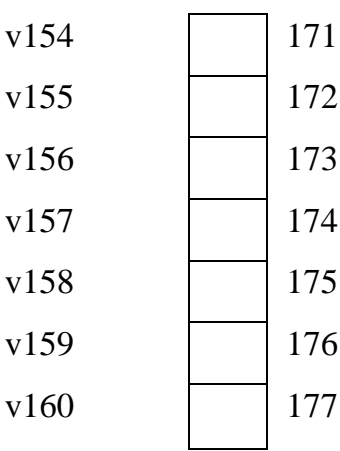

v161

v162

v163

v164

v165

v166

v167

v168

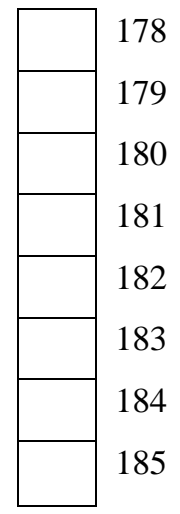

\begin{tabular}{|l|l|}
\hline & 186 \\
187 \\
\cline { 1 - 1 } 188 \\
189 \\
190 \\
\cline { 1 - 1 } \\
\cline { 1 - 1 } \\
\cline { 1 - 1 }
\end{tabular}


26. Hoe belangrik ag u die volgende aspekte van u kind se ontwikkeling op die huidige oomblik? Gradeer asb. elke aspek van 1-5 waar $\mathbf{1}$ = minste belangrik en $\mathbf{5}=$ meeste belangrik aandui. Maak asb. kruisies in al die toepaslike blokkies.

\begin{tabular}{|l|c|c|c|c|c|}
\hline \multicolumn{2}{|c|}{$\begin{array}{c}\text { Aspek van u kind se } \\
\text { ontwikkeling huidiglik }\end{array}$} & \multicolumn{4}{l|}{ Graad van belangrikheid } \\
\hline & $\begin{array}{c}\text { Minste } \\
\mathbf{1}\end{array}$ & $\mathbf{2}$ & $\mathbf{3}$ & $\mathbf{4}$ & $\begin{array}{c}\text { Meeste } \\
\mathbf{5}\end{array}$ \\
\hline $\begin{array}{l}\text { Vermoee om met ander te } \\
\text { kommunikeer }\end{array}$ & & & & & \\
\hline Spraakontwikkeling & & & & & \\
\hline Begrip van gesproke taal & & & & & \\
\hline Gebruik van gesproke taal & & & & & \\
\hline Begrip van Gebaretaal & & & & & \\
\hline Gebruik van Gebaretaal & & & & & \\
\hline Leer om te lees & & & & & \\
\hline Leer om te skryf & & & & & \\
\hline Gereelde blootstelling aan boeke & & & & & \\
\hline Vriende maak & & & & & \\
\hline
\end{tabular}

Hoekom is hierdie aspekte huidiglik vir u belangrik?

\begin{tabular}{|c|c|}
\hline v175 & 192 \\
\hline v176 & 193 \\
\hline v177 & 194 \\
\hline v178 & 195 \\
\hline v179 & 196 \\
\hline v180 & 197 \\
\hline v181 & 198 \\
\hline v182 & 199 \\
\hline v183 & 200 \\
\hline v184 & 201 \\
\hline v185 & $202-3$ \\
\hline v186 & 204-5 \\
\hline v187 & $206-7$ \\
\hline v188 & $208-9$ \\
\hline
\end{tabular}


27. Wie se verantwoordelikheid is dit, volgens u, om u kind te leer lees en skryf? Gradeer asb. elkeen van die volgende persone se verantwordelikheid van 1-5 waar 1 = minste verantwoordelikheid en $\mathbf{5}=$ meeste verantwoordelikheid aandui. Maak asb. kruisies in al die toepaslike blokkies.

\begin{tabular}{|l|c|c|c|c|c|}
\hline \multirow{2}{*}{ Persoon } & \multicolumn{5}{|c|}{ Graad van verantwoordelikheid } \\
\hline & $\begin{array}{c}\text { Minste } \\
\mathbf{1}\end{array}$ & $\mathbf{2}$ & $\mathbf{3}$ & $\mathbf{4}$ & $\begin{array}{c}\text { Meeste } \\
\mathbf{5}\end{array}$ \\
\hline Moeder & & & & & \\
\hline Vader & & & & & \\
\hline Broers/susters & & & & & \\
\hline Oupa/Ouma & & & & & \\
\hline Onderwyseres & & & & & \\
\hline Vriende & & & & & \\
\hline
\end{tabular}


28. Die volgende stellings verwys na u leeservaringe met u kind. Dui asb. aan of u glad nie saamstem nie, nie saamstem nie, saamstem of heeltemal saamstem met elkeen van die stellings. Maak asb. kruisies in al die toepaaslike blokkies.

\begin{tabular}{|c|c|c|c|c|c|c|}
\hline Ervaringe van die Ouer. & $\begin{array}{l}\text { Stem glad } \\
\text { nie saam } \\
\text { nie }\end{array}$ & $\begin{array}{l}\text { Stem nie } \\
\text { saam nie }\end{array}$ & $\begin{array}{l}\text { Stem } \\
\text { saam }\end{array}$ & $\begin{array}{c}\text { Stem } \\
\text { heeltemal } \\
\text { saam }\end{array}$ & \multirow[b]{2}{*}{ v195 } & \multirow[b]{2}{*}{216} \\
\hline $\begin{array}{l}\text { Ek sukkel om geskikte boeke te kry om } \\
\text { vir my kind te lees }\end{array}$ & & & & & & \\
\hline $\begin{array}{l}\text { Ek ondervind probleme om met my kind } \\
\text { te kommunikeer }\end{array}$ & & & & & v196 & 217 \\
\hline $\begin{array}{l}\text { Ek vind dit moeilik om oogkontak met } \\
\text { my kind te behou tydens leesaktiwiteite }\end{array}$ & & & & & v197 & 218 \\
\hline $\begin{array}{l}\text { Ek vind dit moeilik om te lees en } \\
\text { terselfdertyd Gebaretaal te gebruik }\end{array}$ & & & & & v198 & 219 \\
\hline $\begin{array}{l}\text { Ek vind dit moeilik om te bepaal of my } \\
\text { kind die stories wat ek lees, verstaan }\end{array}$ & & & & & v199 & 220 \\
\hline $\begin{array}{l}\text { Ek het nie genoeg vertroue in my } \\
\text { vermoee om vir my kind te lees nie }\end{array}$ & & & & & $\begin{array}{l}\text { v200 } \\
\text { v201 }\end{array}$ & $\begin{array}{l}221 \\
222\end{array}$ \\
\hline $\begin{array}{l}\text { Ek het nie genoeg tyd om vir my kind te } \\
\text { lees nie }\end{array}$ & & & & & v202 & 223 \\
\hline $\begin{array}{l}\text { Ek kan nie my kind motiveer om in boeke } \\
\text { belang te stel nie }\end{array}$ & & & & & v203 & 224 \\
\hline $\begin{array}{l}\text { Ek het nie genoegsame kennis oor hoe om } \\
\text { vir my kind te lees nie }\end{array}$ & & & & & v204 & 225 \\
\hline $\begin{array}{l}\text { Met tye geniet ek dit om vir my kind te } \\
\text { lees en saam met hom/haar na boeke te } \\
\text { kyk }\end{array}$ & & & & & & \\
\hline
\end{tabular}


29. Wat is u ervaringe met betrekking tot die dienste en ouerraad oor geletterdheid wat u van u kind se skool ontvang? Dui asb. aan of u glad nie saamstem nie, nie saamstem nie, saamstem of heeltemal saamstem met elkeen van die volgende stellings deur kruisies in die toepaslike blokkies te maak.

\begin{tabular}{|c|c|c|c|c|c|c|}
\hline Ervaringe van die Ouer & $\begin{array}{l}\text { Stem gald } \\
\text { nie saam } \\
\text { nie }\end{array}$ & $\begin{array}{l}\text { Stem nie } \\
\text { saam nie }\end{array}$ & $\begin{array}{l}\text { Stem } \\
\text { saam }\end{array}$ & $\begin{array}{c}\text { Stem } \\
\text { heeltemal } \\
\text { saam }\end{array}$ & & \\
\hline $\begin{array}{l}\text { Ek neem deel aan werksessies vir ouers } \\
\text { by die skool, waar leesmetodes met dowe } \\
\text { kinders gedemonstreer word }\end{array}$ & & & & & v205 & 226 \\
\hline $\begin{array}{l}\text { Ek ontvang individuele ouerraad oor hoe } \\
\text { om tuis vir my kind te lees }\end{array}$ & & & & & v206 & 227 \\
\hline $\begin{array}{l}\text { Ek kry raad van my kind se onderwyseres } \\
\text { oor watter boeke ek vir my kind kan lees }\end{array}$ & & & & & v207 & 228 \\
\hline $\begin{array}{l}\text { My kind se skool verskaf ' } n \\
\text { biblioteekdiens }\end{array}$ & & & & & v208 & 229 \\
\hline $\begin{array}{l}\text { Ek ontvang raad oor } \\
\text { kommunikasiemetodes om te gebruik } \\
\text { wanneer ek tuis vir my kind lees }\end{array}$ & & & & & v209 & 230 \\
\hline $\begin{array}{l}\text { Ek is betrokke in die daarstelling van } \\
\text { individuele onderwysdoelwitte vir die } \\
\text { ontwikkeling van my kind se } \\
\text { geletterdheid }\end{array}$ & & & & & v210 & 231 \\
\hline \multicolumn{7}{|c|}{$\begin{array}{l}\text { 30. Het u enige addisionele aanmerkings of waarnemings wat u graag wil byvoeg tot die inligting } \\
\text { wat u reeds verskaf het? }\end{array}$} \\
\hline & & & & & v211 & $232-3$ \\
\hline & & & & & v212 & $234-5$ \\
\hline & & & & & v213 & $236-7$ \\
\hline & & & & & v214 & $238-9$ \\
\hline
\end{tabular}


Ingeval ek duidelikheid benodig oor enige van die antwoorde wat u verskaf het, vul asseblief u naam en kontak nommers in. Onthou asseblief dat u antwoorde te alle tye vertroulik en anoniem sal bly.

Naam:

Kontak nommers:

Dag:

Selfoon:

Ek waardeer u tyd en inspanning om hierdie lang en omvattende vraelys te voltooi. Stuur asseblief so gou as moontlik die voltooide vraelys terug na u kind se skool. Vir gerieflikheid en vertroulikheid, sluit ek 'n koevert, gemerk vir my aandag, in.

Weereens baie dankie vir u deelname aan hierdie navorsingsprojek.

\section{Carlin Stobbart}

Sentrum vir Aanvullende en Alternatiewe Kommunikasie

Universiteit van Pretoria 


\section{APPENDIX F \\ COVERING LETTER TO THE QUESTIONNAIRE IN ENGLISH AND \\ AFRIKAANS}

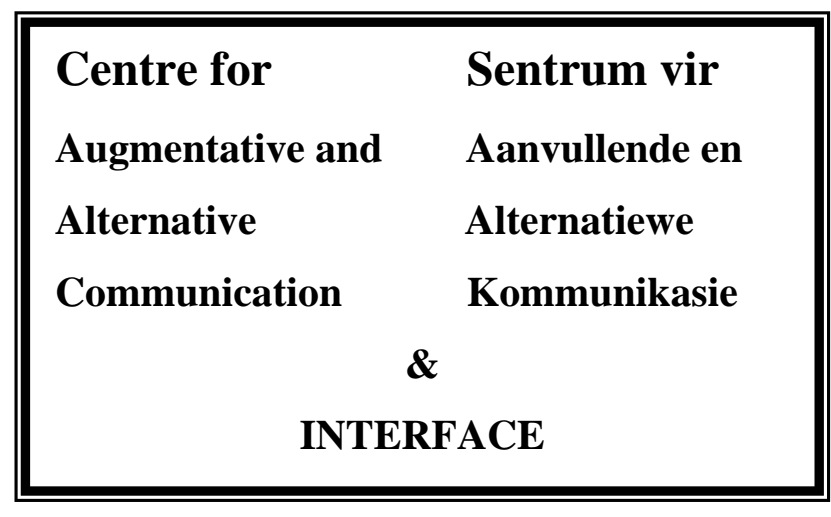

T-Systems Age of Innovation \& Sustainability Awards: Excellence in Innovation and Sustainability: Social National Science \& Technology Awards: Corporate Organization over the last ten years.

Shirley McNaughton Award for Exemplary Communication received from the International Society for Augmentative and Alternative Communication

Rolex Award for Enterprise: Associate Laureate

1995: Education Africa Presidential Award for Special Needs

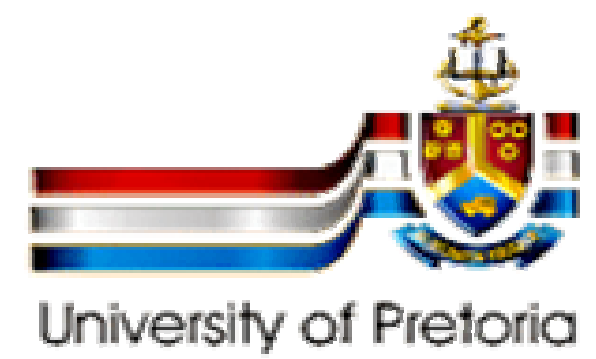

website: http://www.up.ac.za/academic/caac Fax/Faks: (012) 420 - 4389

Tel: (012) $420-2001$

E-mail: erna.alant@up.ac.za

Faculty of Education / Fakulteit Opvoedkunde

Centre for Augmentative and Alternative Communication Sentrum vir Aanvullende en Alternatiewe Kommunikasie

Dear

Thank you for your willingness to participate in this research project. Your input and unique contributions are important in describing the home-based literacy experiences of severe to profoundly deaf pre-schoolers. Please note that a copy of the final research report will be made available to the school. I once again wish to assure you that your responses will remain confidential and anonymous.

When you complete this questionnaire, please:

- Answer all the questions with reference to your deaf child

- There are no correct or incorrect answers - your unique experiences are valuable

- Complete all the questions

- Provide additional information where requested

- Provide as much detail as you can

- Place a cross in the appropriate block 
- Cross more than one block where appropriate

- Your general comments and observations will be appreciated.

Please return the questionnaire to your child's teacher using the enclosed envelope addressed to me. I will personally collect the completed questionnaires from the school. Thank you once again for your time in completing this questionnaire.

Kind regards

Carlin Stobbart

Contact Number: 0836390930 


\begin{tabular}{|ll|}
\hline Centre for & \multicolumn{1}{c|}{ Sentrum vir } \\
Augmentative and & Aanvullende en \\
Alternative & Alternatiewe \\
Communication & \multicolumn{2}{c|}{ Kommunikasie } \\
& \& \\
& \multicolumn{2}{|c|}{ INTERFACE } \\
\hline
\end{tabular}

2004 T-Systems Age of Innovation \& Sustainability Awards: Excellence in Innovation and Sustainability: Social

2003 National Science \& Technology Awards: Corporate Organization over the last ten years.

2002: Shirley McNaughton Award for Exemplary Communication received from the International Society for Augmentative and Alternative Communication

1998: Rolex Award for Enterprise: Associate Laureate 1995: Education Africa Presidential Award for Special Needs

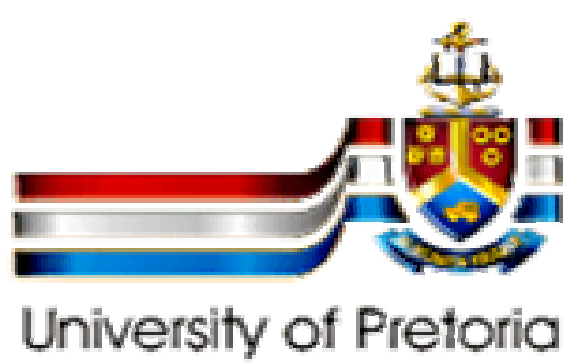

website: http://www.up.ac.za/academic/caac Fax/Faks: (012) 420 - 4389

Tel: (012) 420 - 2001

E-mail: erna.alant@up.ac.za

Faculty of Education / Fakulteit Opvoedkunde Centre for Augmentative and Alternative Communication Sentrum vir Aanvullende en Alternatiewe Kommunikasie

9 Junie 2005

Geagte

Baie dankie dat u bereid is om aan hierdie navorsingsprojek deel te neem. U bydraes en unieke ervarings is belangrik om jong dowe kinders se vroee blootstelling aan geletterdheid te beskryf. Let asseblief daarop dat ' $n$ kopie van die navorsingsverslag aan die skool beskikbaar gemaak sal word. Ek wil u weereens verseker dat u antwoorde vertroulik en anoniem sal bly.

As riglyne om die vraelys te voltooi, let asseblief op die volgende:

- Antwoord al die vrae met verwysing na u dowe kind

- Daar is geen korrekte of verkeerde antwoorde is nie - $\mathbf{u}$ unieke ervarings is waardevol

- Antwoord al die vrae

- Verskaf addisionele inligting waar benodig

- Verskaf soveel besonderhede as moontlik

- Maak kruisies in die toepaslike blokkies

- Waar nodig, maak kruisies in meer as een blokkie

- $\mathrm{U}$ algemene opmerkings en waarnemings sal waardeer word 
Stuur asseblief die voltooide vraelys terug na u kind se skool in die ingeslote koevert. Ek sal die vraelyste persoonlik by die skool gaan haal. Weereens, baie dankie vir u tyd om hierdie vraelys te voltooi.

\section{Vriendelike Groete}

\section{Carlin Stobbart}

Kontaknommer: 0836390930 


\section{APPENDIX G \\ LETTER OF PERMISSION TO CONDUCT THE RESEARCH: GAUTENG DEPARTMENT OF EDUCATION}

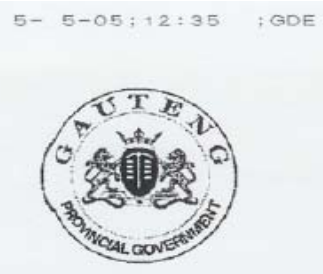

\begin{tabular}{|l|l|}
\hline Date: & 15 April 2005 \\
\hline Name of Researcher: & Stobbart Lillian \\
\hline Address of Researcher: & 13 San Chiara \\
\hline & Calderwood Road \\
\hline & Lonehill, Johannesburg \\
\hline Telephone Number: & $(011) 4658453$ \\
\hline Fax Number: & N/A \\
\hline Research Topic: & $\begin{array}{l}\text { Home-based literacy experiences of } \\
\text { congenitally deaf pre-schoolers as } \\
\text { provided by their hearing parents }\end{array}$ \\
\hline Number and type of schools: & $\begin{array}{l}\text { LSEN Schools } \\
\text { Johannesburg East \& South }\end{array}$ \\
\hline District/s/HO & \\
\hline
\end{tabular}

\section{Re: Approval in Respect of Request to Conduct Research}

This letter serves to indicate that approval is hereby granted to the above-mentioned researcher to proceed with research in respect of the study indicaled above. The onus rests with the researcher to negotiate appropriate and relevant time schedules with the school/s and/or offices involved to conduct the research. A separate copy of this letter must be presented to both the School (both Principal and SGB) and the District/Head Office Senior Manager confirming that permission has been granted for the research to be conducted.

Permission has been granted to proceed with the above study subject to the conditions listed below being met, and may be withdrawn should any of these conditions be flouted:

1. The District/Head Office Senior Manager/s concerned must be presented with a copy of this letter that would indicate that the said researcher/s has/have been granted permission from the Gauteng Department of Education to conduct the research study.

2. The District/Head Office Senior Manager/s must be approached separately, and in writing, for permission to involve District/Head Office Officials in the project.

3. A copy of this letter must be forwarded to the school principal and the chairperson of the School Governing Body (SGB) that would indicate that the researcher/s have been granted permission from the Gauteng Department of Education to conduct the research study.

$$
\text { Tel: (011) 355-0488 Fax: (011) 355-0286 }
$$


4. A letter / document that outlines the purpose of the research and the anticipated outcomes of such research must be made available to the principals, SGBs and District/Head Office Senior Managers of the schools and districts/offices concerned, respectively.

5. The Researcher will make every effort obtain the goodwill and co-operation of all the GDE officials, principals, chairpersons of the SGBs, teachers and learners involved. Persons who offer their co-operation will not receive additional remuneration from the Department while those that opt not to participate will not be penalised in any way.

6. Research may only be conducted after school hours so that the normal school programme is not interrupted. The Principal (if at a school) and/or Senior Manager (if at a districthead office) must be consulted about an appropriate time when the researcher/s may carry out their research at the sites that they manage.

7. Research may only commence from the second week of February and must be concluded before the beginning of the last quarter of the academic year.

8. Items 6 and 7 will not apply to any research effort being undertaken on behalf of the GDE. Such research will have been commissioned and be paid for by the Gauteng Department of Education.

9. It is the researcher's responsibility to obtain written parental consent of all learners that are expected to participate in the study.

10. The researcher is responsible for supplying and utilising his/her own research resources, such as stationery, photocopies, transport, faxes and telephones and should not depend on the goodwill of the institutions and/or the offices visited for supplying such resources.

11. The names of the GDE officials, schools, principals, parents, teachers and learners that participate in the study may not appear in the research report without the written consent of each of these individuals and/or organisations.

12. On completion of the study the researcher must supply the Senior Manager: Strategic Policy Development, Management \& Research Coordination with one Hard Cover bound and one Ring bound copy of the final, approved research report. The researcher would also provide the said manager with an electronic copy of the research abstract/summary and/or annotation.

13. The researcher may be expected to provide short presentations on the purpose, findings and recommendations of his/her research to both GDE officials and the schools concerned.

14. Should the researcher have been involved with research at a school and/or a district/head office level, the Senior Manager concerned must also be supplied with a brief summary of the purpose, findings and recommendations of the research study.

The Gauteng Department of Education wishes you well in this important undertaking and looks forward to examining the findings of your research study.

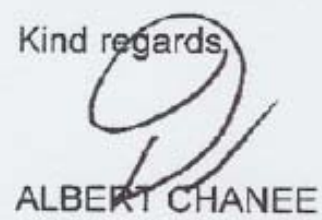

ACTING DIVISIONAL MANAGER: OFSTED

The contents of this letter has been read and understood by the researcher.

Signature of Researcher:

Date:




\section{APPENDIX H}

\section{ETHICAL CLEARANCE FROM THE UNIVERSITY OF PRETORIA}

Members:

Research Proposal and Ethics Committee

Dr P Chiroro; Dr L Davis; Prof C Delport

Dr JEH Grobler; Prof KL Harris; Prof E Krüger:

Prof B Louw (Chair); Prof D Prinsloo;

Prof G Prinsloo; Dr E Taljard; Prof H van der Mescht;

Prof $J$ van Eeden; Prof A Wessels; Mr FG Wolmarans

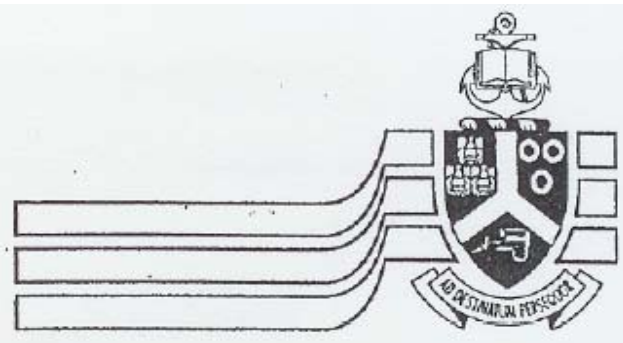

\section{University of Pretoria}

Research Proposal and Ethics Committee Faculty of Humanities

22 June 2005

Dear Professor Alant

Project:

Home-based literacy experiences of severe to profoundly deaf pre-schoolers as provided by their

Researcher: hearing parents

Supervisor:

Department:

CL Stobbart

Prof E Alant

Reference number:

CAAC

78156034

Thank you for the response to our letter and requests of 1 June 2005.

I have pleasure in informing you that the Research Proposal and Ethics Committee formally approved the above study at an ad hoc meeting held on 20 June 2005. The approval is subject to the candidate abiding by the principles and parameters set out in her application and research proposal in the actual execution of the research.

The committee requests you to convey this approval to Ms Stobbart.

We wish you success with the project.

Sincerely<smiles>CCCCC(=O)N1CCCC1</smiles>

Prof Brenda Louw

Chair: Research Proposal and Ethics Committee

Faculty of Humanities

UNIVERSITY OF PRETORIA 


\section{APPENDIX I \\ CONSENT AND INFORMATION LETTER TO SCHOOLS AND UNITS}

\begin{tabular}{|lc||}
\hline Centre for & \multicolumn{1}{|c|}{ Sentrum } \\
vir & \\
Augmentative and & Aanvullende en \\
Alternative & Alternatiewe \\
Communication & Kommunikasie \\
& \& \\
& \\
& INTERFACE \\
\hline
\end{tabular}

T-Systems Age of Innovation \& Sustainability Awards: Excellence in Innovation and Sustainability: Social National Science \& Technology Awards: Corporate Organization over the last ten years.

\section{Shirley McNaughton Award for Exemplary} Communication received from the International Society for Augmentative and Alternative Communication

1998: Rolex Award for Enterprise: Associate Laureate

1995: Education Africa Presidential Award for Special Needs

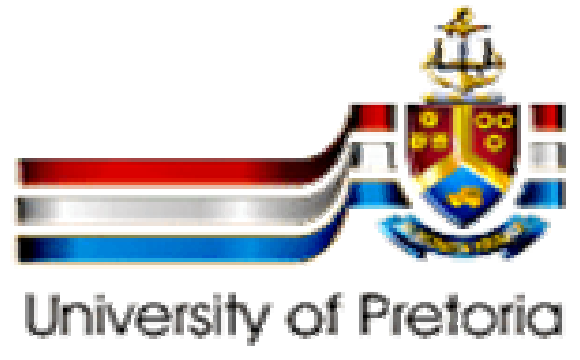

Website: http://www.up.ac.za/academic/caac Fax/Faks: (012) 420 - 4389

Tel: (012) $420-2001$

E-mail: erna.alant@up.ac.za

Faculty of Education / Fakulteit Opvoedkunde Centre for Augmentative and Alternative Communication Sentrum vir Aanvullende en Alternatiewe Kommunikasie University of Pretoria, Lynnwood Road PRETORIA, 0002

SOUTH AFRICA

9 June 2005

Details of Principal and school's address

Dear

Request for permission to conduct a research project

I am presently completing a Master's Degree in Augmentative and Alternative Communication at the University of Pretoria. In order to fulfil the requirements for this degree, I have to conduct a research project. The topic of this research is, "The home-based literacy experiences of severe to profoundly deaf pre-schoolers as provided by their hearing parents”.

The main objective of the research is to describe the early reading and writing experiences of the deaf pre-schoolers as provided by their hearing parents. This description will be based on four literacy contexts that have been identified in the literature. These contexts are:

1. The physical and functional context, which will describe the physical literacy environment surrounding the child as well as the structure and function of daily literacy activities in the home.

2. The language context, which will describe the interaction between the adult and the child during literacy activities as well as the patterns of language use. 


\section{University of Pretoria etd - Stobbart C L (2006)}

3. The affective context, which will refer to the parents' priorities regarding literacy acquisition and their expectations of literacy development.

4. The educational context, which will describe the collaboration between the home and the school in facilitating the child's literacy development.

The questionnaire is designed to elicit information relating to the above four contexts. It consists of three sections and 43 questions in total. Parents should complete the questionnaire in 45 to 60 minutes. The questionnaire has also been translated into Afrikaans to allow parents with Afrikaans as home-language to participate. It is hoped that this research will highlight the need for focus on the early literacy experiences of young deaf children, in addition to the emphasis on language acquisition.

Following from our previous telephonic discussion when you indicated your willingness to participate in the research, I hereby wish to formally request your permission to send out questionnaires to the parents of pre-schoolers currently at your school.

Regarding the selection of the pre-school children, I wish to request your permission to view the records of the children in consultation with the therapists at the school. This is to ensure that only those children with deafness in the severe to profound ranges and cognitive functioning within normal ranges are selected to participate in the research. Parents who complete the questionnaires must have normal hearing. Children must be within the 3-6 year age range.

Following the selection of children, I hope to send the letters requesting parents' participation home with the children after the July holidays, at a time that is convenient to the school. I wish to assure you that all information from the school and the parents will be treated as strictly confidential. Once the research report is complete, I will be happy to share the results with you and the parents concerned.

Please sign below to indicate that I may proceed with the research at your school and that I may view the records of the pre-school children in the presence of a therapist. A copy of the letters of consent from the Gauteng Department of Education and the University of Pretoria's Ethics Committee are attached for your information. Your willingness to participate in this research project is greatly appreciated.

Yours sincerely

Carlin Stobbart

Student

Permission to proceed with research at

Signed:

Date :
Prof Erna Alant

Supervisor

is granted. 


\section{APPENDIX $J$ \\ PARENTAL CONSENT LETTERS FOR PARTICIPATION IN THE RESEARCH}

\begin{tabular}{||ll||}
\hline Centre for & Sentrum vir \\
Augmentative and & Aanvullende en \\
Alternative & Alternatiewe \\
Communication & Kommunikasie \\
& \& \\
& \\
& INTERFACE \\
\hline
\end{tabular}

2004 T-Systems Age of Innovation \& Sustainability Awards: Excellence in Innovation and Sustainability: Social National Science \& Technology Awards: Corporate Organization over the last ten years.

2002: Shirley McNaughton Award for Exemplary Communication received from the International Society for Augmentative and Alternative Communication

1998: Rolex Award for Enterprise: Associate Laureate

1995: Education Africa Presidential Award for Special Needs

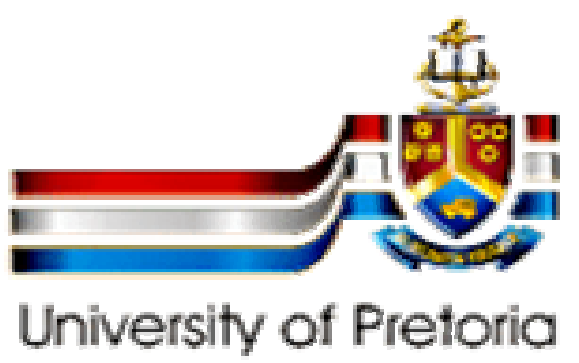

website: http://www.up.ac.za/academic/caac Fax/Faks: (012) 420 - 4389

Tel: (012) $420-2001$

E-mail: erna.alant@up.ac.za

Faculty of Education / Fakulteit Opvoedkunde

Centre for Augmentative and Alternative Communication Sentrum vir Aanvullende en Alternatiewe Kommunikasie University of Pretoria, Lynnwood Road PRETORIA, 0002 SOUTH AFRICA

Dear Parent

\section{A REQUEST FOR PARTICIPATION IN A RESEARCH PROJECT}

I am a student at the Centre for Augmentative and Alternative Communication at the University of Pretoria. For degree purposes I am conducting a research project on the early literacy experiences of young deaf children.

As a parent of a young deaf child, you are surely aware that one of the main aims in deaf education is to ensure good literacy levels for deaf learners. The present study focuses on the early home-based literacy experiences of young children. These early reading and writing experiences form the foundation for the later acquisition of more formal reading and writing skills at school.

In an attempt to describe the early literacy experiences of young deaf children, hearing parents of deaf children are requested to complete a questionnaire. The questionnaire consists of three sections and 43 questions in total. It should take about 30-45 minutes to complete. There are no right or wrong answers. Your unique experiences are of importance in the description of the children's home-based literacy experiences. 
This letter is to request your participation and valued input in this research project. Should you wish to discuss the questionnaire with me, you can contact me on 0836390930, at home on (011) 4658453, or via e-mail at carlins@tiscali.co.za. I assure you that your response will remain confidential and anonymous. Your participation is completely voluntary.

I will appreciate your participation in this research project. Please indicate your willingness to participate by completing and signing the attached consent form. You need to return this form to your child's teacher at your earliest convenience. Following your consent, I will forward the questionnaire to you via your child’s school.

Yours sincerely

Carlin Stobbart

Prof Erna Alant

Student

Supervisor

9 June 2005

Dear Parent

Please indicate your willingness to participate in this research project by completing and signing this form. Please return the form to your child's teacher at your earliest convenience.

Thank you for your cooperation.

Yours sincerely

Carlin Stobbart

I am happy to complete the questionnaire and understand that my responses will remain anonymous and confidential.

I do not wish to participate in this research. Please do not send a questionnaire.

Comments:

Signature:

Kindly provide me with your contact details.

Name:

Postal address:

Telephone numbers: 


\section{Centre for \\ vir \\ Augmentative and \\ Alternative \\ Communication \\ Alternatiewe \\ Kommunikasie \\ $\&$}

\section{INTERFACE}

T-Systems Age of Innovation \& Sustainability Awards: Excellence in Innovation and Sustainability: Social

2003 National Science \& Technology Awards: Corporate Organization over the last ten years.

2002: Shirley McNaughton Award for Exemplary Communication received from the International Society for Augmentative and Alternative Communication Rolex Award for Enterprise: Associate Laureate 1995:

Education Africa Presidential Award for Special Needs

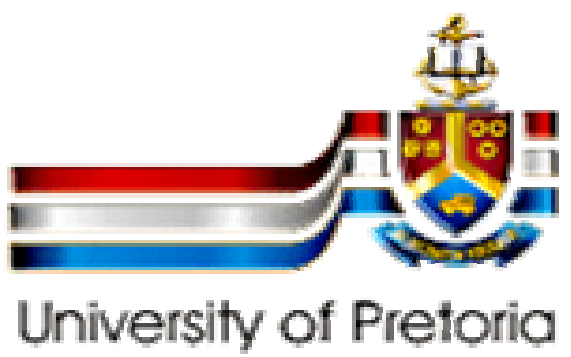

website: http://www.up.ac.za/academic/caac Fax/Faks: (012) 420 - 4389

Tel: (012) $420-2001$

E-mail: erna.alant@up.ac.za

Faculty of Education / Fakulteit Opvoedkunde

Centre for Augmentative and Alternative Communication Sentrum vir Aanvullende en Alternatiewe Kommunikasie University of Pretoria, Lynnwood Road PRETORIA, 0002 SOUTH AFRICA

9 Junie 2005

Geagte Ouer

\section{VERSOEK OM U DEELNAME AAN 'N NAVORSINGSPROJEK}

Ek is ' $\mathrm{n}$ student by die Sentrum vir Aanvullende en Alternatiewe Kommunikasie by die Universiteit van Pretoria. As deel van my studies, doen ek tans 'n navorsingsprojek wat handel oor vroee geletterdheid in jong dowe kinders.

As ' $n$ ouer van 'n dowe kind, is u sekerlik bewus daarvan dat een van die hoof doelstellings van onderwys vir dowes is om goeie vaardigheid in geletterdheid te ontwikkel. Hierdie navorsing fokus op jong dowe kinders se vroee ervarings in geletterdheid in die tuissituasie. Die vroee ervarings vorm die grondslag vir ontwikkeling van formele lees- en skryfvaardighede op skool.

Ten einde vroee blootstelling aan geletterdheid in die tuissituasie te beskryf, word horende ouers van dowe kinders gevra om ' $n$ vraelys voltooi. Die vraelys bestaan uit drie afdelings en 43 vrae. Dit behoort 30-45 minute te neem om die vraelys te voltooi. Daar is geen korrekte of verkeerde antwoorde nie. U unieke ervarings is van belang in die beskrywing van die kinders se vroee lees- en skryfervaringe.

Hierdie brief is on u deelname aan die navorsingsprojek te versoek. Sou u graag eers die vraelys met my wil bespreek, kan u my kontak by 0836390930, of tuis by (011) 4658453, of per e-pos by carlins@tiscali.co.za. Ek verseker u dat u antwoorde te alle tye vertroulik en anoniem sal bly. U deelname is heeltemal vrywillig. 
U deelname aan die navorsing sal baie waardeer word. Dui asseblief u gewilligheid tot deelname aan deur die volgende toestemmingsvorm in te vul. Stuur asseblief die voltooide vorm terug na u kind se onderwyseres. Sodra ek u gewilligheid tot deelname aan die projek ontvang, sal ek die vraelys met u kind huistoe stuur.

Vriendelike groete

Carlin Stobbart

Student

9 Junie 2005
Prof Erna Alant

Studieleier

(2005

\section{Geagte Ouer}

Dui asseblief u gewilligheid om aan hierdie navorsingsprojek deel te neem aan deur die volgende vorm in te vul en te teken. Stuur asseblief hierdie vorm so gou as moontlik terug na u kind se skool.

U samewerking sal baie waardeer word.

Vriendelike Groete

Carlin Stobbart

Ek is bereid om die vraelys te voltooi. Ek verstaan dat my antwoorde vertroulik en anoniem sal bly.

Ek verkies om nie aan die navorsingsprojek deel te neem nie. Moet asseblief nie ' $n$ vraelys stuur nie.

Aanmerkings:

Handtekening:

Verskaf asseblief u kontak nommers:

Naam:

Posadres:

Telefoon: 


\section{APPENDIX K \\ QUESTIONNAIRE: CATEGORIES FOR OPEN QUESTIONS}

\section{SECTION A}

\section{Question 1}

Relationship to the deaf child

3 = Female relative (aunt / grandmother / adult sister)

4 = Male relative (uncle / grandfather / adult brother)

$8=$ Both parents completed the questionnaire

Question 7

Home Languages

7= Other European languages

8 = Other African languages (Setswana, Tsonga, Venda)

\section{Question 8}

\section{Other languages used at home}

7 = Other European languages (Polish)

$8=$ Other African languages

$9=$ No other languages

\section{SECTION C}

\section{Question 1}

Child's favourite activities other than what is given in the list

$1=$ Ballet $/$ Dancing lessons

2 = Art-related activities

$3=$ Helping other people

$4=$ Computer

$5=$ Puzzles

\section{Question 3}

A description of the family's reading activities

1 = Recreational reading (novels, magazines) by one / both parents / older siblings

$2=$ Work-related reading

3 =Information reading (newspapers)

$4=$ School related reading matter (siblings)

$5=$ Read stories to other hearing siblings

6 = Computer related reading (internet)

\section{Question 4}

Other printed material excluding what is in the list

$1=$ Puzzles and colouring in books 


\section{University of Pretoria etd - Stobbart C L (2006)}

\section{Question 5}

\section{What is the child's favourite printed material?}

$1=$ Children's story books

2 = Magazines (Car; Huisgenoot; TV Guides; Cutting out from Magazines)

3 = Contemporary reading material (Disney, Pooh Bear, Barney)

4 = Children's picture books (word books)

$5=$ Colouring-in books

$6=$ Children's Bible

$7=$ Own library books

$8=$ Animal books

\section{Question 6}

\section{How does the child show interest in reading activities?}

1 = Child asks questions (shows interest by asking questions / parent shows pictures, child asks questions and tries to tell the story / the child tries to understand the story / uses pictures to teach new vocabulary)

$2=$ Child shows pictures to the parent (uses the pictures communicatively / relates pictures to stories from school)

3 = Shows enthusiasm for reading (fetches books to be read / has favourite stories / looks at books voluntarily / chooses own books and magazines and asks for it to be read / asks what the next story will be / eager to look at books / will sit still and listen to a story / always looking at books and writing in them/ wants to read every day).

4 = Incorporates reading in fantasy play (lines dolls up and show pictures as if to read)

5 = Enjoys book-related outings (loves going to the library / loves going to the bookshop)

$6=$ Pretends to read

7 = Inquisitive about reading (wants to know what adults read / wants to join in when siblings read or do homework / wants to read with friends).

8 = Shows awareness of the alphabet (tries to spell the sounds in the words).

\section{Question 8}

What are the child's favourite storybooks?

1 = Simple childrens story books (related to the lives of children, not fairy tales. Books about babies, Sam starts school, Alfiebooks).

2 = Picture books (category books, vocab type books, colours and shapes, colourful pictures, theme books - home, first 1000 English words and comic books).

$3=$ Number books.

4 = Fairy tales and fantasy stories (Rapunzel, Snow White and Seven Dwarfs, Little Mermaid, Cinderella, Show Day Fame, Teddy and the Fire Brigade, The Gingerbread Man).

5 = Animal Books (Animal Kingdom, Theodore Mouse, Animal Homes).

$6=$ Alphabet books.

7 = Activity books (fun activities, colouring in, crafts, puzzle books).

8 = Magazines (Huisgenoot, Bona, True Love).

$9=$ Rhyming books (Dr Seuss).

\section{Question 10}

\section{Other times that the parent reads to the child}

$1=$ Upon the child's request, irrespective of a set daily time.

2 = Over weekends.

3 = When time is available / when we have time e.g. kitchen time or TV time. 


\section{Question 12}

When you read to your child, what types of books do you read? Categories for other than what was given in the list

1 = Non-fiction type reading matter (Sunday Times Read Right).

2 = Comic-type books (Garfield, Beeno).

\section{Question 13}

What does the child usually do during reading?

$1=$ Still developing attention to reading

2 = Contributes to the reading / talks about the pictures i.e. colour, shapes, number

\section{Question 14}

How does the child usually communicate with the parent during reading activities?

$1=$ The child is quiet / there is no communication from the child.

\section{Question 15}

How is the child positioned during reading?

$1=$ On the floor.

\section{Question 16}

What does the parent usually do when reading to the child?

1 = Adjust the texts while reading rather than reading the exact words (to prevent boredom / inattentiveness).

$2=$ Tells the story in own words relating to the pictures.

\section{Question 17}

Does the child enjoy reading? Explain behaviours

1 = Shows good concentration during reading sessions / is very involved during reading

$2=$ Enjoys the individual attention / enjoys the time shared with the parent

3 = Child initiates reading / enjoys looking through books with adults / will bring books for the adult to read.

4 = Child is excited about reading / shows an eagerness for reading related activities / child participates spontaneously.

5 = Child incorporates Sign Language into reading / parent reads the story and child repeats the story to the reader in Sign Language (this is probably one way parents learn SL from their children).

6 = Independent interaction with books. Child “reads' alone, parent does not know if the child enjoys reading activities because the child cannot talk.

7 = Active participation in story reading / Child answers and ask questions related to the pictures / points to the pictures.

$8=$ The child is sad when story time is over / asks for more stories to be read.

9 = Child not at all attentive during reading / loses interest very quickly.

\section{Question 18}

Is writing something that the family enjoys. For a more negative reply:

1 = Only write what is needed / mother only writes her own things / writing is something that has to be done 


\section{Question 19}

Describe the family's writing and drawing activities

The first section to this question: Other:

$1=$ No specific time.

The second section to this question

$1=$ Parents write letters / e-mail / computer.

2 = Incidental writing (notes, shopping lists, complete forms).

$3=$ Parents do work related writing.

4 = Siblings do school related writing.

5 = Activities which involve the deaf child by the family or extended family. Drawing / writing / painting activities whenever the deaf child wants it / drawing members of the family.

$6=$ Writing names and letters of the alphabet on the child's request.

7 = Drawing on a blackboard with the deaf child.

8 = Siblings draw and deaf child observes.

$9=$ Parents are artists.

\section{Question 20}

Writing and drawing materials other than what is given on the list

$1=$ Colouring in books

\section{Question 21}

How often does the child use writing and drawing materials / other times not specified:

5 = When the child is at home / this applies to children who are in weekly boarding

\section{Question 22}

\section{How does the child show interest in writing and drawing activities?}

$1=$ Enjoys cutting activities.

2 = Copying / tracing / stencilling / copying of the alphabet.

$3=$ Colouring in.

$4=$ Watches when adults write or draw.

5 = Child initiated: will bring paper and pen and ask for writing and drawing / brings chalk and chalkboard and asks for drawing / asks brother and sister to draw / eagerness to write / when sees paper and pens wants to write / asks for writing and drawing when siblings do homework / asks for pen and paper.

6 = A favourite pastime: spends a lot of time doing these activities / never wants to pack it away / drawing all the time also in inappropriate places.

7 = Draws independently. Child enjoys drawing on his own / draws stick figures of the family / loves drawing pictures.

8 = Incorporates writing in fantasy play. (Pretends to be a waitress and takes orders by scribbling on a piece of paper).

\section{Question 23}

When child is involved in reading and writing, who else participates? In the other category:

$1=$ Cousins

2 = Aunts and uncles

\section{Question 24}

Who initiates these activities? In the other category:

$1=$ Cousins 


\section{University of Pretoria etd - Stobbart C L (2006)}

\section{Question 26}

Why are these aspects relating to language, reading, writing and communication important to the parent at the present time? 1 = Happy and well-adjusted child

- $\quad$ Parents want child to live a happy well-adjusted life

- $\quad$ The child is important

\section{$2=$ Preparation of child to cope in wider world}

- $\quad$ Child must be able to cope with obstacles

- $\quad$ To prepare child to cope in the wider world

- So that child can help herself in a normal environment

- $\quad$ Child must have knowledge of the hearing world

- Child must have knowledge of many different things around him so that he can learn for the future

- The child must develop speech and language so that he can function independently in the hearing world

- The child must be able to succeed in the hearing world

- $\quad$ The child must acquire these skills so that he can be mainstreamed

- $\quad$ To be able to make her needs known in hearing world

\section{$3=$ Communication is important}

- So that there is good communication within the family

- Good communication will ease frustration in getting messages across

- To communicate like hearing people

- $\quad$ The ability to communicate well

- To start communicating as soon as possible so that he can speak to others

\section{4 = Relationships}

- To enable the child to form meaningful relationships with family and friends.

\section{5 = Develop to full potential}

- So that the child can develop to his full potential in all the areas concerned.

- $\quad$ So that the child can use his cochlear implant to its maximum potential.

- $\quad$ The child is at the right threshold now to develop these skills

\section{Question 30}

\section{Comments parents wish to add}

\section{1 = Awareness of parent's role in reading}

- $\quad$ Parent is aware that more time and effort is required when reading to the deaf child. Sometimes takes for granted that the deaf child is not "normal and needs to have more time set aside.

- As a parent, I do not spend enough time reading to my deaf child and other children. I have been quite slack in reading to my deaf child.

\section{2 = The role of Sign Language in reading}

- $\quad$ There is interaction between the parent and the child using speech and sign relating to the stories being read

- $\quad$ Parents prefer the child not to use Sign Language as other family members will not understand the child and will not be able to attend SL classes

- $\quad$ Parents want the child to talk.

\section{3 = Parental Needs}

- $\quad$ Parent has difficulty in finding appropriate books

- $\quad$ Parent needs more knowledge about Sign Language and deafness

- Money for appropriate reading and writing materials is needed

- $\quad$ Parent needs more knowledge about how to read to the deaf child as well as on communication methods 
- $\quad$ Parents would like to see more facilities available specific for the deaf e.g. videos with SL for parents/ SL video stories / books with SL.

- $\quad$ Local libraries have very little and what they have is often out-dated. More awareness of deafness?

4 = Parent's views on benefits of reading

- Reading is crucial for deaf children as it can provide the "gains" that are "missed" due to the deafness

- It is critically important for the deaf to read / enormous benefit, pleasure and satisfaction to be gained by learning to read

- When reading at home the child can relate the stories to the work that was done at school

- Books allow the child to choose own areas of interest e.g. Sam goes to school

$\mathbf{5}=$ Role of Reading in communication and language learning

- $\quad$ Books are a good way to increase vocabulary and help the child to ask for everyday things. It gives an increased understanding of other aspects of language and communication

- Increased interest in books after hearing aids were fitted. Now becoming more interested in stories, which are ageappropriate. General improvements since hearing aids were fitted.

\section{$6=$ Role of school in reading}

- $\quad$ Parents have also received guidance regarding reading and books from the Speech Therapist

- Parent sets her own reading targets for the child as the school has always encouraged reading with the child to enhance vocabulary and communication skills

- $\quad$ School helps parent to be more positive and committed to the child's development. 


\section{APPENDIX L \\ OUTLINE FOR INTEGRATION OF QUESTIONS INTO THE DISCUSSION \\ OF THE RESULTS}

\begin{tabular}{|c|c|c|}
\hline CHAPTER 4: TOPIC & $\begin{array}{l}\text { QUSTIONS FROM SECTION C } \\
\text { PRESENTED IN THE DISCUSSION }\end{array}$ & QUESTION TYPES \\
\hline \multicolumn{3}{|l|}{$\begin{array}{l}\text { 4.2 PHYSICAL AND } \\
\text { FUNCTIONAL CONTEXT }\end{array}$} \\
\hline $\begin{array}{l}\text { 4.2.1 Reading and writing as } \\
\text { favourite activity }\end{array}$ & $\begin{array}{l}\text { Q1: Favourite activity } \\
\text { Q18: Child's enjoyment of reading } \\
\text { Q6:Interest in reading } \\
\text { Q22: Interest in writing }\end{array}$ & $\begin{array}{l}\text { Closed question } \\
\text { Yes/no question with explanation } \\
\text { Scaled question with description } \\
\text { requested } \\
\text { Scaled question with description } \\
\text { requested }\end{array}$ \\
\hline $\begin{array}{l}\text { 4.2.2 Nature of home reading } \\
\text { and writing }\end{array}$ & $\begin{array}{l}\text { Q2: Family's interest in reading } \\
\text { Q18: Family's interest in writing/drawing } \\
\text { Q3: Family's frequency of reading } \\
\text { Q19: Family’s frequency of writing } \\
\text { Q4: Reading material in the home } \\
\text { Q20: Writing material in the home }\end{array}$ & $\begin{array}{l}\text { Scaled question } \\
\text { Dichotomous question } \\
\text { Multiple-choice question } \\
\text { Multiple-choice question } \\
\text { Closed question } \\
\text { Closed question } \\
\end{array}$ \\
\hline $\begin{array}{l}\text { 4.2.3 Deaf child's literacy } \\
\text { experiences }\end{array}$ & $\begin{array}{l}\text { Q7: Book ownership } \\
\text { Q10: Preferred story reading times } \\
\text { Q8: Deaf child's favourite books } \\
\text { Q12: Types of books parents read to their } \\
\text { deaf children } \\
\text { Q9: Deaf child's participation in book- } \\
\text { related activities. }\end{array}$ & $\begin{array}{l}\text { Dichotomous question with } \\
\text { clarification } \\
\text { Multiple-choice question } \\
\text { Open-ended question } \\
\text { Closed question } \\
\text { Statement type question } \\
\end{array}$ \\
\hline $\begin{array}{l}\text { 4.2.4 Frequency of } \\
\text { engagement in reading and } \\
\text { writing activities. }\end{array}$ & $\begin{array}{l}\text { Q5: Deaf child's use of printed material } \\
\text { Q21: Deaf child's participation in writing } \\
\text { activities } \\
\text { Q11: Frequency of story reading activities }\end{array}$ & $\begin{array}{l}\text { Multiple-choice question } \\
\text { Multiple-choice question } \\
\text { Statement type question. }\end{array}$ \\
\hline $\begin{array}{l}\text { 4.3 LANGUAGE CONTEXT } \\
\text { 4.3.1 The deaf child's } \\
\text { behaviour and } \\
\text { communication during story } \\
\text { reading activities }\end{array}$ & $\begin{array}{l}\text { Q13: Deaf child's behaviour during story } \\
\text { reading } \\
\text { Q14: Deaf child's communication during } \\
\text { story reading } \\
\text { Q15: Positioning during story reading }\end{array}$ & $\begin{array}{l}\text { Closed question } \\
\text { Closed question } \\
\text { Closed question }\end{array}$ \\
\hline $\begin{array}{l}\text { 4.3.2 Hearing parents' role } \\
\text { during story reading activities }\end{array}$ & Q16: Parent's role in story reading activities & Closed question \\
\hline $\begin{array}{l}\text { 4.3.3 The role of other family } \\
\text { members in the literacy } \\
\text { activities of deaf children }\end{array}$ & $\begin{array}{l}\text { Q23 and Q24: Family's participation in } \\
\text { writing and drawing activities } \\
\text { Q25: Sibling's participation in literacy } \\
\text { related activities }\end{array}$ & $\begin{array}{l}\text { One dichotomous question and one } \\
\text { closed question } \\
\text { Closed question }\end{array}$ \\
\hline
\end{tabular}




\begin{tabular}{|l|l|l|}
\hline $\begin{array}{l}\text { 4.4 AFFECTIVE CONTEXT } \\
\text { aspects of their deaf } \\
\text { children's development }\end{array}$ & $\begin{array}{l}\text { Q26: Parental priorities regarding the deaf } \\
\text { child's development }\end{array}$ & Rating-type question \\
\hline $\begin{array}{l}\text { 4.4.2 Parents' allocation of } \\
\text { responsibility in their } \\
\text { children's literacy } \\
\text { development }\end{array}$ & $\begin{array}{l}\text { Q27: Parental allocation of responsibility } \\
\text { regarding the teaching of literacy skills }\end{array}$ & Rating-type question \\
\hline $\begin{array}{l}\text { 4.5 EDUCATIONAL } \\
\text { CONTEXT }\end{array}$ & $\begin{array}{l}\text { Q28: Parents experiences in reading to their } \\
\text { deaf children }\end{array}$ & Statement-type question \\
$\begin{array}{l}\text { 4.5.1 Parents' experiences in } \\
\text { reading to their deaf children }\end{array}$ & $\begin{array}{l}\text { Q29: Literacy-related services provided by } \\
\text { the school and parents needs in this regard }\end{array}$ & Statement-type question \\
\hline $\begin{array}{l}\text { 4.5.2 Parents' experiences of } \\
\text { support received from their } \\
\text { children's schools }\end{array}$ & $\begin{array}{l}\text { Parents' comments at the end of the } \\
\text { questionnaire. }\end{array}$ & $\begin{array}{l}\text { These observations were integrated } \\
\text { into the relevant questions. }\end{array}$ \\
\hline GENERAL
\end{tabular}




\section{APPENDIX M \\ DETAILED RESULTS OBTAINED FOR QUESTION 11}

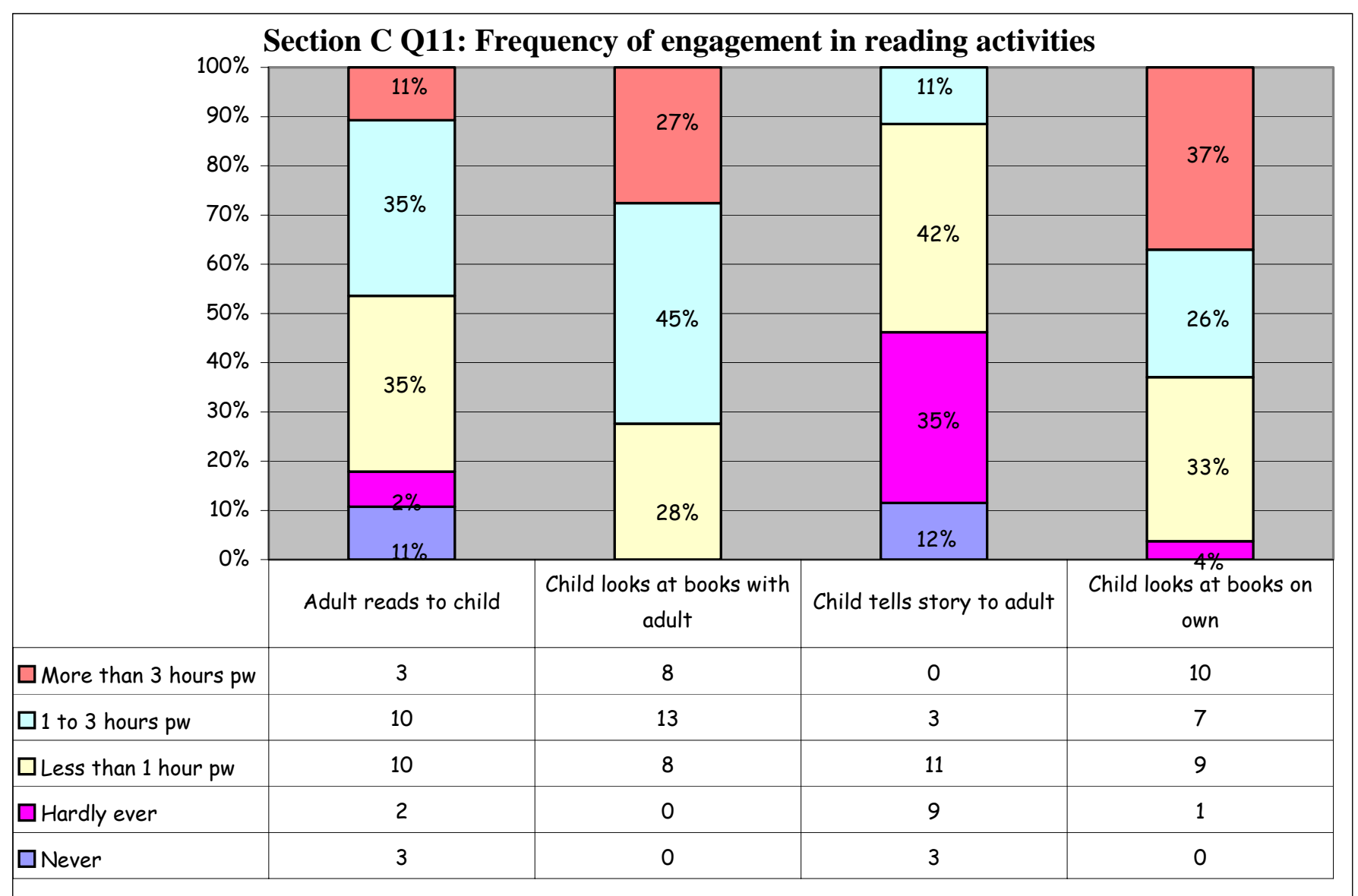

For the purpose of comparison between these different questions the information provided was condensed as follows:

- More than 3 hours per week and 1-3 hours per week regarded as: FREQUENTLY

- Less than an hour per week, hardly ever and never were regarded as: RARELY 


\section{APPENDIX N \\ STATISTICAL ANALYSIS}

4.2.1 Reading and writing as favourite activities (as per text):

\section{Favourite activities}

Fisher's Exact Test for small samples was utilised to determine a possible relationship between children looking at books on their own as a favourite activity and children reading with an adult as a favourite activity.

VV29 Reading with an adult is a favourite activity

VV28 Looking at books on their own is a favourite activity

\begin{tabular}{|c|c|c|c|}
\hline $\begin{array}{l}\text { Frequency } \\
\text { Percentage }\end{array}$ & NO & YES & Totals \\
\hline NO & 1 & 12 & 13 \\
& 3.45 & 41.38 & 44.83 \\
\hline YES & 0 & 16 & 16 \\
& 0.00 & 55.17 & 55.17 \\
\hline Totals & 1 & 28 & 29 \\
& 3.45 & 96.55 & 100 \\
\hline
\end{tabular}

\section{Fisher's Exact Test:}

Cell $(1,1)$ Frequency (F) 1

Two-sided $\mathrm{Pr}<=$ P 0.4483

Left-sided $\operatorname{Pr}<=$ F 1.0000

Right-sided Pr $>$ = F 0.4483
Table Probability (P) 0.4483

Sample size $=29$

\section{Interest in reading and writing}

Fisher's Exact Test was utilised to determine a possible association between levels of interest in reading and writing/drawing.

VV61 Child's interest in reading activities

VV148 Child's interest in writing/drawing activities

\begin{tabular}{|c|c|c|c|}
\hline $\begin{array}{l}\text { Frequency } \\
\text { Percentage }\end{array}$ & LOW & HIGH & Totals \\
\hline LOW & 1 & 7 & 8 \\
& 3.45 & 24.14 & 27.59 \\
\hline HIGH & 1 & 20 & 21 \\
& 3.45 & 68.97 & 72.41 \\
\hline Totals & 2 & 27 & 29 \\
& 6.905 & 93.10 & 100 \\
\hline
\end{tabular}

Fisher's Exact Test:

Cell $(1,1)$ Frequency (F) 1

Left-sided $\operatorname{Pr}<=$ F 0.9310

Right-sided Pr $>$ = F 0.4828

Table Probability (P) 0.4138
Two-sided $\mathrm{Pr}<=$ P 0.4828

Sample size $=29$ 
4.2.4 The deaf child's engagement in reading and writing activities (as per text):

Fisher's Exact Test was utilised to determine whether frequent engagement in reading is associated with frequent engagement in writing and drawing.

VV56 How often does the child use reading material

VV147 How often does the child use writing material

\begin{tabular}{|c|c|c|c|}
\hline $\begin{array}{l}\text { Frequency } \\
\text { Percentage }\end{array}$ & RARELY & FREQUENTLY & Totals \\
\hline RARELY & 31 & 6 & 9 \\
& 10.71 & 21.43 & 32.14 \\
\hline FREQUENTLY & 3 & 16 & 19 \\
& 10.71 & 57.14 & 67.86 \\
\hline Totals & 6 & 22 & 28 \\
& 21.43 & 78.57 & 100 \\
\hline
\end{tabular}

\section{Fisher's Exact Test:}

Cell $(1,1)$ Frequency (F) 3

Two-sided $\operatorname{Pr}<=$ P 0.9362

Left-sided $\operatorname{Pr}<=$ F 0.2798

Right-sided Pr $>$ = F 0.2161
Table Probability (P) 0.3518

Sample size $=28$

Frequency missing $=1$ 